Prepared in cooperation with Ohio Water Development Authority and City of Delphos, Ohio

\title{
Quantifying Viruses and Bacteria in Wastewater-Results, Interpretation Methods, and Quality Control
}

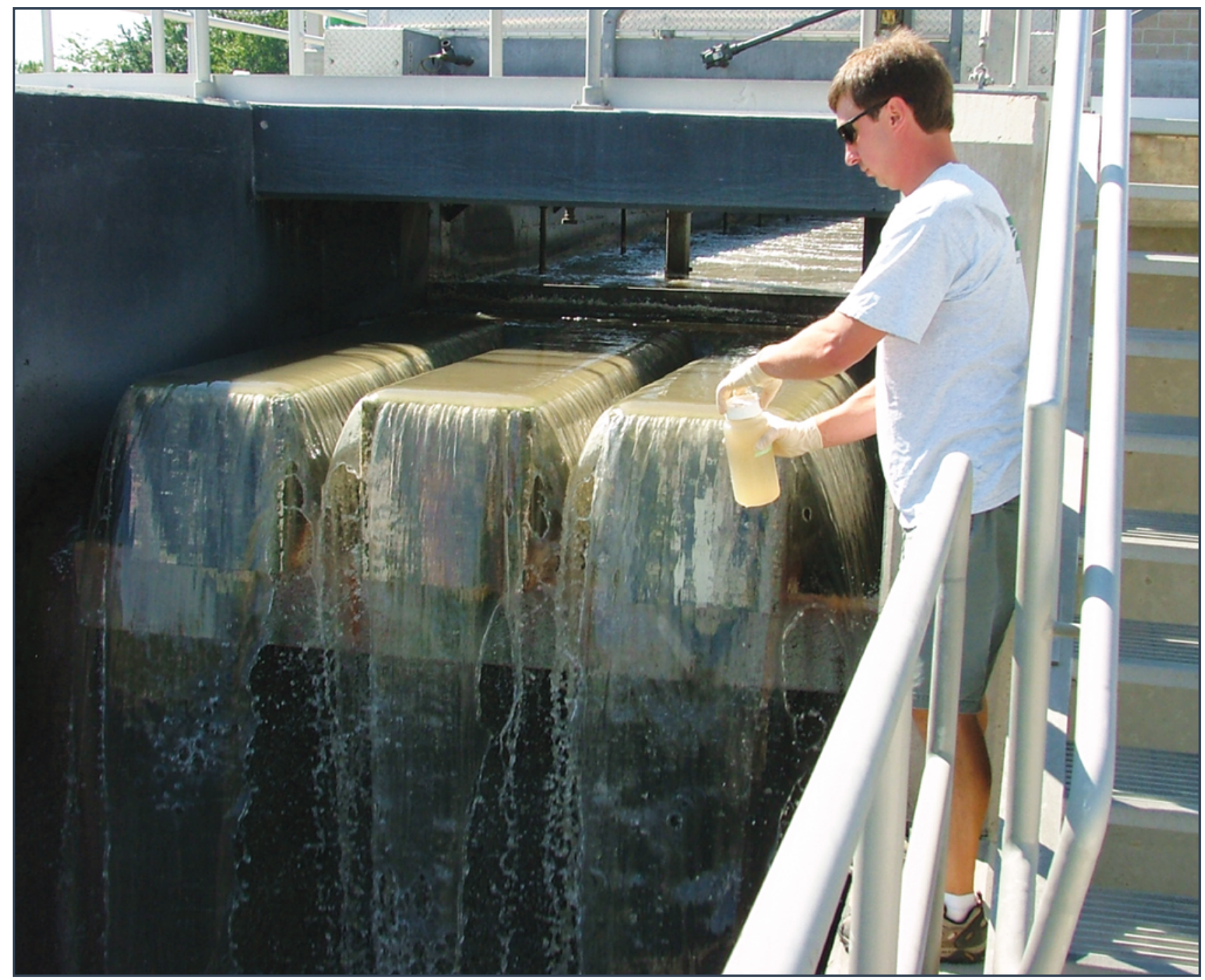

Scientific Investigations Report 2011-5150 
Cover: Report coauthor Brian Mailot collecting a post-preliminary wastewater sample at one of the study sites. (Photograph by Donna Francy, U.S. Geological Survey.) 


\section{Quantifying Viruses and Bacteria in Wastewater-Results, Interpretation Methods, and Quality Control}

By Donna S. Francy, Erin A. Stelzer, Rebecca N. Bushon, Amie M.G. Brady, Brian E. Mailot, Susan K. Spencer, Mark A. Borchardt, Ashley G. Elber, Kimberly R. Riddell, and Terry M. Gellner

Prepared in cooperation with Ohio Water Development Authority and City of Delphos, Ohio

Scientific Investigations Report 2011-5150 


\title{
U.S. Department of the Interior \\ KEN SALAZAR, Secretary
}

\author{
U.S. Geological Survey \\ Marcia K. McNutt, Director
}

U.S. Geological Survey, Reston, Virginia: 2011

For more information on the USGS - the Federal source for science about the Earth, its natural and living resources, natural hazards, and the environment, visit http://www.usgs.gov or call 1-888-ASK-USGS.

For an overview of USGS information products, including maps, imagery, and publications, visit http://www.usgs.gov/pubprod

To order this and other USGS information products, visit http://store.usgs.gov

Any use of trade, product, or firm names is for descriptive purposes only and does not imply endorsement by the U.S. Government.

Although this report is in the public domain, permission must be secured from the individual copyright owners to reproduce any copyrighted materials contained within this report.

Suggested citation:

Francy, D.S., Stelzer, E.A., Bushon, R.N., Brady, A.M.G., Mailot, B.E., Spencer, S.K., Borchardt, M.A., Elber, A.G., Riddell, K.R., and Gellner, T.M., 2011, Quantifying viruses and bacteria in wastewater-Results, interpretation methods, and quality control: U.S. Geological Survey Scientific Investigations Report 2011-5150, 44 p. 


\section{Acknowledgments}

We gratefully acknowledge the wastewater-treatment operators and managers for granting access to their plants, providing advice on sampling locations, and providing in-kind services during sampling. In addition to the cooperating agencies, Ohio Environmental Protection Agency (OEPA) and the U.S. Environmental Protection Agency (USEPA) provided in-kind services, and Kubota and Ovivo provided financial support for this study. We thank Stefan Wuertz (University of California, Davis) for help with quantifying viruses and Fu-Chih Hsu (Scientific Methods, Granger, Ind.) for providing reagents and advice on the EasyPhage method. We also thank the peer-review team for their help and advice throughout the study: Paul Novak and Mike McCullough (OEPA), Mark Meckes (USEPA), Jim Porteous and Douglas Bucher (Ovivo), and Minoru Fijitani (Kubota Membrane USA).

Finally, we thank two U.S. Geological Survey colleagues: Hon Ip (USGS, National Wildlife Health Center, Madison, Wis.), for advice on interpreting virus data and manuscript review; and Sandra Embrey (USGS Washington Water Science Center), for manuscript review. 


\section{Contents}

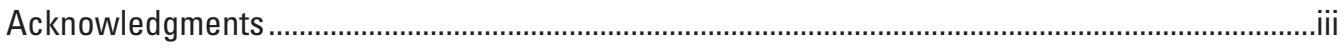

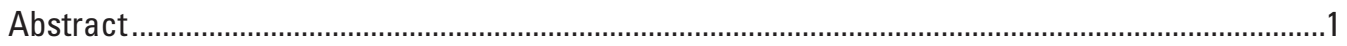

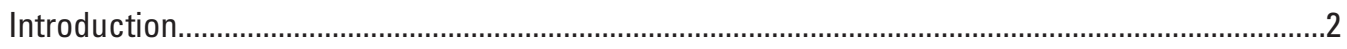

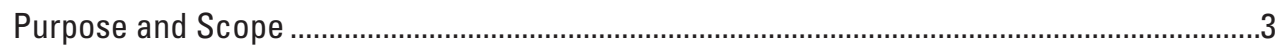

Enteric Viruses and Microbiological Indicators of Fecal Contamination...................................3

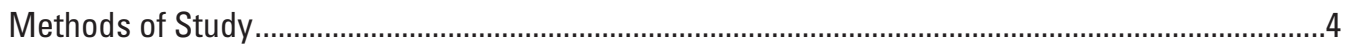

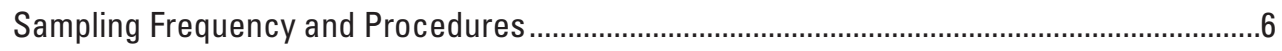

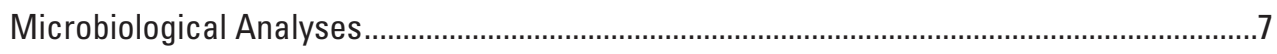

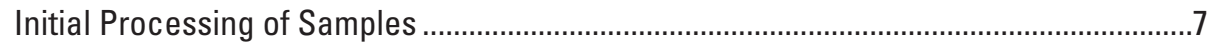

Enteric Viruses by Cell Culture ........................................................................................

DNA Extraction and Enteric Viruses by qPCR or qRT-PCR ...............................................8

Standard Curves for Enteric Viruses by qPCR or qRT-PCR .............................................8

Assay Limits of Quantification and Sample Reporting Limits for Enteric Viruses by qPCR, qRT-PCR, and Cell Culture .....................................................................

Indicator Bacteria and Coliphage ..........................................................................11

Quality Assurance and Quality Control ...................................................................................11

Indicator Bacteria and Coliphage ................................................................................. 12

Enteric Viruses .................................................................................................................... 12

Indicator Bacteria, Coliphage, and Viruses in Wastewater ..........................................................12

Enumeration Considerations for Enteric Viruses by qPCR and qRT-PCR ................................12

Quality-Control Considerations for Interpreting Bacterial-Indicator, Coliphage, and Enteric-Virus Data ............................................................................................. 17

Quality-Control Samples for Bacterial Indicators and Coliphage ...................................17

Quality-Control Samples for Enteric Viruses................................................................19

Concentrations of Bacterial Indicators and Coliphage in Wastewater....................................21

Concentrations of Enteric Viruses in Wastewater ..............................................................27

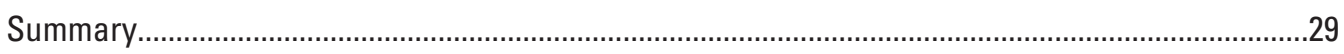

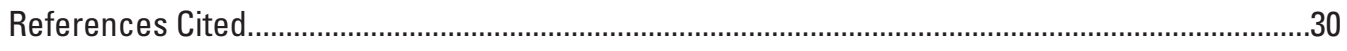

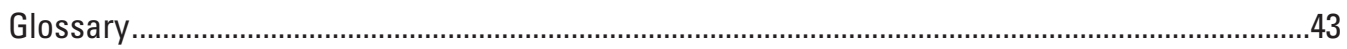




\section{Figures}

1. Schematic showing processes involved in wastewater treatment for conventional and Membrane bioreactors (MBR) facilities, and sampling points for the 2008-10 study.

2. Photograph showing equipment setup for filtering wastewater samples for enteric viruses...

3. Schematic showing determination of effective final concentrated sample volumes (FCSVs) for quantitative polymerase chain reaction (qPCR) for adenovirus or quantitative reverse transcriptase PCR (qRT-PCR) for enterovirus or norovirus $\mathrm{GI}$

4. Graphs showing quality-control replicate samples for concentrations in wastewater. $A$, bacterial indicators. $B$, coliphage.

5. Graphs showing concentrations found by use of the single agar layer and EasyPhage methods in wastewater samples, 2008. A, F-specific.

$B$, somatic coliphage.

6. Graph showing quality-control replicate samples for concentrations of viruses in wastewater, 2008-10.

7A. Graphs showing concentrations in wastewater samples, 2008-10: Escherichia coli.

7B. Graphs showing concentrations in wastewater samples, 2008-10: enterococci.

7C. Graphs showing concentrations in wastewater samples, 2008-10: fecal coliforms..

7D. Graphs showing concentrations in wastewater samples, 2008-10: somatic coliphage

7E. Graphs showing concentrations in wastewater samples, 2008-10:

F-specific coliphage 


\section{Tables}

1. Membrane bioreactor (MBR) and conventional wastewater-treatment plants, 2008-10. $\ldots 4$

2. Primers and probes for enteric viruses .......................................................................

3. Water-quality, bacterial indicator, and coliphage results from wastewater samples, 2008-10

4. Virus concentrations in wastewater samples, 2008-10 ..................................................38

5. Quality-control equipment and field-blank data for bacterial indicators, coliphage, and viruses in wastewater, 2008-10

6. Quality-control concurrent replicate data for bacterial indicators and coliphage in wastewater, 2008-10

7. Quality-control method test samples for coliphage in wastewater, 2008-10.

8. Quality-control concurrent replicate data for enteric viruses in wastewater, 2008-10.

9. Performance characteristics of quantitative polymerase chain reaction ( $\mathrm{PPCR}$ ) and reverse transcriptase $\mathrm{qPCR}$ (qRT-PCR) standard curves for each assay

10. Summary statistics for viruses by quantitative polymerase chain reaction ( $q P C R$ ) and reverse transcriptase qPCR ( $q R T-P C R$ ) and cell culture in wastewater samples, 2008-10. 


\section{Conversion Factors and Abbreviated Water Quality Units}

\begin{tabular}{|c|c|c|}
\hline Multiply & By & To obtain \\
\hline \multicolumn{3}{|c|}{ Length } \\
\hline millimeter (mm) & 0.03937 & inch (in) \\
\hline micrometer $(\mu \mathrm{m})$ & 1,000 & millimeter $(\mathrm{mm})$ \\
\hline \multicolumn{3}{|c|}{ Volume } \\
\hline liter (L) & 0.2642 & gallon (gal) \\
\hline milliliter (mL) & 0.06102 & cubic inch $\left(\right.$ in $\left.^{3}\right)$ \\
\hline microliter $(\mu \mathrm{L})$ & 1,000 & milliliter $(\mathrm{mL})$ \\
\hline \multicolumn{3}{|c|}{ Flow rate } \\
\hline million gallons per day (Mgal/d) & 0.04381 & cubic meter per second $\left(\mathrm{m}^{3} / \mathrm{s}\right)$ \\
\hline \multicolumn{3}{|c|}{ Mass } \\
\hline $\operatorname{gram}(\mathrm{g})$ & 0.03527 & ounce, avoirdupois (oz) \\
\hline
\end{tabular}

Temperature in degrees Celsius $\left({ }^{\circ} \mathrm{C}\right)$ may be converted to degrees Fahrenheit $\left({ }^{\circ} \mathrm{F}\right)$ as follows:

${ }^{\circ} \mathrm{F}=\left(1.8 \times{ }^{\circ} \mathrm{C}\right)+32$

Concentrations of bacterial indicators are given in colony-forming units per 100 milliliters (CFU/100 mL).

Concentrations of viruses are given in genomic copies per liter (gc/L).

Concentrations of coliphage are given in plaque-forming units per 100 milliliters (PFU/100 mL).

Specific conductance is given in microsiemens per centimeter at 25 degrees Celsius $\left(\mu \mathrm{S} / \mathrm{cm}\right.$ at $\left.25^{\circ} \mathrm{C}\right)$. 



\title{
Quantifying Viruses and Bacteria in Wastewater- Results, Interpretation Methods, and Quality Control
}

\author{
By Donna S. Francy, ${ }^{1}$ Erin A. Stelzer, ${ }^{1}$ Rebecca N. Bushon, ${ }^{1}$ Amie M.G. Brady, ${ }^{1}$ Brian E. Mailot, ${ }^{1}$ Susan K. \\ Spencer, ${ }^{2}$ Mark A. Borchardt, ${ }^{3}$ Ashley G. Elber ${ }^{4}$ Kimberly R. Riddell, ${ }^{5}$ and Terry M. Gellner ${ }^{6}$
}

\section{Abstract}

Membrane bioreactors (MBR), used for wastewater treatment in Ohio and elsewhere in the United States, have pore sizes small enough to theoretically reduce concentrations of protozoa and bacteria, but not viruses. Sampling for viruses in wastewater is seldom done and not required. Instead, the bacterial indicators Escherichia coli (E. coli) and fecal coliforms are the required microbial measures of effluents for wastewater-discharge permits. Information is needed on the effectiveness of MBRs in removing human enteric viruses from wastewaters, particularly as compared to conventional wastewater treatment before and after disinfection.

A total of 73 regular and 28 quality-control (QC) samples were collected at three MBR and two conventional wastewater plants in Ohio during 23 regular and 3 QC sampling trips in 2008-10. Samples were collected at various stages in the treatment processes and analyzed for bacterial indicators E. coli, fecal coliforms, and enterococci by membrane filtration; somatic and F-specific coliphage by the single agar layer (SAL) method; adenovirus, enterovirus, norovirus GI and GII, rotavirus, and hepatitis A virus by molecular methods; and viruses by cell culture. While addressing the main objective of the study - comparing removal of viruses and bacterial indicators in MBR and conventional plants - it was realized that work was needed to identify data analysis and quantification methods for interpreting enteric virus and QC data. Therefore, methods for quantifying viruses, qualifying results, and applying QC data to interpretations are described in this report.

${ }^{1}$ U.S. Geological Survey, Ohio Water Science Center, Columbus, Ohio.

${ }^{2}$ U.S. Department of Agriculture/U.S. Geological Survey Laboratory, Marshfield, Wisconsin.

${ }^{3}$ U.S. Department of Agriculture, Agricultural Research Service, Marshfield, Wis.

${ }^{4} \mathrm{CT}$ Consultants, Mentor, Ohio.

${ }^{5}$ (Formerly) City of Delphos, Ohio.

${ }^{6} \mathrm{CT}$ Consultants, Akron, Ohio.
During each regular sampling trip, samples were collected (1) before conventional or MBR treatment (post-preliminary), (2) after secondary or MBR treatment (post-secondary or post-MBR), (3) after tertiary treatment (one conventional plant only), and (4) after disinfection (post-disinfection). Glass-wool fiber filtration was used to concentrate enteric viruses from large volumes, and small volume grab samples were collected for direct-plating analyses for bacterial indicators and coliphage. After filtration, the viruses were eluted from the filter and further concentrated. The final concentrated sample volume (FCSV) was used for enteric virus analysis by use of two methods - cell culture and a molecular method, polymerase chain reaction (PCR). Quantitative PCR (qPCR) for DNA viruses and quantitative reverse-transcriptase PCR (qRT-PCR) for RNA viruses were used in this study.

To support data interpretations, the assay limit of detection $\left(\mathrm{A}_{\mathrm{LOD}}\right)$ was set for each virus assay and used to determine sample reporting limits (SRLs). For qPCR and qRT-PCR the $A_{L O D}$ was an estimated value because it was not established according to established method detection limit procedures. The SRLs were different for each sample because effective sample volumes (the volume of the original sample that was actually used in each analysis) were different for each sample. Effective sample volumes were much less than the original sample volumes because of reductions from processing steps and (or) from when dilutions were made to minimize the effects from PCR-inhibiting substances. Codes were used to further qualify the virus data and indicate the level of uncertainty associated with each measurement.

Quality-control samples were used to support data interpretations. Field and laboratory blanks for bacteria, coliphage, and enteric viruses were all below detection, indicating that it was unlikely that samples were contaminated from equipment or processing procedures. The absolute value log differences (AVLDs) between concurrent replicate pairs were calculated to identify the variability associated with each measurement. For bacterial indicators and coliphage, the AVLD results indicated that concentrations $<10$ colony-forming units or plaque-forming units per $100 \mathrm{~mL}$ can differ between replicates by as much as $1 \mathrm{log}$, whereas higher concentrations can differ by as much as $0.3 \log$. The AVLD results for viruses 
indicated that differences between replicates can be as great as $1.2 \log$ genomic copies per liter, regardless of the concentration of virus. Relatively large differences in molecular results for viruses between replicate pairs were likely due to lack of precision for samples with small effective volumes.

Concentrations of E. coli, fecal coliforms, enterococci, and somatic and F-specific coliphage in post-secondary and post-tertiary samples in conventional plants were higher than those in post-MBR samples. In post-MBR and post-secondary samples, concentrations of somatic coliphage were higher than F-specific coliphage. In post-disinfection samples from two MBR plants (the third MBR plant had operational issues) and the ultraviolet conventional plant, concentrations for all bacterial indicators and coliphage were near or below detection; from the chlorine conventional plant, concentrations in postdisinfection samples were in the single or double digits. All of the plants met the National Pollutant Discharge Elimination System required effluent limits established for fecal coliforms.

Norovirus GII and hepatitis A virus were not detected in any samples, and rotavirus was detected in one sample but could not be quantified. Adenovirus was found in 100 percent, enterovirus in over one-half, and norovirus GI in about onehalf of post-preliminary wastewater samples. Adenovirus and enterovirus were detected throughout the treatment processes, and norovirus GI was detected less often than the other two enteric viruses. Culturable viruses were detected in post-preliminary samples and in only two post-treatment samples from the plant with operational issues.

\section{Introduction}

Bacterial indicators, such as Escherichia coli (E. coli) and fecal coliforms, are the required microbial measures of effluents for wastewater-discharge permits in Ohio and elsewhere in the United States. Most bacterial indicators do not cause disease but are used to indicate the possible presence of pathogens transmitted via the fecal-oral route. Sampling for viruses and other pathogens in wastewaters is seldom done and is not required. Bacteria, viruses, and protozoa are three types of microorganisms that can be found in wastewater. Waterborne bacterial pathogens in the United States include species of Salmonella, Shigella, Vibrio, Campylobacter, and pathogen strains of $E$. coli. Waterborne protozoan pathogens include Cryptosporidium and Giardia. Human enteric viruses, which cause a wide range of diseases and symptoms and are excreted in high numbers in the feces of infected individuals, include enteroviruses, adenoviruses, noroviruses, rotaviruses, and hepatitis A virus. Many wastewater-treatment processes can remove microorganisms, but no process removes all microorganisms from wastewater.

Membrane bioreactors (MBRs) are a relatively new wastewater-treatment technology in which conventional secondary treatment or secondary with tertiary treatment are replaced by a membrane separation process. The use of this technology is increasing in the United States; for example, in
Ohio, there are 15 operational municipal MBR wastewatertreatment plants and 5 operational industrial MBR facilities. This process is accomplished by submerging membranes in the conventional activated sludge tank to physically separate the solids from the liquid and filter the wastewater through the membrane. The microfiltration membranes used in Ohio and elsewhere have an effective pore size of 0.10 to $0.4 \mu \mathrm{m}$, small enough to reduce concentrations of protozoa ( 4 to $15 \mu \mathrm{m}$ ) and bacteria $(0.5$ to $3 \mu \mathrm{m})$ but too large to theoretically provide reliable reductions of viruses $(0.02$ to $0.08 \mu \mathrm{m})$. There is little information, however, on the effectiveness of MBRs in removing human enteric viruses from wastewaters, particularly as compared to conventional secondary or secondary with tertiary wastewater treatment before and after disinfection. There is also little information comparing virus removal to bacteria and virus indicator (coliphage) removal in these plants.

Methods for quantifying bacterial indicators and coliphage in water and wastewater and interpreting results are well established; however, corresponding methods are not well established for enteric viruses. In order to quantify enteric virus removal in wastewaters, compare virus removal to bacteria and virus indicator removal, and determine the need for disinfection in MBR plants as compared to conventional plants, virus quantification and data interpretation methods are needed. Methods for quantifying viruses in water and wastewater include cell culture and molecular methods. Cell culture methods have been used for years, and data interpretation methods are standardized; however, molecular methods, particularly quantitative molecular methods, are relatively new and require data interpretation procedures that are not well documented. Few studies describe how to interpret enteric virus concentration and quality-control data for solving problems, answering practical questions, and informing the public.

To fill this gap and provide practical information on how to interpret enteric virus data, the U.S. Geological Survey (USGS) and CT Consultants, in cooperation with Ohio Water Development Authority, the City of Delphos, and the U.S. Department of Agriculture/USGS Marshfield (Wiscon$\sin$ ) Laboratory, studied the removal of viruses and indicators throughout the wastewater-treatment process in conventional and MBR plants. The wastewater plants were located in northern Ohio, where disinfection of effluents is required during the recreational season from May through October. During 26 sampling trips over the recreational seasons of 2008-10, 73 regular and 28 quality-control (QC) samples were collected at three MBR and two conventional Ohio wastewatertreatment plants at various stages in the treatment processes. Samples were analyzed for enteric viruses, bacterial indicators, and coliphage.

The goal of the study was to determine whether disinfection is needed after MBR treatment to provide the same level of protection of public health as that found for conventional systems that use disinfection after secondary treatment. While working towards this goal, the study team realized that work was needed to identify data analysis methods for interpreting enteric virus and quality-control data. 


\section{Purpose and Scope}

The purpose of this report is to document procedures for quantifying and qualifying data on concentrations of enteric viruses by use of molecular methods and for applying qualitycontrol sample results. These data-analysis procedures can be used by others who are struggling to interpret and use microbiological data to answer water-resource questions. Data from samples for enteric viruses, bacterial indicators, and coliphage are presented in this report. Quality-control data associated with bacterial indicator, coliphage, and enteric virus data also are discussed to aid in data interpretations.

Current plans (August 2011) are to address the main study goal in companion reports that (1) present concentrations and log removals of bacterial indicators, coliphage, and enteric viruses through wastewater-treatment processes and (2) discuss treatment effectiveness in terms of National Pollutant Discharge Elimination System (NPDES) permit requirements.

\section{Enteric Viruses and Microbiological Indicators of Fecal Contamination}

Enteric viruses include waterborne human pathogenic viruses transmitted through the fecal-oral route. Five groups of enteric viruses were targeted during the study - enteroviruses, adenoviruses, noroviruses, rotaviruses, and hepatitis A virus. Human enteroviruses are among the most commonly detected enteric viruses in contaminated waters (Gregory and others, 2006). More than 60 types of enteroviruses cause a variety of illnesses from mild respiratory infections to serious conditions such as myocarditis. In a study in Milwaukee, enteroviruses in clinical cases and in water samples were found to occur more frequently from July through October than other times of the year (Sedmak and others, 2005). Adenoviruses, the only DNA enteric viruses included in the present study (all other human enteric viruses in this study were RNA viruses), can survive for prolonged periods in environmental waters (He and Jiang, 2005). Although many infections caused by adenoviruses are asymptomatic, adenoviruses have been recognized as important etiological agents of respiratory and gastrointestinal illnesses. Adenoviruses have been proposed as indicators of fecal viral contamination because of their consistent prevalence and stability in human sewage (Bofill-Mas and others, 2006). Noroviruses are one of the most common etiological agents of gastrointestinal illness outbreaks and are highly contagious; as few as 10 viral particles may be sufficient to infect an individual (Centers for Disease Control and Prevention, 2010). Although norovirus infections occur throughout the year, they are expected to be highest during the winter months (da Silva and others, 2007). Rotavirus is the leading cause of severe diarrhea in infants and children worldwide (Centers for Disease Control and Prevention, 2010). Hepatitis A virus causes inflammation of the liver; this disease is self-limiting, and rates in the United States are the lowest they have been in 40 years (Centers for Disease Control and Prevention, 2011).

Cell culture and a molecular method, polymerase chain reaction (PCR), were used in the present study to quantify viruses in wastewater. The cell culture method provides information on the infectivity of the viruses but requires weeks for confirmatory results and does not by itself identify specific viruses. For the cell culture method, a flask containing a layer of mammalian cells is inoculated with sample and examined microscopically for the appearance of cytopathic effects (CPE, cell disintegration or changes in cell morphology). Not all enteric viruses grow in cell culture or exhibit CPE, and no single cell-culture system can be used for all human enteric viruses. Polymerase chain reaction for DNA viruses or reverse-transcriptase PCR (RT-PCR) for RNA viruses has been used to detect specific viruses in different water matrices (Ando and others, 1995; da Silva and others, 2007; De Leon and others, 1990; He and Jiang, 2005; Kuo and others, 2010; Rajal and others, 2007). For both methods, specific polymerase enzymes are used to amplify, to detectable levels, viral nucleic acid sequences that are present in low concentrations in water. The PCR method provides results within a day and can identify specific viruses, but it does not determine the infectivity of the viruses (the viruses do not have to be intact or active to be detected). Although traditional PCR is a presence/absence method, quantitative PCR (qPCR) and quantitative RT-PCR (qRT-PCR) are newer techniques that can provide data on the level of specific viruses in a water sample within 3 hours. The qPCR and qRT-PCR rely on the detection of a fluorescent signal produced during the amplification reaction, and the pattern of signal generation can be used to infer the amount of starting material (DNA or RNA) in the sample.

Many hurdles remain for the accurate quantification of viruses from water matrices by use of qPCR and qRT-PCR (Gregory and others, 2006). Because viruses are generally found in low numbers in treated wastewater, large volumes of sample must first be filtered and concentrated. Recovery by filtration is variable and should be evaluated for each water matrix and virus type (Lambertini and others, 2008). Another obstacle to accurate quantification is the presence of substances that inhibit the PCR, which may be purified along with the viruses. Inhibitory compounds include polysaccharides, divalent cations, and humic, fulvic, or tannic acids present in natural waters. In addition, quantification procedures rely on establishing a robust and reproducible standard curve for each assay and identifying sample-specific detection limits for quantification, none of which are established or standardized.

Quantitative PCR and qRT-PCR assays have been used to determine concentrations of human enteric viruses in water and wastewater. Studies include those that describe concentrations of adenovirus (He and Jiang, 2005; Biofill-Mas and others, 2006; Haramoto and others, 2007; Kuo and others, 2010) and less frequently, concentrations of norovirus (da Silva and others, 2007) or enterovirus (Rutjes, 2005) in different types of water and wastewater samples. Rajal and others (2007) 
describe the quantification of enteroviruses and adenoviruses in storm-water samples. Uncommon in the literature, the equations that were used to determine final virus quantification numbers and sample-specific limits of detection were clearly defined in Rajal and others (2007).

Methods for bacterial indicators and coliphage were used in the present study because they are used to satisfy permitting requirements or are the basis for water-quality standards for recreational or drinking waters. Unlike virus quantification methods, methods to detect fecal-indicator bacteria (fecal coliforms, E. coli, and enterococci) in water and wastewater are well established and yield highly reproducible results (American Public Health Association (APHA) and others, 2005). However, concentrations of fecal-indicator bacteria do not necessarily correlate with the presence or concentration of enteric viruses in environmental samples. Researchers sometimes use coliphages as surrogates for the transport and survival of enteric viruses in the environment. Coliphages are viruses that infect and replicate in coliform bacteria, such as $E$. coli, and do not infect or harm humans. They are similar to enteric viruses in size and shape, transport characteristics, and resistance to disinfection processes. The two main groups of coliphages used in water-quality studies are somatic and F-specific coliphages, and they are both present in appreciable numbers in sewage (Sobsey and others, 1995). Somatic coliphages infect coliform bacteria by attachment to the outer cell membrane or cell wall; they are widely distributed in both fecal-contaminated and uncontaminated waters and may not be consistent indicators of fecal contamination (Sobsey and others, 1995). F-specific coliphages infect coliform bacteria only by attachment to the F-pilus, a structure made only by bacteria grown at higher temperatures. F-specific coliphage found in environmental samples, therefore, presumably come from warmblooded animals or sewage and are generally present at low levels in uncontaminated environmental samples (Long and Sobsey, 2004). A method to enumerate coliphage in water is established and documented (U.S. Environmental Protection Agency, 2001a).

\section{Methods of Study}

The five small- to medium-sized wastewater-treatment plants included in this study were three Kubota ${ }^{\circledR}$ Membrane Systems by Ovivo MBR Process system plants with ultraviolet (UV) disinfection, one conventional treatment plant with UV disinfection and tertiary treatment, and one conventional plant with chlorine disinfection (table 1). Plants 1-3 were included in the original study design, and plants 4 and 5 were added when additional funding was secured; sampling at plant 2 was discontinued in 2010 because of operational issues and an effluent contamination that was identified and eliminated after sampling. The MBR plants selected for this study all used the same manufacturer and design, with a pore size of $0.4 \mu \mathrm{m}$. In this report, a conventional plant refers to an activated sludge biological process consisting of aeration tanks and secondary tanks or clarifiers (fig. 1). Air is introduced to the wastewater in the aeration tank whereby the organics are reduced to cell matter (solids) and stabilized before removing the solids by gravity in the secondary settling tanks. In some conventional plants a tertiary treatment process is used. Tertiary treatment removes more solids than secondary treatment does, and it typically targets the removal of suspended solids and nutrients such as phosphorus and nitrogen. A common tertiary method is filtration, whereby sand or activated carbon is used to filter the wastewater. In this study, plant 3 provides tertiary treatment through sand filtration.

Table 1. Membrane bioreactor (MBR) and conventional wastewater-treatment plants, 2008-10.

[Mgal/d, million gallons per day; QC, quality-control samples]

\begin{tabular}{|c|c|c|c|c|c|}
\hline $\begin{array}{l}\text { Plant } \\
\text { number }\end{array}$ & Treatment system & Year built & $\begin{array}{l}\text { Design } \\
\text { capacity } \\
\text { (Mgal/d) }\end{array}$ & $\begin{array}{l}\text { Average } \\
\text { daily flow } \\
\text { (Mgal/d) }\end{array}$ & $\begin{array}{l}\text { Sample numbers } \\
\text { (in parentheses) } \\
\text { and dates }\end{array}$ \\
\hline 1 & $\begin{array}{l}\text { MBR with ultraviolet } \\
\text { disinfection }\end{array}$ & 2006 & 12 & 3.8 & $\begin{array}{l}\text { 2008-(1) Aug. 12, (5) Oct. } 21 \\
\text { 2009-(6) May 12, (8) June 16, } \\
\text { (11) Aug. 4, (13) Oct. } 14 \\
\text { 2010-May } 5 \text { (QC only) }\end{array}$ \\
\hline 3 & $\begin{array}{l}\text { Conventional tertiary (sand } \\
\text { filtration) with ultraviolet } \\
\text { disinfection }\end{array}$ & $\begin{array}{c}\text { 1985; upgraded late } \\
\text { 1990s }\end{array}$ & 1.6 & .5 & $\begin{array}{l}\text { 2008-(3) Sept. } 22 \\
\text { 2009-(9) June 29, (12) Sept. } 14 \\
\text { 2010-(18) Aug. } 2\end{array}$ \\
\hline 4 & $\begin{array}{l}\text { MBR with ultraviolet } \\
\text { disinfection }\end{array}$ & 2008 & 6 & 3 & $\begin{array}{l}\text { 2010-April } 13 \text { (QC only), (15) June 23, } \\
\text { (17) July 21, (19) Aug. 17, (21) Sept. 14, } \\
\text { (23) Oct. } 5\end{array}$ \\
\hline
\end{tabular}




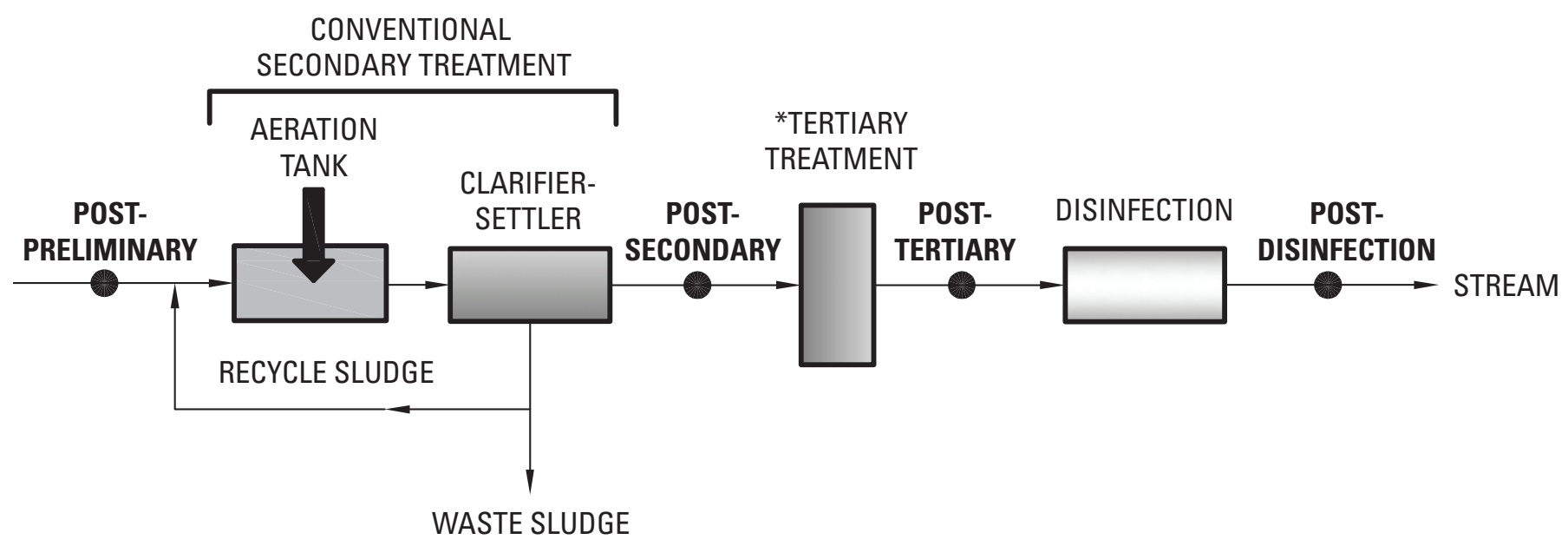

*Plant No. 5 does not employ Tertiary treatment

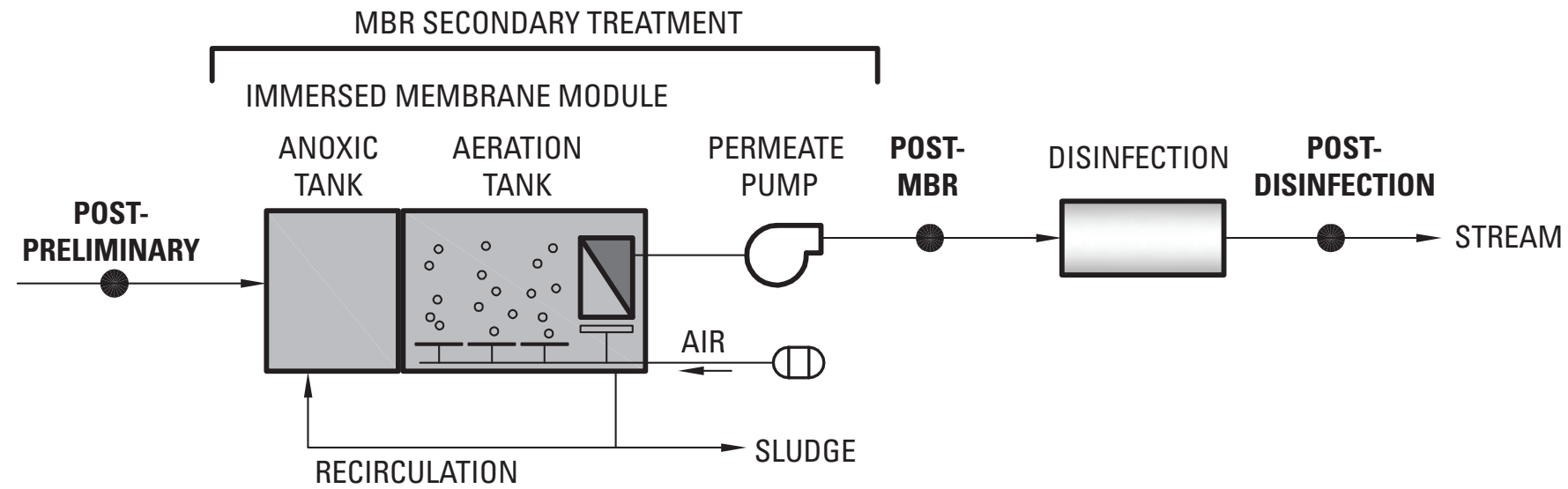

\section{EXPLANATION}

- Indicates sampling points

[Modified from www.newworldencyclopedia.com and wastewaterengineering.com]

Figure 1. Processes involved in wastewater treatment for conventional and Membrane bioreactors (MBR) facilities, and sampling points for the 2008-10 study. 


\section{Sampling Frequency and Procedures}

Twenty-three regular sampling trips and three qualitycontrol trips were made during the recreational seasons (May 1-October 31) of 2008-10 (table 1). During each regular sampling trip, one wastewater plant was visited, and 3 to 4 samples were collected at different points within the treatment stream (fig. 1):

- Before conventional or MBR secondary treatment (post-preliminary)

- After secondary or MBR treatment (post-secondary or post-MBR)

- After tertiary, but before disinfection (post-tertiary) Plant 3 only

- After disinfection (post-disinfection)

Compensation was made for detention time between sample points within the treatment plant to ensure the approximate same slug of water was collected. Both filtered samples and fixed-interval grab samples were collected, as described below.

Glass-wool fiber filtration (Lambertini and others, 2008) was done to concentrate enteric viruses from large-volume samples. Filters were prepared by order (USDA/USGS Laboratory, Marshfield, Wis.) and stored in the refrigerator for up to a month before use. Glass-wool filtration was also used in the early part of the study to compare concentrations of coliphage after filtration to those obtained by direct plating of a grab sample. Filtration was done in the field, with the exception of the post-preliminary wastewater samples, which were filtered at the USGS Ohio Water Microbiology Laboratory (OWML) in Columbus, Ohio. Sample volumes for enteric viruses were established on the basis of initial experiments in the OWML (unpublished data). The following sample volumes were filtered for enteric viruses and coliphage:

- Post-preliminary-4 L

- Post-secondary-100 L or 3.5 hours filtration, whichever came first

- Post-MBR, post-tertiary, and post-disinfection-500 L or 3.5 hours filtration, whichever came first

For field filtration, the sampling apparatus consisted of an inlet tubing line, a Masterflex ${ }^{\circledR}$ peristaltic pump (Cole Parmer, Vernon Hills, Ill.), glass-wool filter, and a discharge tubing line (fig. 2). The peristaltic pump was adjusted to achieve a flow rate of $2-3 \mathrm{~L} / \mathrm{min}$. If needed, a second peristaltic pump was used to meter $0.5 \mathrm{~N}$ hydrochloric acid $(\mathrm{HCl})$ through smalldiameter plastic tubing into the inlet line $(1 \mathrm{~N} \mathrm{HCl}$ was used the first year of the study) to adjust the sample $\mathrm{pH}$ to 6.5-7.0, in accordance with the glass-wool filter protocol (Lambertini and others, 2008). Before filtering the wastewater through the filter, the sample line was rinsed with wastewater and the $\mathrm{pH}$ was measured from the discharge tubing by using a $\mathrm{pH}$ probe in a glass beaker, in accordance with standard USGS protocols (Wilde, 2005). If the $\mathrm{pH}$ was greater than 7.0, the $\mathrm{HCl}$ metering pump was started. Over the next few minutes, the flow rate of $\mathrm{HCl}$ was adjusted to achieve the target $\mathrm{pH}$. After the target $\mathrm{pH}$ was established, the glass-wool filter was connected to the line from the peristaltic pump. The $\mathrm{pH}$ was measured again and additional adjustments to the flow rate of $\mathrm{HCl}$ were made as needed. The $\mathrm{pH}$ and flow rate were measured subsequently at least every 30 minutes for all samples, even if the acid metering pump was not used. Flow rate was measured manually for 1 minute by collecting discharge wastewater into a graduated cylinder or marked carboy. Disposal of the discharged post-disinfection wastewater was via the effluent of the treatment system. All other wastewater was discharged into a drain or other point that flowed back through the treatment system. After the required volume was collected or the required time frame was achieved, the pumps were turned off, the filter was disconnected and placed in a plastic bag, and the inlet and outlet lines were sealed. Original sample volume was calculated from the flow rate and sampling duration.

Grab samples were collected for analyses of bacterial indicators and coliphage and for lab filtration of post-preliminary wastewater samples. This was done by collecting slightly less than $1 \mathrm{~L}$ every 10 minutes for 1 hour $(5-6 \mathrm{~L}$ of postpreliminary sample for filtration) or $0.5 \mathrm{~L}$ every 10 minutes for 1 hour ( $3 \mathrm{~L}$ for bacterial indicators and coliphage). Subsamples were collected by use of 1-L sterile polypropylene bottles and composited into sterile 3 -L bottles. Bacterial indicators and most coliphage analyses were done by direct plating of grab samples.

Filters and grab samples were kept on ice before processing. Samples not processed onsite and filters were transported to the OWML by vehicle for processing or analyses within 24 hours of collection. In the OWML, specific conductance and turbidity were measured by use of a specific conductance meter and a turbidimeter, respectively. For post-preliminary samples, wastewater was filtered in the laboratory under a biosafety cabinet by using the same procedure described above for field samples. One difference in the protocol was that the $\mathrm{pH}$ adjustment for post-preliminary wastewater samples was done before glass-wool filtration by slowly adding $1 \mathrm{~N} \mathrm{HCl}$ to the sample while stirring until the $\mathrm{pH}$ was between 6.5 and 7.0.

Cleaning and decontamination for non-autoclavable tubing, connectors, bottles, and other equipment for sampling included a 15-minute soak in dilute detergent, a rinse with tapwater, sterilization in 0.1 percent sodium hypochlorite for 30 minutes, dechlorination with 0.05 percent sterile sodium thiosulfate for 5 minutes, and a rinse with sterile deionized water. Autoclavable equipment was cleaned with detergent, rinsed with tapwater and deionized water, and autoclaved for 15 minutes. 


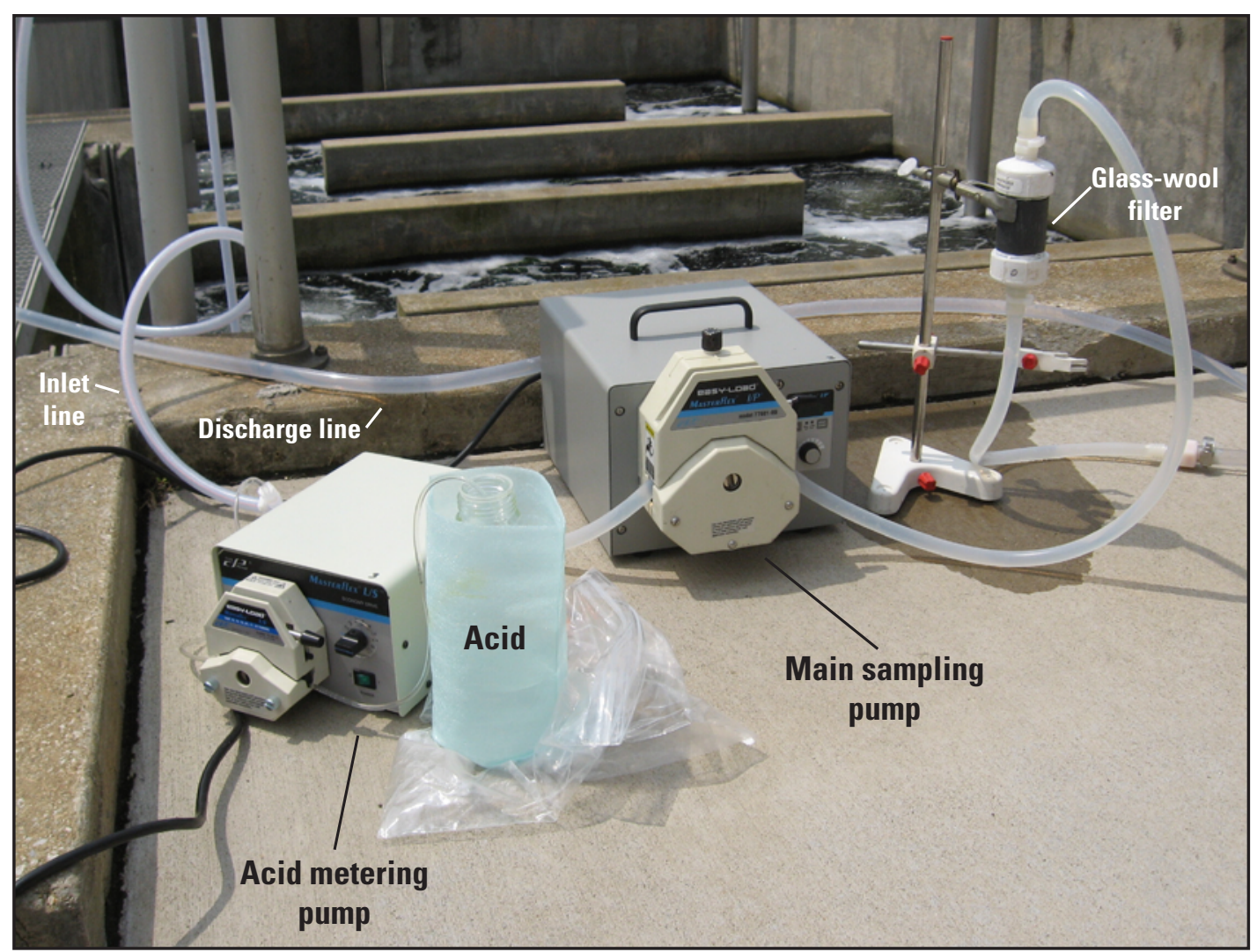

Figure 2. Equipment setup for filtering wastewater samples for enteric viruses.

\section{Microbiological Analyses}

Wastewater samples were analyzed for culturable enteric viruses; for enterovirus, norovirus GI and GII, rotavirus, and hepatitis A virus by qRT-PCR and for adenovirus by qPCR; for $E$. coli, fecal coliforms, and enterococci by membrane filtration; and for somatic and F-specific coliphage by the U.S. Environmental Protection Agency (USEPA) single agar layer method and by a commercially available alternative method, EasyPhage (Scientific Methods Inc., Granger, Ind.). Processing and analyses of samples for bacterial indicators were done in the field vehicle or at the OWML within 6 hours of sample collection. Analyses of samples for coliphage and processing of filters for enteric viruses were done at the OWML within 24 hours of sample collection.

\section{Initial Processing of Samples}

After filtration, the viruses were eluted from the filter by use of a beef extract and glycine elution solution, in accordance with a procedure described in Lambertini and others (2008). A portion of the eluate was removed for coliphage analysis, and the remainder was concentrated for enteric virus analysis. Briefly, the eluate (approximately $200 \mathrm{~mL}$ ) was adjusted to $\mathrm{pH} 7-7.5$ with $1 \mathrm{M} \mathrm{HCL}$ and flocculated with 16.0 g polyethylene glycol (PEG) and 2.3 g sodium chloride. The mixture was stirred for 1 hour at $4^{\circ} \mathrm{C}$, held overnight at $4^{\circ} \mathrm{C}$, and then centrifuged at $3,300 \times g$ for 1.5 hours. The pellet was resuspended in $0.15 \mathrm{M}$ sodium phosphate to bring the final concentrated sample volume (FCSV) up to $10 \mathrm{~mL}$ for post-preliminary samples or $5 \mathrm{~mL}$ (2008) or $6 \mathrm{~mL}$ (2009-10) for other wastewater-sample types. The FCSV was aliquoted into several centrifuge tubes: two to four tubes for storage in the freezer and one tube with 4-6 mL, depending on the sample type, for transport to the USDA/USGS Laboratory in Marshfield, Wis. ("Marshfield Laboratory"), for enteric virus analysis. The FCSVs were transported to the Marshfield Laboratory in batches on dry ice by overnight delivery.

\section{Enteric Viruses by Cell Culture}

The cell culture method was done at the Marshfield Laboratory, based on procedures described in U.S. Environmental Protection Agency (2001b). The cell culture method is a twostep procedure that consists of (1) screening and (2) quantification by most probable number (MPN). To screen for different types of culturable enteric viruses, $0.33 \mathrm{~mL}$ of FCSV was inoculated into each of three culture flasks containing one of three cell lines: buffalo green monkey kidney cells (BGMK), rhabdomyosarcoma (RD) cells, and Human Caucasian colon adenocarcinoma (Caco-2) cells. The three cell lines were used because different human enteric viruses grow preferentially on different cell lines (Knipe and others, 2007). The cultures were observed for up to 14 days for cytopathic effects (CPE) to evaluate on which cell line the viruses were most prolific. A portion of the cell lysate was analyzed by qRT-PCR for enterovirus to confirm that an enterovirus was the cause of the CPE. 
If a positive result was obtained through screening, then culturable enteric viruses were quantified by MPN by using the selected cell line. Thirty wells were inoculated with $0.04 \mathrm{~mL}$ of FCSV: 10 with undiluted FCSV, 10 with FCSV diluted 1:5 with sterile $0.15 \mathrm{M}$ sodium phosphate, and 10 with FCSV diluted 1:25, for a total inoculum in the 30 wells of $0.496 \mathrm{~mL}$. Wells were incubated for 14 days and periodically examined for CPE. After 14 days of observation, the cells were lysed and the supernatant passed into new wells with cells to confirm the first passage results. If the initial dilutions failed to produce the appropriate mix of virus positive and virus negative wells for calculating the MPN, a new set of 30 wells was inoculated with different FCSV dilutions and the incubation process was repeated for another 28 days. MPNs were calculated on the basis of CPE. To confirm that the CPE was caused by an enterovirus, the cell lysate from one positive well was analyzed for enteroviruses by qRT-PCR.

\section{DNA Extraction and Enteric Viruses by qPCR or qRT-PCR}

At the Marshfield Laboratory, viral nucleic acids were extracted from the FCSV with a QIAamp ${ }^{\circledR}$ DNA Blood Mini Extraction Kit (Qiagen, Valencia, Calif., 51104) and AVL Buffer (Qiagen, 19073) to yield a suspension of $50 \mu \mathrm{L}$ in 2008 and $65 \mu \mathrm{L}$ in 2009-10. AVL Buffer is a lysis buffer designed for viruses. The qPCR/qRT-PCR assays are described in Lambertini and others (2008), and the primers and probes for enterovirus, adenovirus, norovirus, rotavirus, and hepatitis A virus are listed in table 2. Assays for adenovirus groups C, D, and $\mathrm{F}$ were performed on all samples (Cromeans and others, 2005). In addition, assays for adenovirus A and B were performed on samples collected in 2009-10 (Susan K. Spencer, USDA/USGS Marshfield Laboratory, oral commun., 2009). Quantitative PCR was performed on a LightCycler $(480$ System (Roche Diagnostics Corporation, Indianapolis, Ind.) with LightCycler 480 Software Version 1.5.0. Hepatitis G virus (HGV) armored RNA (Asuragen, Inc., Austin, Tex.) was used as a control to measure PCR inhibition; sample extracts were diluted if $\mathrm{HGV}$ results indicated that inhibition occurred.

\section{Standard Curves for Enteric Viruses by qPCR or qRT-PCR}

At the Marshfield Laboratory, standard curves were prepared as described in Lambertini and others (2008). Briefly, virus stocks were treated with Benzonase ${ }^{\circledR}$ (Novagen, Madison, Wis.) for 30 minutes at $37^{\circ} \mathrm{C}$, followed by incubation for 2 days at $4^{\circ} \mathrm{C}$. Benzonase is a genetically engineered endonuclease that attacks and degrades all noncapsulated forms of DNA and RNA. Stocks were then extracted, the amount of virus RNA or DNA was measured by using RiboGreen ${ }^{\circledR}$ or PicoGreen ${ }^{\circledR}$ (Molecular Probes, Eugene, Or.), and the number of genomic copies (gc) was calculated. RiboGreen and PicoGreen are dyes that fluoresce when bound to RNA or DNA, respectively, and the intensity of fluorescence in a sample is proportional to the concentration of RNA or DNA. After quantification, viral stocks were serially diluted and seeded into a negative FCSV made by filtering a negative tapwater sample, eluting with beef extract, and precipitating with PEG. Each standard point was extracted in duplicate and then tested by qPCR or qRT-PCR in triplicate once a quarter. With every qPCR or qRT-PCR run, a reference control (low copy standard from the standard curve) was run and compared to the results of the quarterly standard curve. The reference control was required to be $\pm 1 / 2$ the crossing threshold $(\mathrm{Ct})$ value $^{1}$ from the standard curve line for acceptance (Lambertini and others, 2008). If the reference control was greater than $\pm 1 / 2 \mathrm{Ct}$, then a new standard curve was created and the samples were reanalyzed.

\section{Assay Limits of Quantification and Sample Reporting Limits for Enteric Viruses by qPCR, qRT-PCR, and Cell Culture}

In water-resource studies, such as the MBR wastewater study described in this report, limits of detection or quantification help support a robust data analysis and the ability to effectively interpret results. By calculating the limits of detection or quantification, results can be reported as less than an established value per volume instead of reporting nondetections as zero. For example, reporting one result as $<1 \mathrm{gc} / \mathrm{L}$ would be quite different than reporting a second result as $<500 \mathrm{gc} / \mathrm{L}$. Further, limits of detection or quantification are needed to qualify the data and thus more accurately report with confidence or lack of confidence when viruses are determined to be absent or present in low numbers.

For qPCR and qRT-PCR, the assay limit of quantification $\left(\mathrm{A}_{\mathrm{LOQ}}\right)$ is defined by Rajal and others $(2007)$ as the lowest concentration of virus genomes that remain within the linear range of quantification. In Rajal and others (2007), the $\mathrm{A}_{\mathrm{LOQ}}$ was determined by preparing tenfold dilutions of the target DNA or RNA in deionized water and quantifying by qPCR or qRT-PCR, respectively — an approach applicable to TaqMan systems. The Roche system used in the present study is based on second-derivative $\mathrm{Ct}$ determination and nonlinear-fit algorithms for standard curve development. For the data in this report, therefore, the $\mathrm{A}_{\mathrm{LOQ}}$ was determined by constructing a linear approximation of six dilutions used to develop the standard curve and extrapolating to $1 \mathrm{gc}$. For cell culture, the $\mathrm{A}_{\mathrm{LOQ}}$ is the lowest concentration of viruses that can be quantified by observing CPE. For screening, the $\mathrm{A}_{\mathrm{LOQ}}$ is 1 virus or CPE. For cell-culture MPN analysis, the $\mathrm{A}_{\mathrm{LOQ}}$ is $2.18 \mathrm{MPN} / \mathrm{mL}$, as determined by assuming 1 virus in the undiluted sample and zero virus in the 1:5 and 1:25 dilutions (U.S. Environmental Protection Agency, 2001b).

\footnotetext{
${ }^{1}$ The $\mathrm{Ct}$ value is the point at which fluorescence in a sample crosses an established threshold.
} 
Table 2. Primers and probes for enteric viruses.

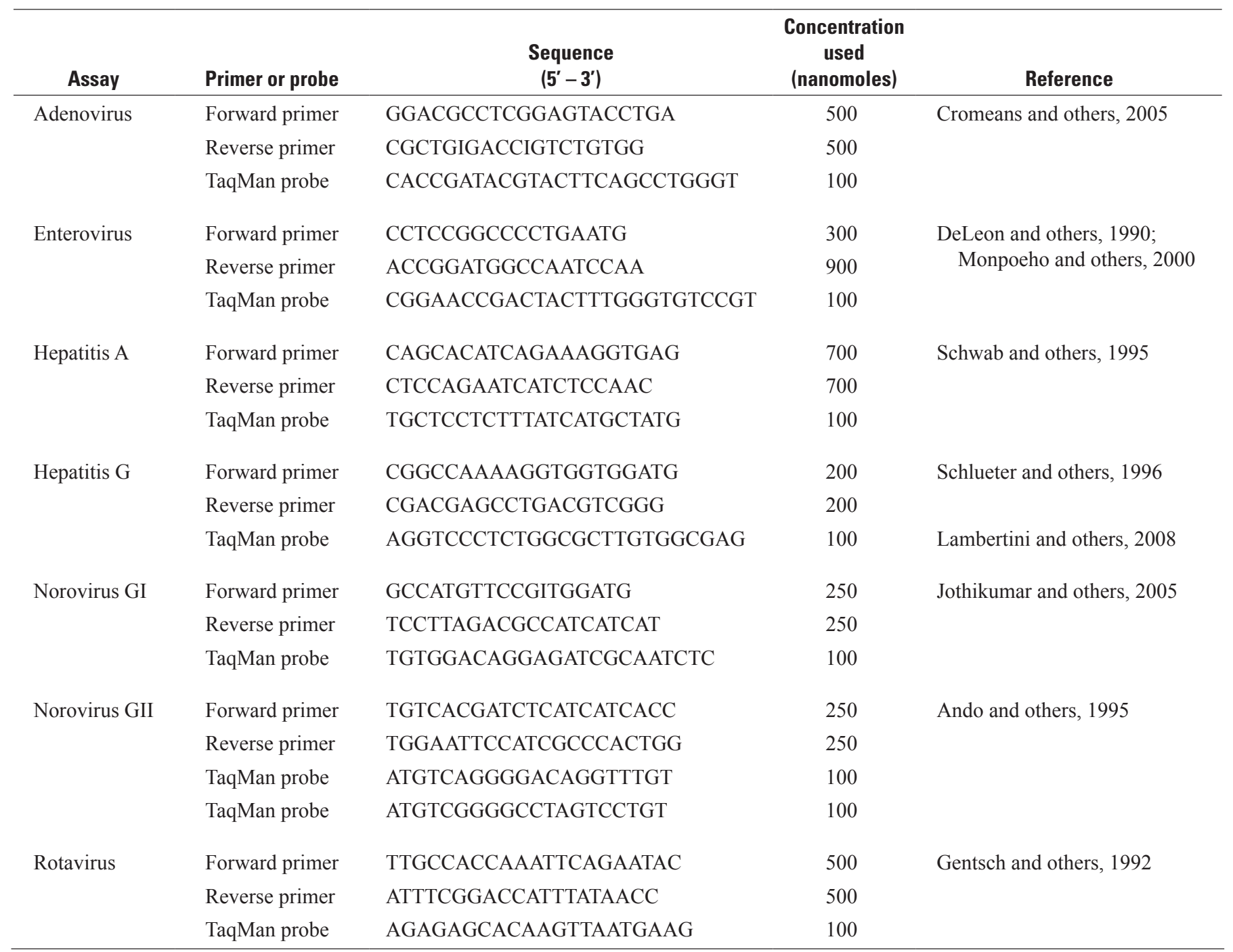

Rajal and others (2007) also determined qPCR or qRTPCR assay limits of detection $\left(\mathrm{A}_{\mathrm{LOD}}\right)$ according to established method detection limit (MDL) procedures commonly used by chemists (U.S. Environmental Protection Agency, 2010). The general approach for determining an MDL is to analyze at least seven replicate samples near the expected MDL in pure water. The MDL is the minimum concentration of a substance that can be measured and reported with 99 percent confidence that the concentration is greater than zero. In the present study, MDLs were not determined; therefore, for qPCR and qRT-PCR results, the $\mathrm{A}_{\mathrm{LOQ}}$ was used as the $\mathrm{A}_{\mathrm{LOD}}$. This $\mathrm{A}_{\mathrm{LOD}}$ was, therefore, an estimated value because it was not identified according to established MDL procedures; the actual sensitivity will need to be established in the future. For cell-culture screening analysis, the $\mathrm{A}_{\mathrm{LOQ}}$ and $\mathrm{A}_{\mathrm{LOD}}$ are both $1 \mathrm{CPE}$ or 1 virus. For cell-culture MPN analysis, the $\mathrm{A}_{\mathrm{LOD}}$ is calculated as $1.08 \mathrm{MPN}(2.18 \mathrm{MPN} / \mathrm{mL} \times 0.496 \mathrm{~mL})$, where $2.18 \mathrm{MPN} / \mathrm{mL}$ is the $\mathrm{A}_{\mathrm{LOQ}}$ and $0.496 \mathrm{~mL}$ is the total inoculum of sample added into 30 wells.
Because original sample volumes and dilutions were different for each sample in the current study, the $\mathrm{A}_{\mathrm{LOD}}$ was applied on a sample-by-sample basis in order to determine sample reporting limits (SRLs). The SRLs are the "less-than values," or the limits of detection for each sample and assay. In calculating the SRL, it is important to first understand that only a small fraction of the original FCSV used for extraction was used for qPCR or qRT-PCR. For example, figure 3 shows that only $33.6 \mu \mathrm{L}(2008)$ or $25.8 \mu \mathrm{L}(2009-10)$ for qPCR and $5.78 \mu \mathrm{L}(2008)$ or $4.45 \mu \mathrm{L}(2009-10)$ for qRT-PCR of the original $280 \mu \mathrm{L}$ of FCSV used for extraction (and concentrated to 50 or $65 \mu \mathrm{L}$ ) was actually used for analysis; this is called the effective FCSV. Effective FCSVs were less for enterovirus and norovirus GI than for adenovirus because the extracted eluate was further reduced through the RT steps. For cell culture screening and MPN analysis, the additional preparation steps and reductions in FCSV volumes shown in figure 3 do not apply; therefore, the effective FCSVs were the amounts directly added to cells $-0.33 \mathrm{~mL}$ for screening and $0.496 \mathrm{~mL}$ for MPN analysis. 


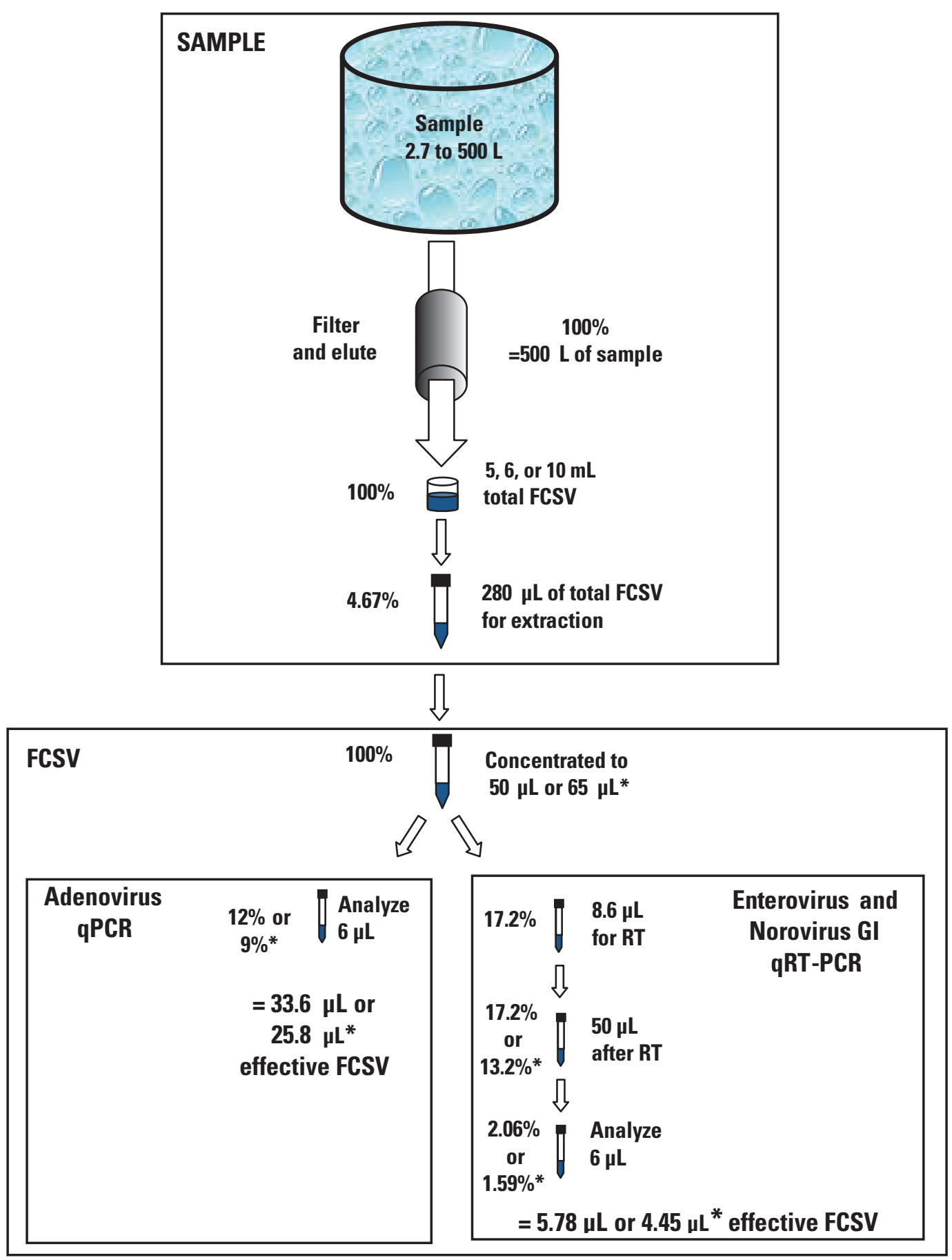

Figure 3. Determination of effective final concentrated sample volumes (FCSVs) for quantitative polymerase chain reaction (qPCR) for adenovirus or quantitative reverse transcriptase PCR (qRT-PCR) for enterovirus or norovirus GI. (L, liter; \%, percent; $\mathrm{mL}$, milliliter; $\mu \mathrm{L}$, microliter; values followed by an asterisk indicate a change in volume of FCSV analyzed between 2008 (first value) and 2009-10 (second value).) 
Effective sample volume is the actual amount of sample that was analyzed. Effective sample volumes were sample specific because (1) original sample volumes were not consistent, (2) total FCSV volumes varied among different types of wastewaters and between years, and (3) samples were sometimes diluted because of PCR inhibition. Taking into account these factors, the following equation was used to calculate the effective sample volume (Ves):

$$
\text { Ves }=\frac{\text { FCSVeffective }}{\text { FCSVtotal }} * \text { Sample } * \frac{1}{\text { dilution factor }}
$$

where

$$
\begin{array}{cl}
\text { FCSVeffective } & \begin{array}{l}
\text { is the volume of FCSV analyzed, } \\
\text { FCSVtotal } \\
\text { is the total volume of FCSV produced from } \\
\text { each sample, }
\end{array} \\
\text { Vsample } & \text { is the original volume of sample filtered, and } \\
\text { dilution factor } & \begin{array}{l}
\text { is the dilution factor used for each sample } \\
\text { extract. }
\end{array}
\end{array}
$$

This same equation was used for qPCR, qRT-PCR, and cell culture except that for cell culture calculations, a dilution factor was not applied.

For qPCR and qRT-PCR, the SRL is based on the effective sample volume and $A_{L O D}(1 \mathrm{gc})$, as follows:

$$
S R L=\frac{1 g c}{V e s}
$$

For cell culture by screening, the SRL is similarly based on the effective sample volume and $\mathrm{A}_{\mathrm{LOD}}$ (1 virus), as follows:

$$
S R L=\frac{1 \text { virus }}{\text { Ves }}
$$

For cell culture by MPN, the SRL is based on the ALOD (1.08 MPN), as follows:

$$
S R L=\frac{1.08 M P N}{V e s}
$$

\section{Indicator Bacteria and Coliphage}

Analyses of samples for the bacterial indicators E. coli, enterococci, and fecal coliforms were done by preparing serial dilutions for plating by standard membrane filtration methods. Appropriate dilutions were based on sample type and ranged from $0.0003 \mathrm{~mL}$ for post-preliminary samples to $250 \mathrm{~mL}$ for post-disinfection samples. For E. coli, the modified mTEC agar method (U.S. Environmental Protection Agency, 2006a) was used. Modified mTEC agar plates were incubated at $35^{\circ} \mathrm{C}$ for 2 hours, followed by incubation at $44.5^{\circ} \mathrm{C}$ for 22 hours; magenta colonies were counted as E. coli. The mEI agar method is a one-step method for the enumeration of enterococci (U.S. Environmental Protection Agency, 2006b). Agar plates were incubated at $41^{\circ} \mathrm{C}$ for 24 hours, and all colonies with a blue halo were recorded as enterococci, regardless of colony color. The $\mathrm{mFC}$ agar method was used for enumeration of fecal coliforms (Britton and Greeson, 1987). Agar plates were incubated at $44.5^{\circ} \mathrm{C}$ for 22 to 24 hours, and blue colonies were counted as fecal coliforms. Results from membrane filtration analyses were recorded as colony forming units per 100 milliliters (CFU/100 mL).

The single agar layer (SAL) procedure was mainly used for enumeration of F-specific and somatic coliphage (U.S. Environmental Protection Agency, 2001a). Antibioticresistant host-culture strains $E$. coli $\mathrm{CN}-13$ (resistant to nalidixic acid) and E. coli F-amp (resistant to streptomycin and ampicillin) were used as hosts for somatic and F-specific coliphage, respectively. A $100-\mathrm{mL}$ water sample, eluate, or a sample or eluate dilution was combined with magnesium chloride, log-phase host bacteria, and double-strength tryptic soy agar. The sample mixture was poured into plates and incubated at $36^{\circ} \mathrm{C}$ for $16-24$ hours. Circular lysis zones (plaques) were counted and summed for all plates from a single sample. The quantity of coliphage in a sample is expressed as plaque forming units per 100 milliliters (PFU/100 mL).

An alternative method, EasyPhage (Scientific Methods Inc., Granger, Ind.), was tested on 10 post-preliminary, postMBR, or post-secondary samples in 2008 for enumeration of F-specific and somatic coliphage. EasyPhage eliminates the need to handle molten agar. For each sample, two bottles of EasyPhage agar were preheated in a $35^{\circ} \mathrm{C}$ incubator for 1 hour, one bottle each for F-specific and somatic coliphage. To each warmed bottle, $100 \mathrm{~mL}$ of sample or sample dilution, $2 \mathrm{~mL}$ of antibiotic, $0.7 \mathrm{~mL}$ of EasyPhage stain, and $3.5 \mathrm{~mL}$ of the bacterial host were added. Twenty milliliters of each mixture was added to each of ten $100 \times 15 \mathrm{~mm}$ Petri plates for a total of 10 plates per sample. After incubation at $36^{\circ} \mathrm{C}$ for $16-24$ hours, the blue plaques were counted as positive for coliphage.

\section{Quality Assurance and Quality Control}

Standard field and data management quality-assurance practices for USGS water-quality activities in Ohio are described in Francy and Shaffer (2008). Standard laboratory quality-assurance/quality-control (QA/QC) practices for the OWML are described in Francy and others (2010).

To facilitate identification of sampling and analytical bias, field personnel collected equipment blanks, field blanks, field concurrent replicates, method test samples, and seeded matrix controls. The types and numbers of QC samples for each group of microorganism are listed in the subsections below. General definitions of QC samples are provided in the glossary. 


\section{Indicator Bacteria and Coliphage}

Laboratory QC samples for bacterial indicators and coliphage, with information on reagent and media preparation and procedures, are described in Francy and others (2010). In addition to the routine QC samples, method test samples for coliphage were analyzed. These consisted of filtration test samples and EasyPhage test samples. Filtration test samples were replicate samples analyzed by both direct plating and eluate plating for coliphage. Filtration test samples were collected to provide data on recoveries of coliphage in wastewater by use of glass-wool filters. EasyPhage test samples were replicate samples analyzed by both the SAL and EasyPhage methods and were done to determine whether the EasyPhage method is a suitable alternative to the standard SAL method.

Field QC samples for bacteria and (or) coliphage consisted of field blanks and concurrent replicates. Field blanks were aliquots of sterile buffered water poured into sample bottles under actual field conditions, transported and analyzed in the same manner as a regular sample. A field concurrent replicate was collected by alternating the collection of a second grab sample with the first one and compositing the second sample into a separate 3-L bottle.

\section{Enteric Viruses}

Laboratory analytical QC samples for enteric viruses by qPCR or qRT-PCR are listed in Lambertini and others (2008). Quality-control samples were processed with each batch of samples and included extraction positive and negative controls, as well as separate PCR positive and negative controls. Each sample was assayed in duplicate by qPCR or qRT-PCR. The laboratory QC samples for enteroviruses by cell culture are described in USEPA (2001b). They consisted of an inoculum of sodium phosphate buffer (PBS pH 7.0-7.5) as the negative control and $20 \mathrm{PFU}$ poliovirus Sabin 3 as the positive control for each batch of samples. Each sample enumerated by cell culture MPN had its own negative control.

Field QC samples for enteric viruses consisted of an equipment blank, field blanks, concurrent replicates, and seeded matrix controls. Blank samples consisted of $10 \mathrm{~L}$ of autoclaved, dechlorinated tapwater treated in the same manner as a regular filtered sample in the OWML (equipment blank) or at a sampling location (field blank). Field concurrent replicates were collected by one of two methods: (1) alternating the collection of a second grab sample with the first one and compositing the second sample in two separate 3 -L bottles (post-preliminary samples) or (2) filtering a second wastewater sample onsite concurrently with a second filtration apparatus.

Seeded matrix controls were collected from representative wastewater matrixes to determine the recovery of viruses through all processing and analytical steps. Samples were seeded with Mahoney enterovirus (U.S. Environmental Protection Agency, Cincinnati, Ohio) to achieve target seed amounts of $10^{4}$ viruses, estimated by the OWML by use of a RiboGreen assay. Four-liter samples of post-preliminary wastewater were seeded in the laboratory and then filtered. For other wastewater samples, all but the last $20 \mathrm{~L}$ were filtered onsite; the $20-\mathrm{L}$ remaining volume was collected, transported to the laboratory, seeded, and filtered with the same filter that was used onsite for that sample. Unseeded controls were analyzed in conjunction with a seeded matrix control to determine background concentrations of enteroviruses.

\section{Indicator Bacteria, Coliphage, and Viruses in Wastewater}

Field personnel collected 73 regular samples (tables 3 and 4 , at back of report) during the recreational seasons of 2008-10. One equipment blank and four field blanks, each analyzed for different groups of microorganisms, were collected (table 5). Other quality-control samples included 10 bacteria and coliphage concurrent replicates (table 6); 25 method test samples, 10 of which were also EasyPhage test samples (table 7); and 13 enteric virus replicates (tables 4 and 8). Specific conductance and initial $\mathrm{pH}$ were measured at the time of sampling and turbidity was measured at the OWML (table 3).

\section{Enumeration Considerations for Enteric Viruses by $q P C R$ and $q R T-P C R$}

In order to achieve the objectives of this study, it was important to quantify viruses as accurately as possible, identify lower detection limits, and qualify any uncertainties associated with a viral measurement. Using available data from the analytical laboratory, standard curves were constructed to estimate the assay limit of quantification $\left(\mathrm{A}_{\mathrm{LOQ}}\right)$. Sample reporting limits (SRLs) were calculated from the effective volume for each sample and the $\mathrm{A}_{\mathrm{LOQ}}$. On the basis of the SRLs, there was a need to further qualify measurements. Codes for qualifying the data are those established by the USGS National Water Information System for QWDATA (U.S. Geological Survey, 2010).

Table 9 lists performance characteristics for each standard curve for each assay. The dynamic range of the standard curve is the lowest and highest concentrations of standards that were used in the standard curve development. The amplification efficiency is calculated using the following equation:

$$
E=10^{(-1 / \text { slope })}-1
$$

The efficiency of the PCR should be $90-110$ percent meaning doubling of the target sequence at each cycle, which corresponds to a slope of -3.1 to -3.6 in the standard curve. Because norovirus GII and hepatitis A virus were not detected in any samples and rotavirus was detected in only one postpreliminary sample, these standard curves are not presented here. 
Table 5. Quality-control equipment and field-blank data for bacterial indicators, coliphage, and viruses in wastewater, 2008-10.

[qPCR, quantitative polymerase chain reaction; qRT-PCR, quantitative reverse transcriptase PCR; <, less than; --, not done; Equip, equipment; OWML, Ohio Water Microbiology Laboratory]

\begin{tabular}{|c|c|c|c|c|c|c|c|c|c|c|c|}
\hline \multirow[b]{2}{*}{$\begin{array}{l}\text { Sample } \\
\text { number }\end{array}$} & \multirow{2}{*}{$\begin{array}{l}\text { Type of } \\
\text { blank } \\
\text { sample }\end{array}$} & \multirow{2}{*}{$\begin{array}{l}\text { Plant } \\
\text { or } \\
\text { location }\end{array}$} & \multicolumn{3}{|c|}{$\begin{array}{l}\text { Bacterial indicators } \\
\text { (colony-forming units } \\
\text { per } 100 \text { milliliters) }\end{array}$} & \multicolumn{2}{|c|}{$\begin{array}{c}\text { Coliphage } \\
\text { (plaque-forming } \\
\text { units } \\
\text { per } 100 \text { milliliters) }\end{array}$} & \multicolumn{3}{|c|}{$\begin{array}{c}\text { Enteric viruses by } \\
\text { qPCR or qRT-PCR } \\
\text { (genomic copies per liter) }\end{array}$} & \multirow{2}{*}{$\begin{array}{c}\begin{array}{c}\text { Culturable } \\
\text { viruses } \\
\text { (viruses } \\
\text { per liter) }\end{array} \\
\text { Viruses }\end{array}$} \\
\hline & & & $\begin{array}{c}\text { Escherichia } \\
\text { coli }\end{array}$ & $\begin{array}{c}\text { Entero- } \\
\text { cocci }\end{array}$ & $\begin{array}{c}\text { Fecal } \\
\text { coliforms }\end{array}$ & Somatic & F-specific & $\begin{array}{l}\text { Adeno- } \\
\text { virus }\end{array}$ & $\begin{array}{l}\text { Entero- } \\
\text { virus }\end{array}$ & $\begin{array}{c}\text { Norovirus } \\
\text { GI }\end{array}$ & \\
\hline 3 & Field & 3 & $<1$ & $<1$ & $<1$ & $<1$ & $<1$ & -- & -- & -- & $<1.5$ \\
\hline 3 & Equip. & OWML & -- & -- & -- & -- & -- & $<15$ & $<90$ & $<90$ & -- \\
\hline 6 & Field & 1 & $<1$ & $<1$ & $<1$ & $<1$ & $<1$ & $<23$ & $<140$ & $<140$ & -- \\
\hline 10 & Field & 2 & -- & -- & -- & -- & -- & $<23$ & $<140$ & $<140$ & -- \\
\hline 16 & Field & 5 & $<1$ & $<1$ & $<1$ & $<1$ & $<1$ & $<23$ & $<140$ & $<140$ & $<2.0$ \\
\hline
\end{tabular}

The lowest concentration that was detected in the range of each standard curve was in the single digits for each assay; therefore, for consistency, the $\mathrm{A}_{\mathrm{LOQ}}$ was established as $1 \mathrm{gc}$. Data were then qualified on the basis of $\mathrm{Ct}, \mathrm{A}_{\mathrm{LOQ}}$, and SRL, as follows:

- If the $\mathrm{Ct}$ was less than the $\mathrm{Ct}$ associated with $1 \mathrm{gc}$, the result was reported without any qualifiers.

- If the $\mathrm{Ct}$ was greater than the $\mathrm{Ct}$ associated with $1 \mathrm{gc}$ but less than 40, the result was reported with an $\mathrm{E}$ for estimated value and $b$ value qualifier. The $b$ indicates that the result was extrapolated at the low end (past the upper $\mathrm{Ct}$ limit of the standard curve).

- If the $\mathrm{Ct}$ was greater than 40 but less than 45 , the result was reported as $<\mathrm{SRL}$ with an M for "material present but not quantified."

- If the $\mathrm{Ct}$ was greater than 45 , the result was reported as $<$ SRL.
Other qualifiers were included in the reporting of results, as follows:

- If one duplicate qPCR or qRT-PCR analysis had a Ct greater than 40 and the second duplicate had a Ct less than 40, the result associated with the less than $40 \mathrm{Ct}$ was reported with an $\mathrm{E}$ for estimated value and $\sim$ value qualifier. The $\sim$ indicates that the duplicates do not agree.

- If the calculated result (in $\mathrm{gc} / \mathrm{L}$ ) was less than the SRL because of a dilution, but still within $1 \log$ of the SRL, the result was reported with an $\mathrm{E}$ for estimated value and $b$ value qualifier. The $b$ indicates that the result was extrapolated at the low end.

- If the calculated result (in $\mathrm{gc} / \mathrm{L}$ ) was at least $1 \log$ lower than the SRL, the result was reported as $<$ SRL with an M for "material present but not quantified." 
Table 6. Quality-control concurrent replicate data for bacterial indicators and coliphage in wastewater, 2008-10.

[E. coli, Escherichia coli; $\mathrm{CFU} / \mathrm{mL}$, colony-forming units per 100 milliliters; AVLD is absolute value log 10 difference between replicate A and B; prelim, preliminary; --, not done; MBR, membrane bioreactor; <, less than; >, greater than; ND, not determined because there were two values below detection; sec, secondary; dis, disinfection; PFU/100 mL, plaque-forming units per 100 milliliters]

\begin{tabular}{|c|c|c|c|c|c|c|c|c|c|c|}
\hline \multirow{2}{*}{$\begin{array}{l}\text { Sample } \\
\text { number }\end{array}$} & \multirow{2}{*}{$\begin{array}{l}\text { Type of } \\
\text { sample }\end{array}$} & \multicolumn{3}{|c|}{$\begin{array}{c}\text { E. coli } \\
\text { (CFU/100 mL) }\end{array}$} & \multicolumn{3}{|c|}{$\begin{array}{l}\text { Enterococci } \\
\text { (CFU/100 mL) }\end{array}$} & \multicolumn{3}{|c|}{$\begin{array}{c}\text { Fecal coliforms } \\
\text { (CFU/100 mL) }\end{array}$} \\
\hline & & A & B & AVLD & A & B & AVLD & A & B & AVLD \\
\hline 9 & Post-prelim & 930,000 & $1,100,000$ & 0.07 & 410,000 & 390,000 & 0.02 & 580,000 & $1,000,000$ & 0.24 \\
\hline 10 & Post-prelim & 970,000 & $1,700,000$ & .24 & $9,200,000$ & $6,600,000$ & .14 & $3,100,000$ & $2,700,000$ & .06 \\
\hline 13 & Post-prelim & -- & -- & -- & -- & -- & -- & -- & -- & -- \\
\hline 5 & Post-MBR & 2 & 2 & .00 & $<1$ & 2 & $>.30$ & 2 & 12 & .78 \\
\hline 19 & Post-MBR & $<1$ & $<1$ & ND & $<1$ & $<1$ & ND & $<1$ & $<1$ & ND \\
\hline 16 & Post-sec & 7,700 & 6,400 & .08 & 1,100 & 1,000 & .04 & 14,000 & 8,000 & .24 \\
\hline 18 & Post-sec & 15,000 & 11,000 & .13 & 3,000 & 6,000 & .30 & 26,000 & 18,000 & .16 \\
\hline 8 & Post-dis & $<1$ & $<1$ & ND & $<1$ & $<1$ & ND & $<1$ & $<1$ & ND \\
\hline 21 & Post-dis & $<1$ & $<1$ & ND & 1 & $<1$ & $>.00$ & $<1$ & $<1$ & ND \\
\hline $\begin{array}{l}\text { Sample } \\
\text { number }\end{array}$ & $\begin{array}{l}\text { Type of } \\
\text { sample }\end{array}$ & A & B & AVLD & A & B & AVLD & & & \\
\hline 9 & Post-prelim & 9,500 & 12,000 & 0.10 & 23,000 & 25,000 & 0.04 & & & \\
\hline 10 & Post-prelim & 140,000 & 92,000 & .18 & $4,800,000$ & $4,800,000$ & .00 & & & \\
\hline 13 & Post-prelim & 120,000 & 120,000 & .00 & 150,000 & 150,000 & .00 & & & \\
\hline 5 & Post-MBR & 4 & 1 & .60 & 120 & 180 & .18 & & & \\
\hline 7 & Post-MBR & 4 & 1 & .60 & 430 & 380 & .05 & & & \\
\hline 19 & Post-MBR & $<1$ & 7 & $>.84$ & 520 & 490 & .03 & & & \\
\hline 16 & Post-sec & 11 & 14 & .10 & 470 & 280 & .22 & & & \\
\hline 18 & Post-sec & 64 & 40 & .20 & 880 & 1,000 & .06 & & & \\
\hline 8 & Post-dis & $<1$ & $<1$ & ND & $<1$ & $<1$ & ND & & & \\
\hline 21 & Post-dis & $<1$ & $<1$ & ND & 8 & 9 & .05 & & & \\
\hline
\end{tabular}


Table 7. Quality-control method test samples for coliphage in wastewater, 2008-10.

[PFU/100 mL, plaque-forming units per 100 milliliters; SAL, single-agar layer method; prelim, preliminary; sec, secondary; <, less than; MBR, membrane bioreactor; NA, not applicable because filtered was detected and direct was below detection; tert, tertiary; dis, disinfection; ND, not determined because both filtered and direct values were below detection]

\begin{tabular}{|c|c|c|c|c|c|c|c|c|c|}
\hline \multirow[b]{2}{*}{$\begin{array}{l}\text { Sample } \\
\text { number }\end{array}$} & \multirow[b]{2}{*}{$\begin{array}{l}\text { Type of } \\
\text { sample }\end{array}$} & \multicolumn{4}{|c|}{ Somatic coliphage (PFU/100 mL) } & \multicolumn{4}{|c|}{ F-specific coliphage (PFU/100 mL) } \\
\hline & & $\begin{array}{c}\text { Filtered } \\
\text { SAL }\end{array}$ & $\begin{array}{c}\text { Direct } \\
\text { SAL }\end{array}$ & $\begin{array}{l}\text { Percent } \\
\text { recovery } \\
\text { by } \\
\text { filtration }\end{array}$ & $\begin{array}{c}\text { Direct } \\
\text { EasyPhage }\end{array}$ & $\begin{array}{c}\text { Filtered } \\
\text { SAL }\end{array}$ & $\begin{array}{c}\text { Direct } \\
\text { SAL }\end{array}$ & $\begin{array}{c}\text { Percent } \\
\text { recovery } \\
\text { by } \\
\text { filtration }\end{array}$ & $\begin{array}{c}\text { Direct } \\
\text { EasyPhage }\end{array}$ \\
\hline 1 & Post-prelim & 600,000 & $2,200,000$ & 27.3 & $1,500,000$ & 28,000 & 250,000 & 11.2 & $2,100,000$ \\
\hline 2 & Post-prelim & 35,000 & 310,000 & 11.3 & 240,000 & 28,000 & 420,000 & 6.7 & $2,200,000$ \\
\hline 3 & Post-prelim & 108,000 & $3,000,000$ & 3.6 & $2,400,000$ & 4,950 & 120,000 & 4.1 & 390,000 \\
\hline 4 & Post-prelim & 7,000 & 170,000 & 4.1 & 250,000 & 1,600 & 66,000 & 2.4 & 580,000 \\
\hline 5 & Post-prelim & 28,000 & 910,000 & 3.1 & $1,800,000$ & 260,000 & $1,300,000$ & 20.0 & $5,800,000$ \\
\hline 11 & Post-prelim & 20,667 & 210,000 & 9.8 & & 320,000 & $1,900,000$ & 16.8 & \\
\hline 3 & Post-sec & 108 & 1,600 & 6.8 & 804 & 1.1 & 7 & 15.7 & 63 \\
\hline 9 & Post-sec & $<.14$ & 9 & .0 & & .028 & 3 & .9 & \\
\hline 1 & Post-MBR & 12 & 921 & 1.3 & 630 & .1 & 2 & 5.0 & 35 \\
\hline 2 & Post-MBR & $<.40$ & 80 & .0 & 14 & .02 & 4 & .5 & 3 \\
\hline 4 & Post-MBR & 9.2 & 100 & 9.2 & 58 & .13 & $<1$ & NA & 2 \\
\hline 5 & Post-MBR & 1.3 & 120 & 1.1 & 52 & .057 & 4 & 1.4 & 36 \\
\hline 5 & Post-MBR & 1.2 & 180 & .7 & & .014 & 1 & 1.4 & \\
\hline 6 & Post-MBR & 2.6 & 15 & 17.3 & & .045 & $<1$ & NA & \\
\hline 7 & Post-MBR & 2.5 & 430 & .6 & & .41 & 4 & 10.3 & \\
\hline 3 & Post-tert & 29 & 940 & 3.1 & & .37 & 7 & 5.3 & \\
\hline 12 & Post-tert & 1.5 & 600 & .3 & & .15 & 7 & 2.1 & \\
\hline 1 & Post-dis & $<.0066$ & $<1$ & ND & & $<.0066$ & $<1$ & ND & \\
\hline 2 & Post-dis & .12 & 52 & .2 & & $<.0086$ & $<1$ & ND & \\
\hline 3 & Post-dis & $<.01$ & $<1$ & ND & & $<.01$ & $<1$ & ND & \\
\hline 4 & Post-dis & 11 & 100 & 11.0 & & .11 & $<1$ & NA & \\
\hline 5 & Post-dis & $<.007$ & $<1$ & ND & & $<.007$ & $<1$ & ND & \\
\hline 6 & Post-dis & $<.0004$ & $<1$ & ND & & $<.0004$ & $<1$ & ND & \\
\hline 8 & Post-dis & $<.0004$ & $<1$ & ND & & $<.0004$ & $<1$ & ND & \\
\hline 10 & Post-dis & 28 & 1,100 & 2.5 & & .523 & 19 & 2.8 & \\
\hline
\end{tabular}


Table 8. Quality-control concurrent replicate data for enteric viruses in wastewater, 2008-10.

[gc/L, genomic copies per liter; MPN/L, most probable number per liter; AVLD is absolute value log 10 difference between replicate A and B; prelim, preliminary; <, less than; ND, not determined because there were two values below detection; E, estimated value; , PCR duplicates do not match; M, presence of material verified but not quantified; >, greater than; MBR, membrane bioreactor; sec, secondary; dis, disinfection]

\begin{tabular}{|c|c|c|c|c|c|c|c|c|c|c|c|c|c|}
\hline \multirow{2}{*}{$\begin{array}{l}\text { Sample } \\
\text { number }\end{array}$} & \multirow{2}{*}{$\begin{array}{l}\text { Type of } \\
\text { sample }\end{array}$} & \multicolumn{3}{|c|}{ Adenovirus (gc/L) } & \multicolumn{3}{|c|}{ Enterovirus (gc/L) } & \multicolumn{3}{|c|}{ Norovirus, G1 (gc/L) } & \multicolumn{3}{|c|}{ Culturable viruses (MPN/L) } \\
\hline & & A & B & AVLD & A & B & AVLD & A & B & AVLD & A & B & AVLD \\
\hline 9 & Post-prelim & 2,100 & 3,000 & 0.15 & $<5,600$ & $<5,600$ & $\mathrm{ND}$ & $<5,600$ & $<5,600$ & ND & $<8$ & $<8$ & ND \\
\hline 10 & Post-prelim & 120,000 & 430,000 & .55 & $<11,000$ & $\mathrm{E} \sim 47,000$ & $>0.63$ & $<11,000$ & $<17,000$ & ND & $<8$ & 24 & $>0.48$ \\
\hline 13 & Post-prelim & 46,000 & 32,000 & .16 & 280,000 & 300,000 & .03 & $<8,300$ & $<8,300$ & ND & 9.7 & 4.6 & .32 \\
\hline 20 & Post-prelim & 1,900 & 300 & .80 & $\mathrm{M}<560$ & $\mathrm{M}<560$ & ND & 2,200 & 790 & 0.44 & 9.0 & $<8$ & $>.05$ \\
\hline 5 & Post-MBR & $<5.3$ & $\mathrm{E} \sim .32$ & $<1.2$ & $<30$ & $\mathrm{M}<1.5$ & ND & $<30$ & $<1.5$ & ND & $<.03$ & $<.03$ & ND \\
\hline 13 & Post-MBR & 2.0 & 2.3 & .06 & 7.5 & 3.1 & .38 & $<2.7$ & $<2.6$ & ND & $<.04$ & $<.04$ & ND \\
\hline 19 & Post-MBR & $<.45$ & $<.47$ & ND & $<2.6$ & $<2.7$ & ND & $<2.6$ & $\mathrm{E} \sim 17$ & $>.82$ & $<.04$ & $<.04$ & ND \\
\hline 23 & Post-MBR & $<.47$ & $<.46$ & ND & $<2.7$ & $<2.7$ & ND & $<2.7$ & $<2.7$ & ND & $<.04$ & $<.04$ & ND \\
\hline 16 & Post-sec & $\mathrm{E} \sim 10$ & $\mathrm{E} \sim 2.8$ & .55 & $<9.4$ & $<9.3$ & ND & $<9.4$ & $<9.3$ & ND & $<.15$ & $<.15$ & ND \\
\hline 18 & Post-sec & $E \sim 68$ & $<33$ & $>.31$ & $<190$ & $<190$ & ND & $<190$ & $<190$ & ND & $<.15$ & $<.15$ & ND \\
\hline 22 & Post-sec & $<1.7$ & $\mathrm{E} \sim 16$ & $>.97$ & $<9.6$ & $<9.5$ & ND & $<9.6$ & $<9.5$ & ND & $<.15$ & $<.15$ & ND \\
\hline 8 & Post-dis & $<.45$ & $<.43$ & ND & $<2.6$ & $<2.5$ & ND & $<2.6$ & $<2.5$ & ND & $<.04$ & $<.04$ & ND \\
\hline 21 & Post-dis & $M<.46$ & $<.46$ & ND & $<2.7$ & $<2.7$ & ND & $<2.7$ & $<2.7$ & ND & $<.04$ & $<.04$ & ND \\
\hline
\end{tabular}


Table 9. Performance characteristics of quantitative polymerase chain reaction (qPCR) and reverse transcriptase qPCR (qRT-PCR) standard curves for each assay.

\begin{tabular}{lcccccc}
\hline \multicolumn{1}{c}{ Assay } & Year & Slope & y-intercept & $\mathbf{R}^{2}$ & $\begin{array}{c}\text { Dynamic range } \\
\text { (copies/qPCR reaction) }\end{array}$ & $\begin{array}{c}\text { Amplification } \\
\text { efficiency } \\
\text { (percent) }\end{array}$ \\
\hline $\begin{array}{l}\text { Adenovirus } \\
\quad \text { Subgroups C, D, F }\end{array}$ & 2008 & -3.481 & 38.87 & 0.999 & $1.42-1.42 \mathrm{E}+05$ & 94 \\
$\begin{array}{l}\text { Adenovirus } \\
\quad \text { Subgroups C, D, F }\end{array}$ & 2009 & -3.312 & 38.57 & .997 & $1.10-1.10 \mathrm{E}+05$ & 100 \\
$\begin{array}{l}\text { Adenovirus } \\
\quad \text { Subgroups C, D, F }\end{array}$ & 2010 & -2.963 & 40.07 & .990 & $1.50-1.50 \mathrm{E}+06$ & 118 \\
$\begin{array}{l}\text { Adenovirus } \\
\quad \text { Subgroup A }\end{array}$ & & & & & & \\
$\begin{array}{l}\text { Adenovirus } \\
\quad \text { Subgroup A }\end{array}$ & 2009 & -3.223 & 39.94 & .999 & $6.42-6.42 \mathrm{E}+05$ & 104 \\
$\begin{array}{l}\text { Adenovirus } \\
\quad \text { Subgroup A }\end{array}$ & 2010 & -3.009 & 39.85 & .995 & $1.20-1.20 \mathrm{E}+06$ & 115 \\
Enterovirus & & & & & & \\
Enterovirus & 2008 & -3.325 & 39.08 & .999 & $1.74-1.74 \mathrm{E}+05$ & 100 \\
Enterovirus & 2009 & -3.275 & 38.43 & .999 & $1.50-1.50 \mathrm{E}+05$ & 102 \\
Norovirus GI & 2010 & -3.177 & 38.21 & .994 & $2.85-2.85 \mathrm{E}+06$ & 106 \\
Norovirus GI & 2008 & -3.161 & 38.42 & .995 & $1.50-1.50 \mathrm{E}+04$ & 107 \\
Norovirus GI & 2009 & -3.278 & 38.04 & .993 & $1.35-1.35 \mathrm{E}+04$ & 102 \\
\hline & 2010 & -3.051 & 39.67 & .996 & $1.20-1.20 \mathrm{E}+04$ & 113 \\
\hline
\end{tabular}

\section{Quality-Control Considerations for Interpreting Bacterial-Indicator, Coliphage, and Enteric- Virus Data}

Quality-control samples were collected and analyzed for all microorganisms to aid in data interpretations. The results for bacteria, coliphage, and enteric viruses were below detection for all equipment and field blanks (table 5). Laboratory blanks for bacteria, coliphage, and viruses were all negative (data not shown). These results indicate that it was unlikely that samples were contaminated from equipment or processing procedures.

\section{Quality-Control Samples for Bacterial Indicators and Coliphage}

Concurrent replicates for bacterial indicators and coliphage are listed in table 6 and shown in figure 4, with the absolute value $\log _{10}$ differences (AVLD) calculated for each replicate pair when at least one replicate included a detection. The highest AVLDs were associated with average concentrations for replicate pairs that were less than $10 \mathrm{CFU}$ or PFU/100 mL, shown in the shaded area in figure $4 A$ and $4 B$, and were for post-MBR samples. For bacterial indicators with average concentrations less than $10 \mathrm{CFU} / 100 \mathrm{~mL}$, eight AVLD s were not determined because both replicate results were $<1 \mathrm{CFU} / 100 \mathrm{~mL}$ (table 6 ). For the four replicates pairs with average concentrations $<10 \mathrm{CFU} / 100 \mathrm{~mL}$, the AVLDs ranged from 0 to $0.78 \log \mathrm{CFU} / 100 \mathrm{~mL}$. For bacterial indicators with average concentrations $>10 \mathrm{CFU} / 100 \mathrm{~mL}$, AVLDs ranged from 0.02 to $0.30 \log$ CFU/100 mL. For coliphage with average concentrations $<10 \mathrm{PFU} / 100 \mathrm{~mL}$, three AVLDs were not determined because both replicates were $<1 \mathrm{PFU} / 100 \mathrm{~mL}$ (table 6). For the four replicate pairs with average concentrations $<10 \mathrm{PFU} / 100 \mathrm{~mL}$, AVLDs ranged from 0.05 to $>0.84 \log$ PFU/100 mL. For coliphage with average concentrations $>10 \mathrm{PFU} / 100 \mathrm{~mL}$, AVLDs ranged from 0 to $0.22 \log \mathrm{PFU} / 100 \mathrm{~mL}$. These results indicate that, when interpreting removals of bacterial indicators and coliphage in wastewater samples for samples with concentrations $<10 \mathrm{CFU}$ or PFU/100 mL, log removals less than or equal to approximately 1 may not be greater than the analytical variability. For samples $>10 \mathrm{CFU}$ or PFU/100 mL, log removals less than or equal to about 0.3 may not be greater than the analytical variability. 

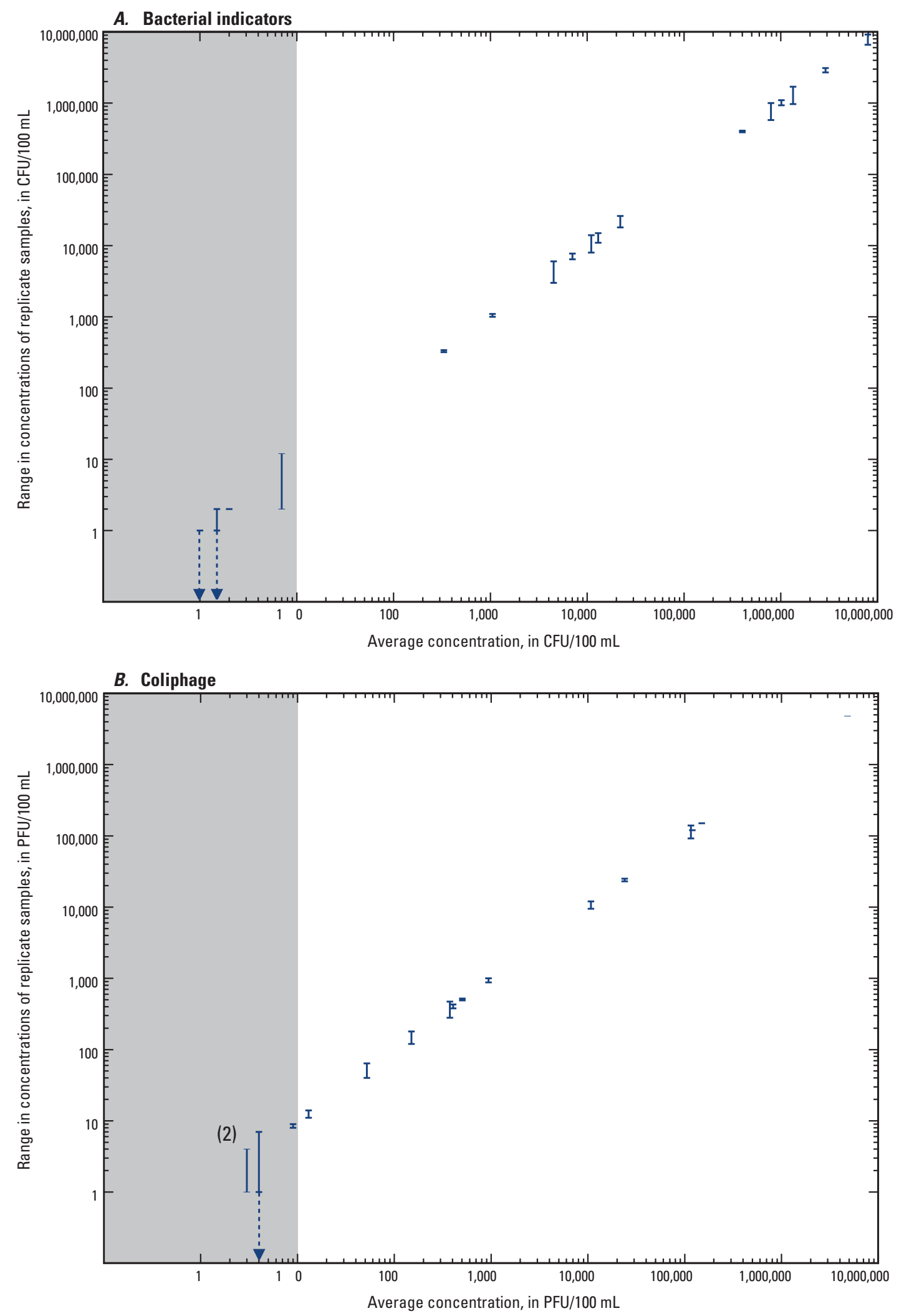

Figure 4. Quality-control replicate samples for concentrations in wastewater. $A$, bacterial indicators. $B$, coliphage.

Average concentrations less than $10 \mathrm{CFU} / 100 \mathrm{~mL}$ or PFU/100 mL are shaded in gray; if more than one replicate pair is represented by a symbol, the number of pairs is indicated. Each horizontal line represents a replicate sample volume, and the range for each replicate pair is represented by the vertical line connecting the two values. A dotted line indicates one of the replicate pairs was below detection. (Abbreviations: CFU/100 mL, colony-forming units per 100 milliliters; PFU/100 mL, plaque-forming units per 100 milliliters.) 
Results from method test samples for coliphage are listed in table 7, organized by type of wastewater sample. Concentrations of coliphage found by use of filtration and concentration (filtered SAL) can be compared to those found by use of direct plating without filtration (direct SAL). When detected, direct plating resulted in higher concentrations for all samples. In three coliphage samples, however, direct plating results were below detection $(<1 \mathrm{PFU} / 100 \mathrm{~mL}$ ) whereas filtered results were detections of $0.04,0.11$, and $0.13 \mathrm{PFU} / 100 \mathrm{~mL}$. Relative to direct plating, measurable percent recoveries in filtered samples averaged 5.7 percent for somatic coliphage and 6.7 percent for F-specific coliphage. Direct plating, therefore, is the preferred method for enumerating coliphage in wastewater samples.

Concentrations of coliphage found by use of the direct plating SAL method can be compared to the direct plating EasyPhage method. Results from the two methods were found to be highly correlated ( $\mathrm{r}=0.99$, fig. 5). For F-specific coliphage, EasyPhage resulted in higher concentrations than SAL in all but one sample (fig. $5 A$ ). For somatic coliphage, the SAL method tended to yield higher concentrations than EasyPhage in low-concentration samples (fig. $5 B$ ). The results of a Wilcoxon signed rank test (Helsel and Hirsch, 2002) showed that the median difference between paired observations was significantly different from zero for F-specific coliphage $(p=0.0059)$ but not for somatic coliphage $(p=0.3223)$. These results indicate that either the SAL or EasyPhage can be used to determine relative concentrations of coliphage in wastewater studies, if one method is chosen over the other for consistency. If actual concentrations of F-specific coliphage are needed, however, EasyPhage may be the preferred method because it yields significantly higher concentrations than the SAL method.

\section{Quality-Control Samples for Enteric Viruses}

Nine seeded matrix controls were processed and analyzed by qRT-PCR for enterovirus in the same manner as regular samples by the Marshfield Laboratory. The original seed was analyzed by qRT-PCR to determine the starting concentration of enterovirus. The Marshfield Laboratory did not find any enteroviruses in the seeded matrix controls above background concentrations. This was probably because starting concentrations, ranging from 52 to 1,100 genomic copies, were much lower than the $10^{4}$ estimated concentration from the RiboGreen assay. The source of this error is not known but may have been degradation of the virus stock and (or) inaccurate quantification. Lambertini and others (2008) found recoveries of human enteric viruses with glass-wool filters ranging from 8 to 98 percent in seeded groundwater samples. At the OWML, average recoveries from seeded lake water samples by use of glass-wool filters were 5.2 percent for adenovirus, 14.5 percent for norovirus, and 8.4 percent for enterovirus (unpublished data). These studies showed that viruses can be recovered by glass-wool filtration but that recoveries are variable. Recoveries of viruses by glass-wool filtration in wastewater samples are not documented. Plans are underway to collect and analyze a small set of seeded matrix controls for representative wastewater samples and include these results in companion reports.

Concurrent replicates for enteric viruses are listed in table 8, with the AVLDs calculated for each replicate pair and presented in figure 6 . Results for the two post-disinfection samples were not determined because either both replicates were below detection or material was present but not quantified. Many of the results for enterovirus, norovirus, and culturable viruses were similarly not determined. For some sample pairs, viruses were detected and quantified in one replicate and not detected in the other replicate. This occurred three times for adenovirus by qPCR, one time for enterovirus by qRT-PCR, one time for norovirus by qRT-PCR, and twice for culturable viruses; these instances correspond to AVLDs that are $<$ or $>$ values. Overall, concentrations among replicates were similar in magnitude with a few exceptions. In sample 10 (plant 2, post-preliminary), relatively large concentration differences were found between sample pairs for adenovirus by qPCR, enterovirus by qRT-PCR, and culturable viruses. Sample volumes were different (4.0 and $2.7 \mathrm{~L}$ ) because the filter for replicate $\mathrm{B}$ clogged and lab personnel were unable to filter the entire $4.0 \mathrm{~L}$ (table 4). The differences in molecular results between replicate pairs in sample 10 were likely due to lack of precision for samples with small effective volumes. For example, the qRT-PCR results for enterovirus of $<11,000$ and $\mathrm{E} \sim 47,000 \mathrm{gc} / \mathrm{L}$ involved a twentyfold dilution factor that resulted in very small effective volumes (0.06 and $0.09 \mathrm{~mL})$. These replicates highlight the variability of results with small effective volumes and the importance of including sample reporting limits and not just zero values in water-resource studies. Similarly, small effective volumes likely resulted in the lack of precision for culturable virus results in sample 10 and for adenovirus and norovirus results in sample 20 (plant 5, post-preliminary). Overall, the AVLDs for viruses ranged from 0 to $<1.2$ or $>0.97 \log \mathrm{gc} / \mathrm{L}$. Unlike the data for bacterial indicator and coliphage replicates, higher average virus concentrations were not associated with smaller differences in concentrations between replicates (fig. 6). These results indicate that, when interpreting removals of viruses in wastewater samples, removals less than or equal to about $1.2 \mathrm{log}$ may not be greater than the analytical variability. 

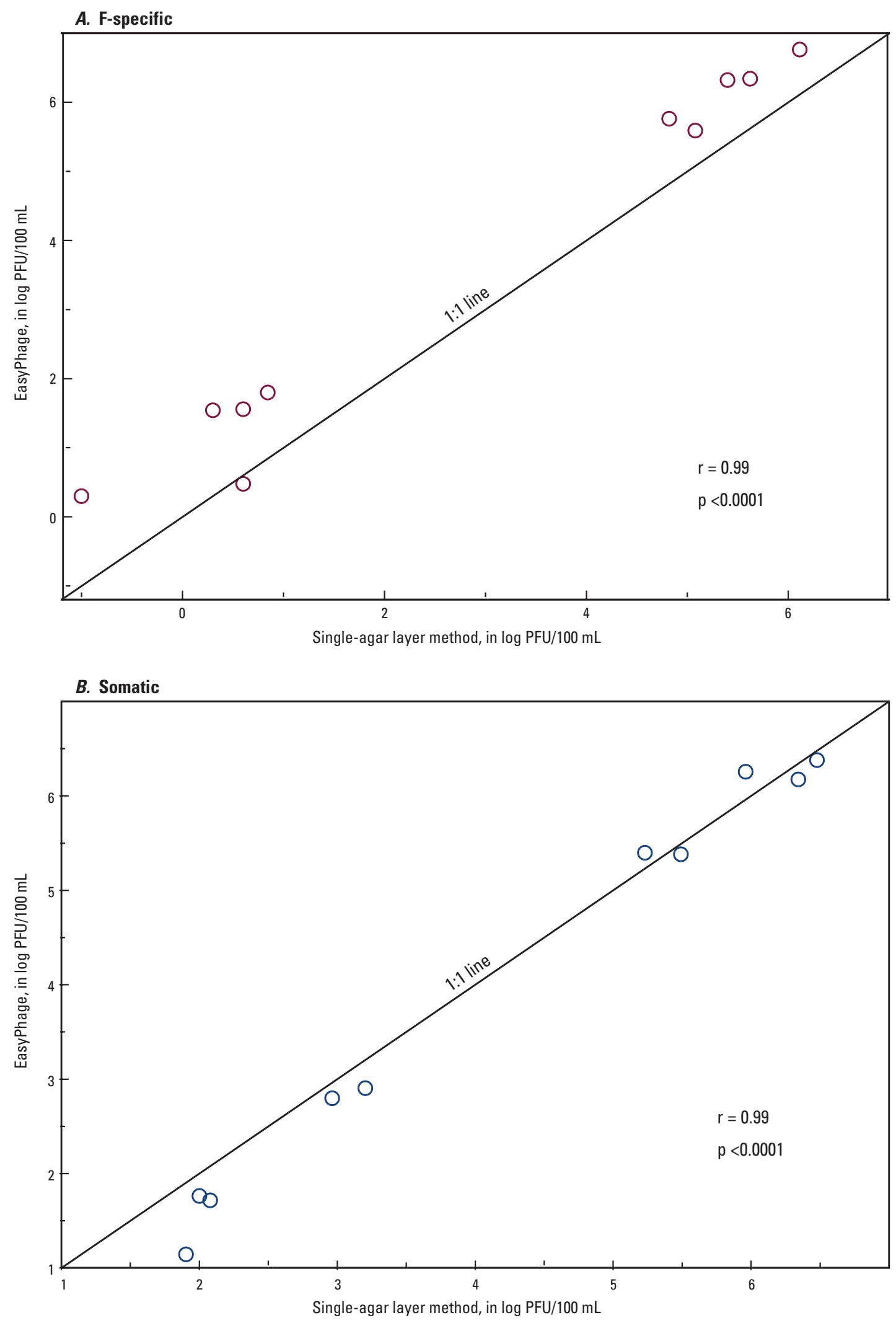

Figure 5. Concentrations found by use of the single agar layer and EasyPhage methods in wastewater samples, 2008. $A$, F-specific. $B$, somatic coliphage. (Abbreviations: PFU/100 mL, plaque-forming units per 100 milliliters; $r$ is the Pearson's correlation coefficient and $p$ is the significance of the relation.) 


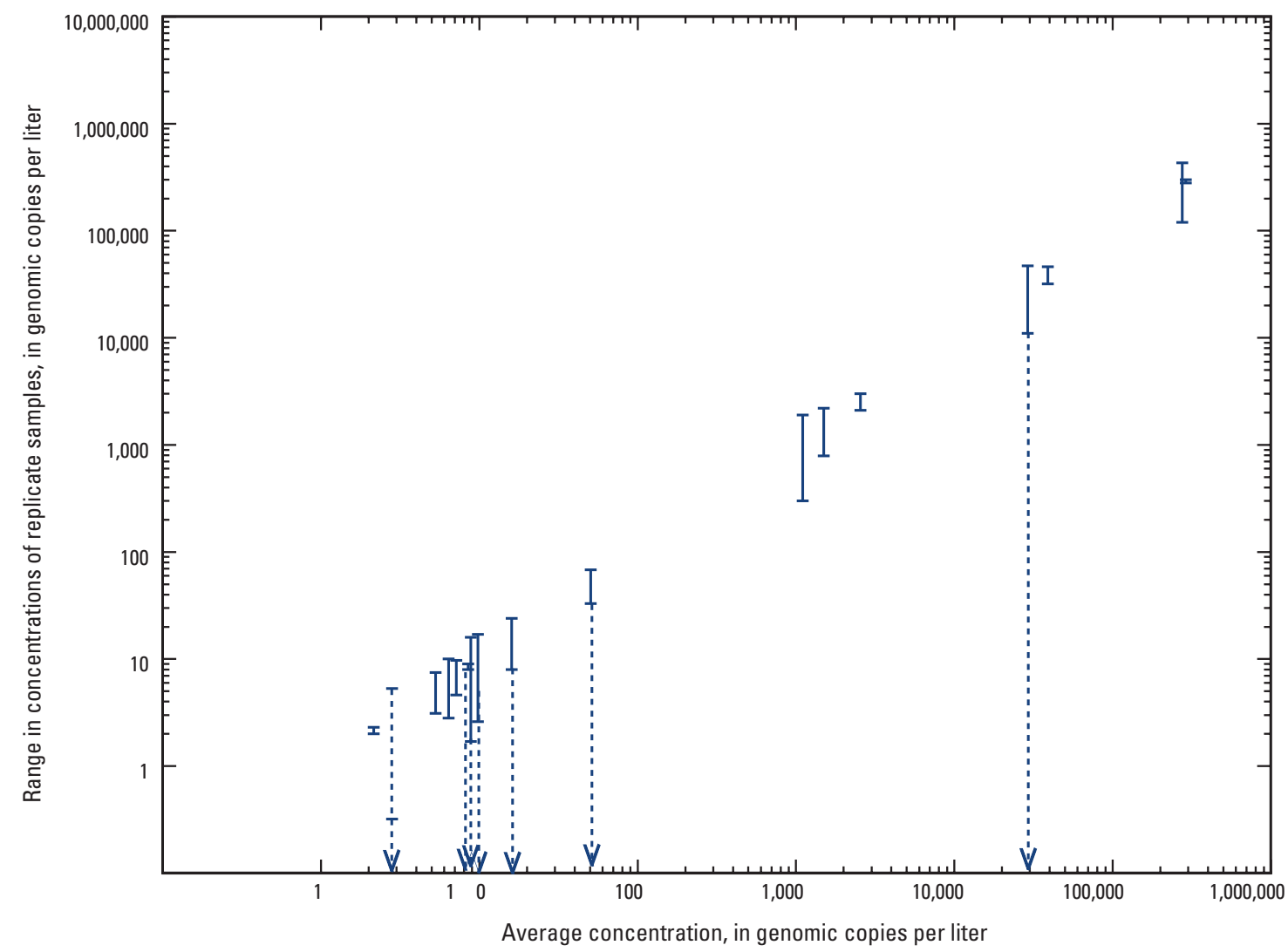

Figure 6. Quality-control replicate samples for concentrations of viruses in wastewater, 2008-10. Each horizontal line represents a replicate sample volume, and the range for each replicate pair is represented by the vertical line connecting the two values. A dotted line indicates that one of the replicate pairs was below detection.

\section{Concentrations of Bacterial Indicators and Coliphage in Wastewater}

Concentrations of $E$. coli, fecal coliforms, enterococci, and somatic and F-specific coliphage in wastewater samples are listed in table 3 and presented by plant number and type of wastewater sample in figures $7 A-E$. For each organism, results from MBR plants (1,2, and 4) and conventional plants (3 and $5)$ are presented in separate plots. Results from direct plating by the SAL method for coliphage were used for data presentations. Average concentrations from concurrent replicates for bacterial indicators and coliphage, when analyzed, were also used.

In post-preliminary wastewater samples, concentrations of $E$. coli, fecal coliforms, and enterococci were generally $10^{6}$ to $10^{7} \mathrm{CFU} / 100 \mathrm{~mL}$ with some outliers (figs. $7 A-C$ ); concentrations of somatic and F-specific coliphage showed a wider range, from $10^{4}$ to $10^{7} \mathrm{CFU} / 100 \mathrm{~mL}$ (figs. $7 D-E$ ). Among MBR plants, bacterial indicator and coliphage concentrations in post-MBR samples were highest at plant 2 . Median concentrations of bacterial indicators and coliphage in post-secondary and post-tertiary samples in conventional plants were higher than those in post-MBR samples. Median somatic coliphage concentrations were higher than F-specific coliphage concentrations in post-treatment samples, but not in post-preliminary samples. Other researchers found higher somatic coliphage than F-specific coliphage in treated wastewater samples (Zhang and Farahbakhsh, 2007). They hypothesized that F-specific coliphage tend to absorb to solid surfaces (membrane surfaces and particulate matter) more than somatic coliphage, resulting in higher removals of F-specific coliphage. In post-disinfection samples at plants 1,3 , and 4 , concentrations of bacterial indicators and coliphage were near or below the detection limit. At plants 2 and 5, however, post-disinfection sample concentrations were in the single or double digits for most samples and in the triple digits for somatic coliphage at plant 2. Plant 2 had operational issues and effluent contamination of the UV system, and plant 5 was the only chlorine disinfection system in the study. Through their NPDES permits, the wastewater plants are required to meet effluent limits for fecal coliforms (daily limit of 2,000 CFU/100 mL) and (or) E. coli (daily limit from 284-362 CFU/100 mL). All of the plants met the NPDES-required effluent limits on the days sampled for the present study. 

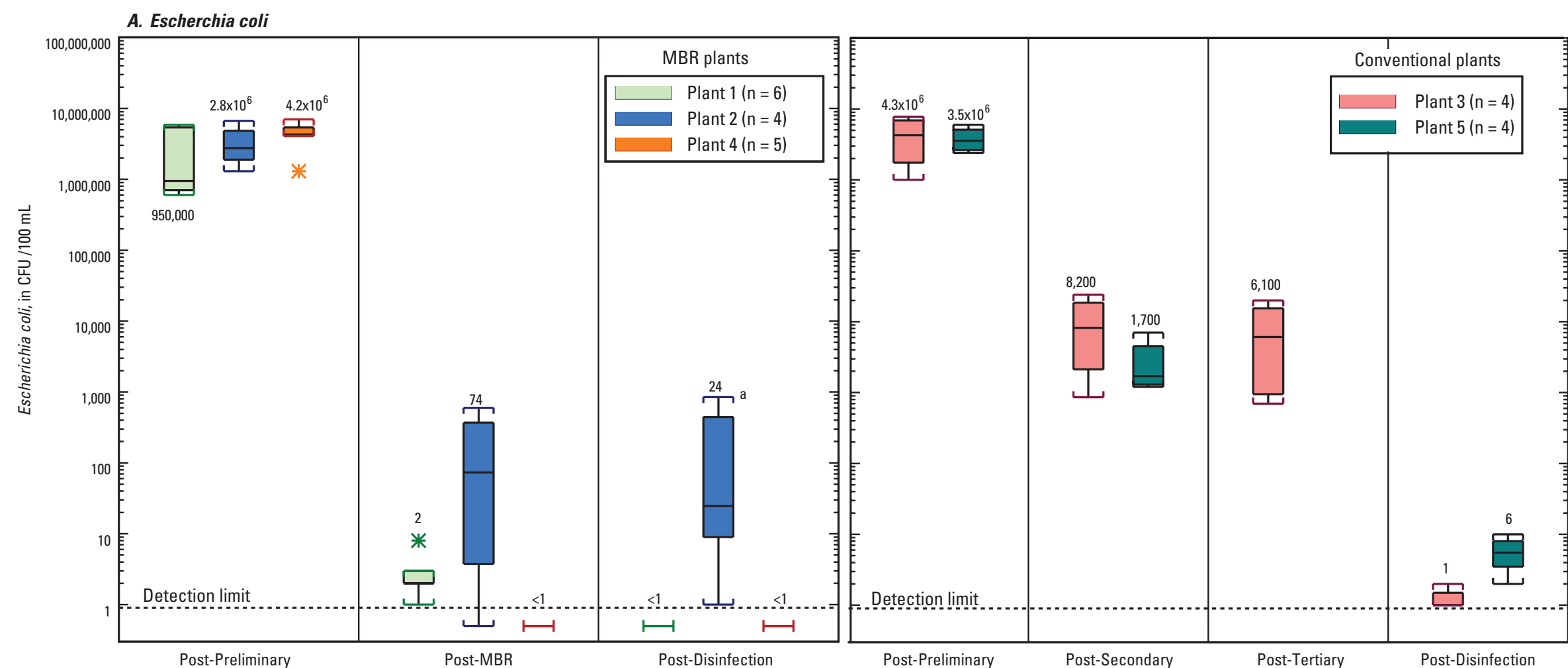

Post-Preliminary

Post-MBR

Post-Preliminary

Post-Secondary

Post-Tertiary

Post-Disinfection

EXPLANATION span.

Figure 7A. Concentrations in wastewater samples, 2008-10: Escherichia coli.

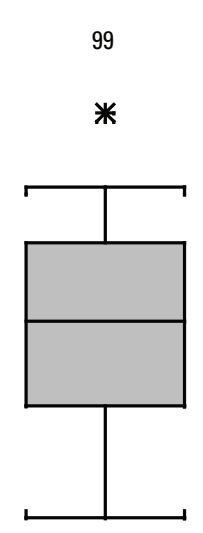

Median value
Outliers $^{2}$

Upper whisker ${ }^{1}$

75th percentile

Median

25th percentile

Lower whisker $^{1}$
${ }^{1}$ The span of the whiskers is the largest and smallest values within 1.5 times the interquartile range.

${ }^{2}$ Outliers are defined as values outside of the whisker

Median values are shown.

CFU/100 mL, colony-forming units per 100 milliliters $\mathrm{PFU} / 100 \mathrm{~mL}$, plaque-forming units per 100 milliliters MBR, membrane bioreactors

ancludes a $>32 \mathrm{CFU} / 100 \mathrm{~mL}$ value recoded as $32 \mathrm{CFU} / 100 \mathrm{~mL}$ ${ }^{b}$ Includes a $>24 \mathrm{CFU} / 100 \mathrm{~mL}$ value recoded as $24 \mathrm{CFU} / 100 \mathrm{~mL}$. ${ }^{c}$ Includes a $>80 \mathrm{CFU} / 100 \mathrm{~mL}$ value recoded as $80 \mathrm{CFU} / 100 \mathrm{~mL}$.

19ure Concentrations in wastewater samples, 2008-10: Escherichia coli. 


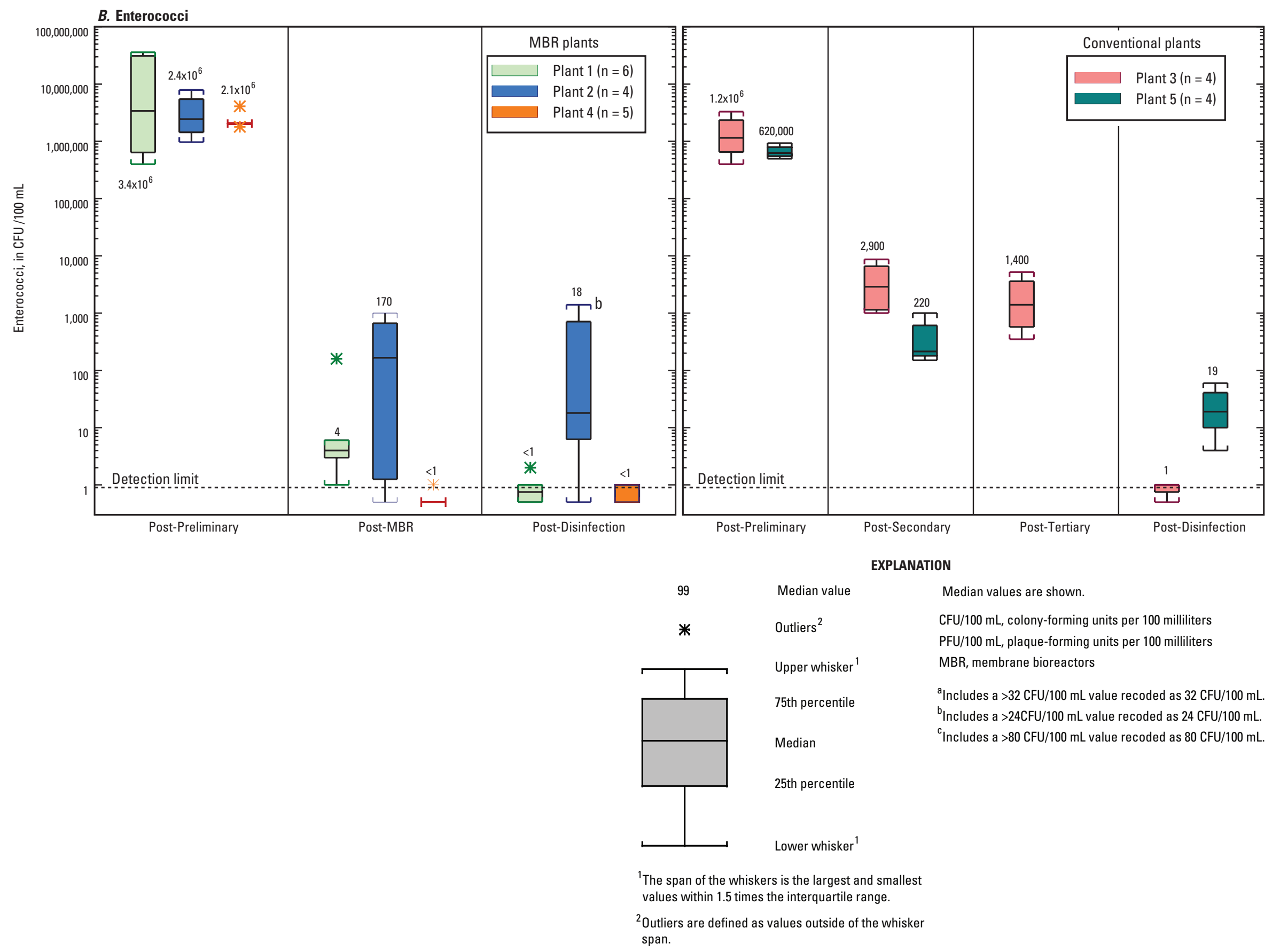

Figure 7B. Concentrations in wastewater samples, 2008-10: enterococci. 


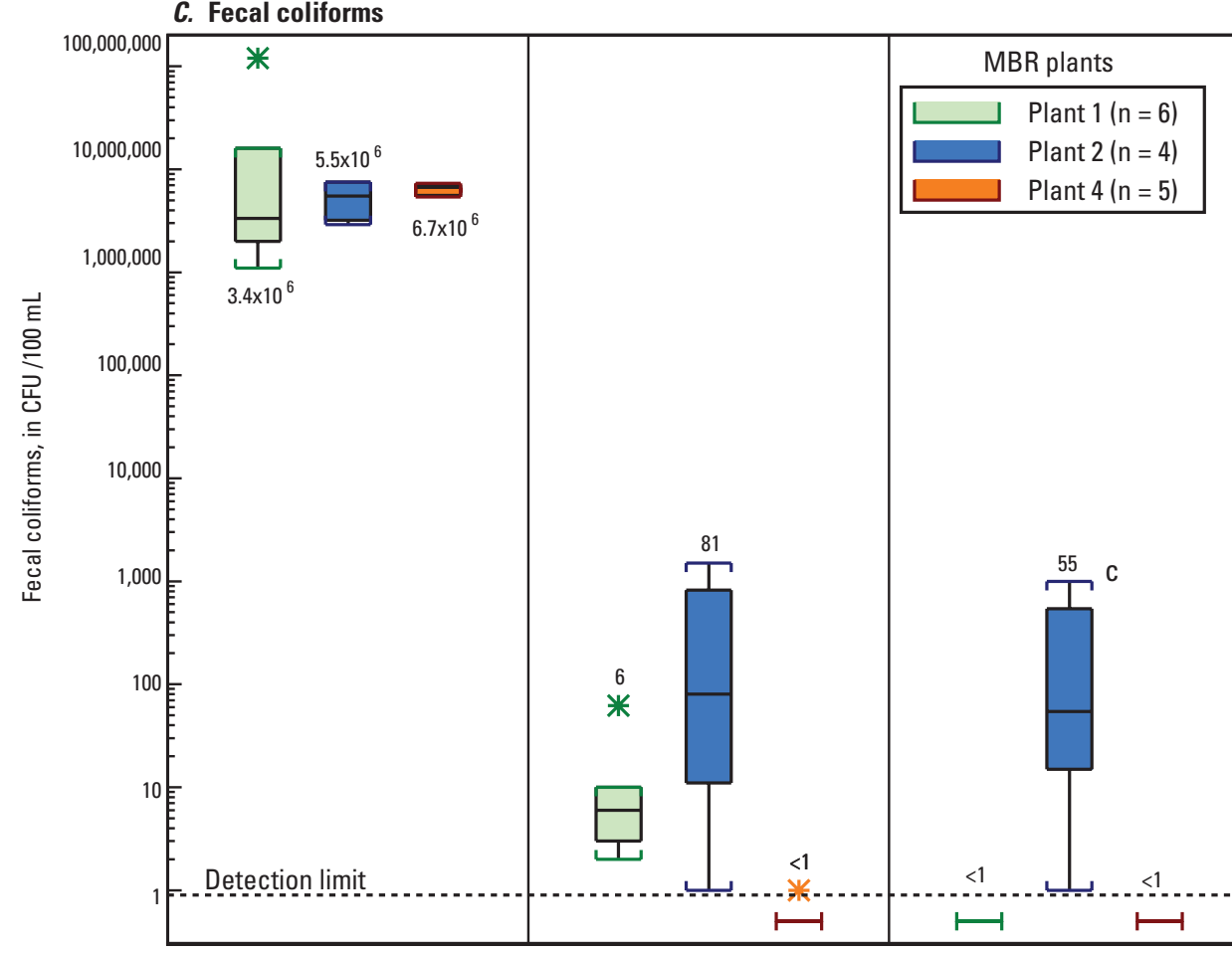

Post-Preliminary
Post-MBR
Post-

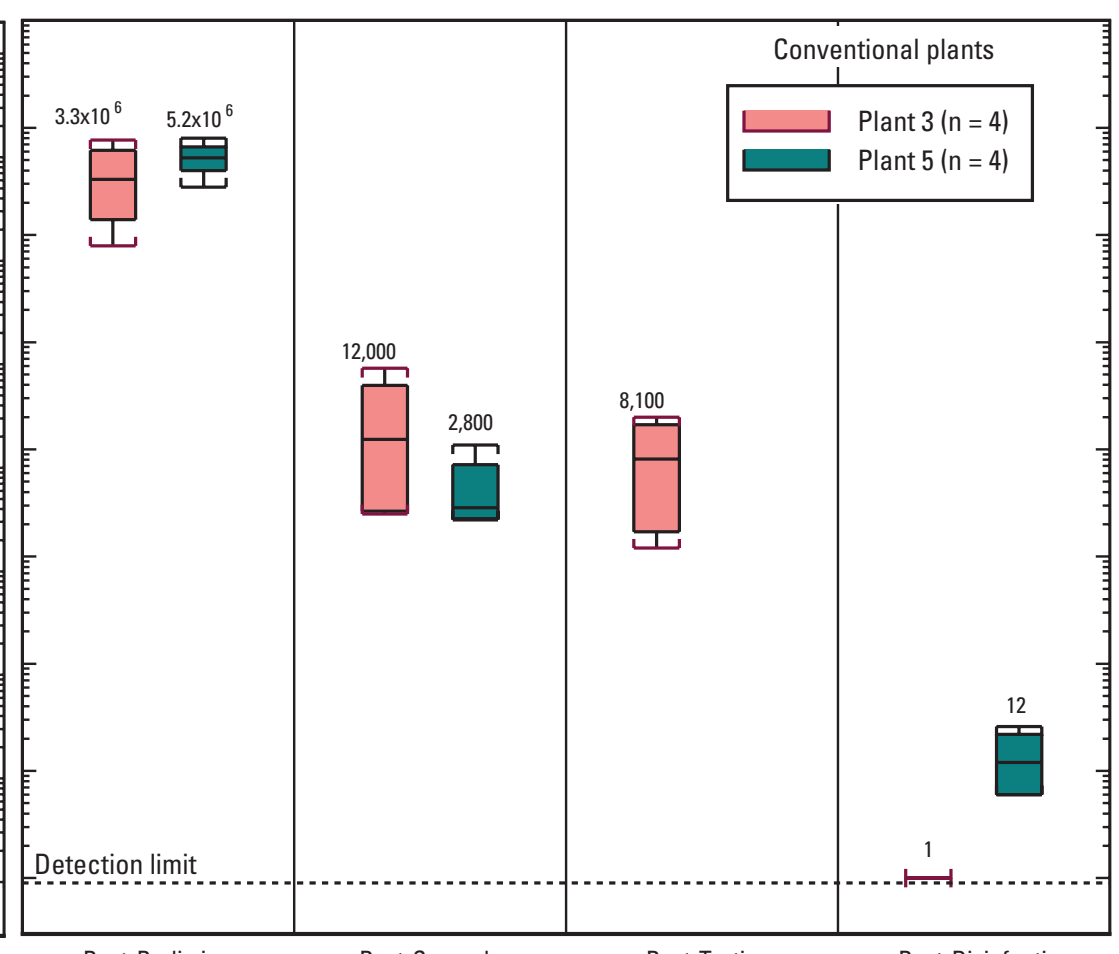

Post-Preliminary
Post-Secondary

EXPLANATION

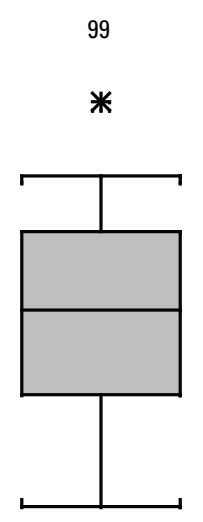

Median value

Outliers $^{2}$

Upper whisker $^{1}$

75th percentile

Median

25th percentile

\section{Lower whisker $^{1}$}

Median values are shown

$\mathrm{CFU} / 100 \mathrm{~mL}$, colony-forming units per 100 milliliters

$\mathrm{PFU} / 100 \mathrm{~mL}$, plaque-forming units per 100 milliliters

MBR, membrane bioreactors

a Includes a $>32 \mathrm{CFU} / 100 \mathrm{~mL}$ value recoded as $32 \mathrm{CFU} / 100 \mathrm{~mL}$. bIncludes a $>24 \mathrm{CFU} / 100 \mathrm{~mL}$ value recoded as $24 \mathrm{CFU} / 100 \mathrm{~mL}$.

${ }^{c}$ Includes a $>80 \mathrm{CFU} / 100 \mathrm{~mL}$ value recoded as $80 \mathrm{CFU} / 100 \mathrm{~mL}$.

${ }^{1}$ The span of the whiskers is the largest and smallest values within 1.5 times the interquartile range.

${ }^{2} 0$ utliers are defined as values outside of the whisker span.

Figure 7C. Concentrations in wastewater samples, 2008-10: fecal coliforms. 


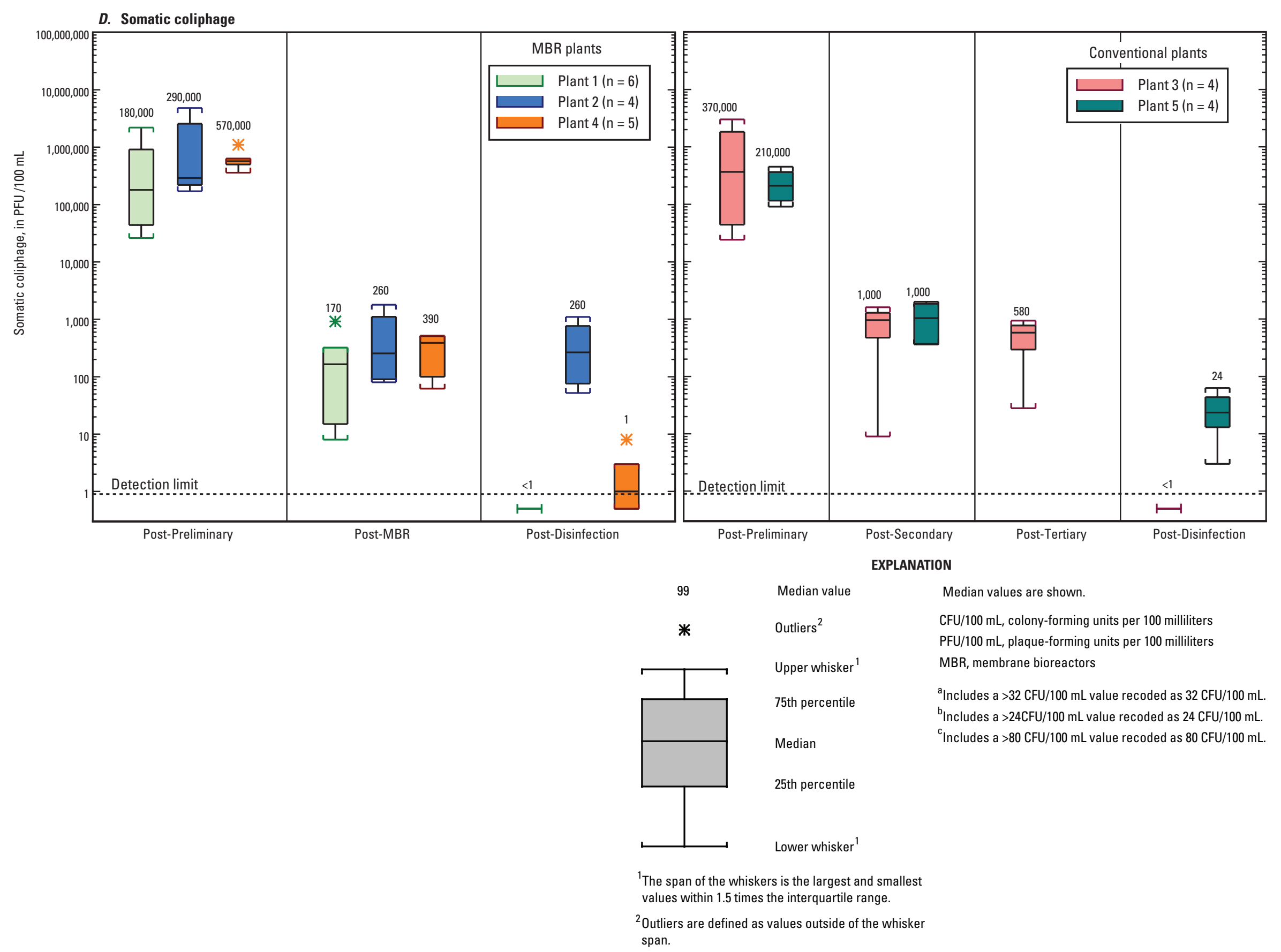

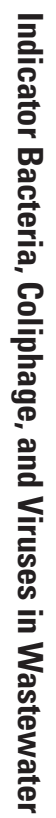

Figure 7D. Concentrations in wastewater samples, 2008-10: somatic coliphage. 


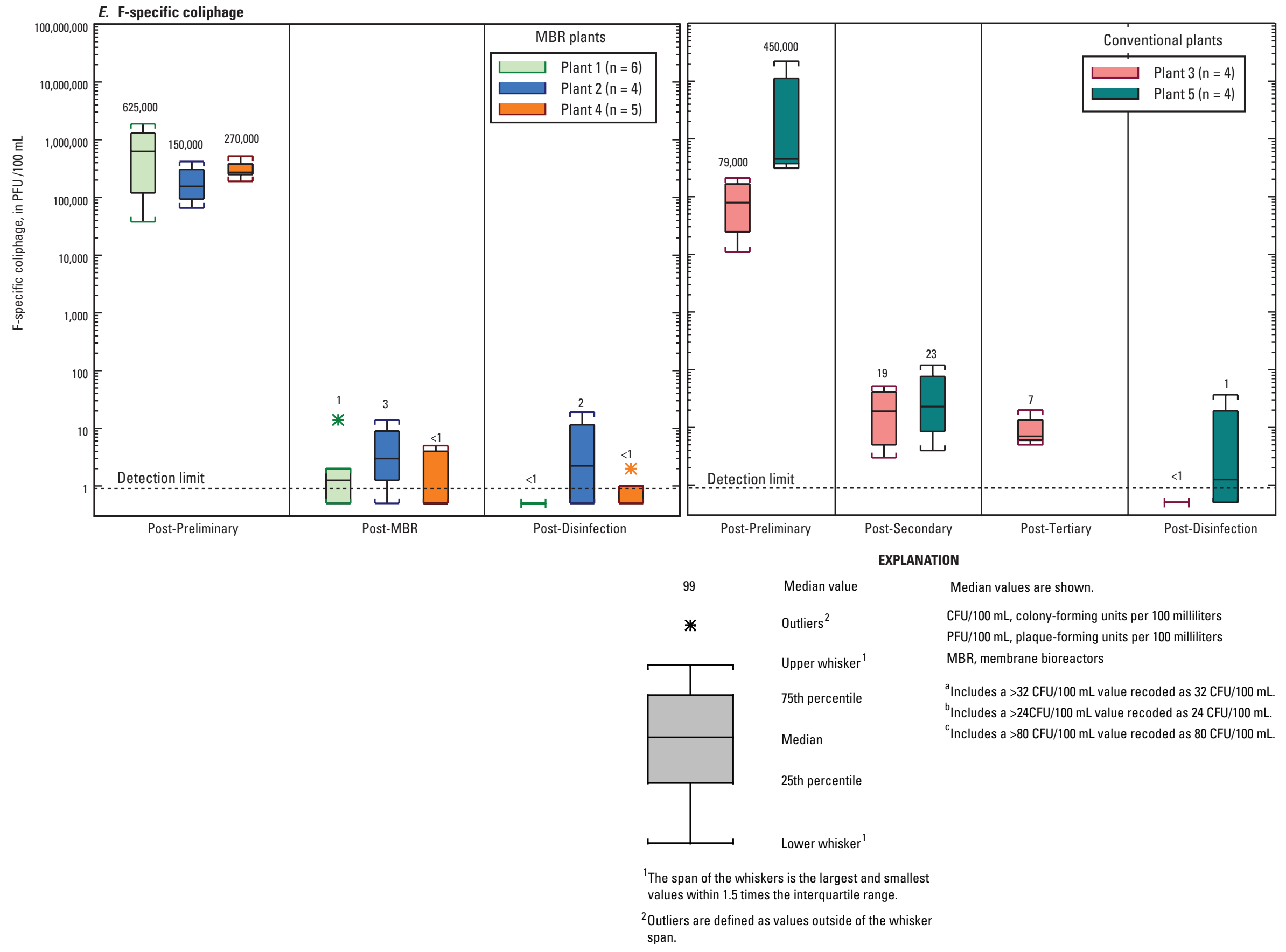

Figure 7E. Concentrations in wastewater samples, 2008-10: F-specific coliphage. 


\section{Concentrations of Enteric Viruses in Wastewater}

Concentrations for adenovirus, enterovirus, norovirus GI, and culturable viruses in wastewater samples are listed in table 4, along with effective sample volumes and the data used to calculate these values. Because norovirus GII and hepatitis A virus were not detected in any samples, and for rotavirus material was present but not quantified in one sample (sample 7, plant 2, post-preliminary), they are not included in table 4. As shown in equation 1, effective FCSV, total FCSV, original sample volume, and dilution factor were used to calculate the effective sample volumes. The effective FCSVs were specific for each assay (and year) and were calculated as shown in figure 3 for qPCR and qRT-PCR; they are listed by virus assay on the top of table 4 . Original sample volumes ranged from 2,700 to $579,700 \mathrm{~mL}$ (table 4 , column D). Total FCSVs (table 4, column E) for post-preliminary samples were $10 \mathrm{~mL}$ throughout the study; however, for other wastewater samples, FCSV volumes were $5 \mathrm{~mL}$ in 2008 and $6 \mathrm{~mL}$ in 2009 and 2010. Because of inhibition of the PCR reaction, some sample extracts were diluted by factors ranging from 5 to 20 (table 4, column F). Using equation 1 and sample number 2, plant 2, post-MBR as an example (fifth sample listed in table 4), effective sample volume for qPCR (column G) is calculated as follows:

$$
738 m L=\frac{0.0336 m L}{5 m L} * 549,400 m L * \frac{1}{5}
$$

For molecular assays, effective sample volumes ranged from $0.06 \mathrm{~mL}$ (post-preliminary samples for qRT-PCR with a dilution factor of 20) (table 4, column I) to almost 4 L (largevolume samples for qPCR that were not diluted) (table 4, column G).

As shown in equations 2-4, effective sample volumes and the $\mathrm{A}_{\mathrm{LOD}}$ were used to calculate SRLs. For the same example shown above, the SRL for qPCR is calculated by using equation 2, as follows:

$$
1.4 \mathrm{gc} / L=\frac{1 g c}{0.738 L}
$$

The SRLs were used in reporting less-than values in which viruses were not detected or in which viruses were reported with an " $\mathrm{M}$ " qualifier. The $\mathrm{M}$ indicates that viruses were present, but results cannot be quantified because of great uncertainty; this qualifier is used for both molecular and cellculture results. Less uncertainty is associated with another data qualifier for molecular results, the "E" for estimated value. The E values are quantified results, but there is still some level of uncertainty associated with the result because of two factors: the PCR duplicates did not agree (indicated with a $\sim$ ) and (or) the PCR value was extrapolated at the low end (past the upper $\mathrm{Ct}$ limit of the standard curve) (indicated with $\mathrm{a} b$ ).

Table 10 lists summary statistics for sample volumes and detections for enteric viruses grouped by plant and type of wastewater sample. The plants are combined or segregated on the basis of operational similarities and differences. Average effective sample volumes were considerably less than average original sample volumes. The smallest average effective volume was for post-preliminary samples at plant 2 for enterovirus and norovirus GI by qRT-PCR $(0.09 \mathrm{~mL})$. The largest average effective volume was for post-MBR samples at plants 1 and 4 for culturable viruses $(30,000 \mathrm{~mL})$. Adenovirus was found in 100 percent of post-preliminary samples and was detected throughout the treatment processes. Enterovirus was detected in the majority of post-preliminary samples and throughout the treatment processes except in post-disinfection samples from plant 5 , the plant with chlorine disinfection. Norovirus was detected less often than the other two enteric viruses and, in post-disinfection samples, was detected only from plant 5. Culturable viruses were detected in post-preliminary samples and 50 percent ( 2 samples) of post-MBR samples from plant 2. Cell culture results were negative in all post-secondary, post-tertiary, and post-disinfection samples. 
Table 10. Summary statistics for viruses by quantitative polymerase chain reaction (qPCR) and reverse transcriptase $q P C R$ (qRT-PCR) and cell culture in wastewater samples, 2008-10.

[Plants 1 and 4 are membrane bioreactor plants, plant 2 is a membrane bioreactor plant with operational problems, plant 3 is conventional tertiary with ultraviolet disinfection, and plant 5 is conventional secondary with chlorine disinfection; $\mathrm{mL}$, milliliters; MBR, membrane bioreactor; sec, secondary; tert, tertiary; dis, disinfection]

\begin{tabular}{|c|c|c|c|c|c|c|c|c|c|c|}
\hline \multirow[b]{2}{*}{ Plant } & \multirow[b]{2}{*}{ Type of sample } & \multirow[b]{2}{*}{$\begin{array}{l}\text { Number of } \\
\text { samples }\end{array}$} & \multirow[b]{2}{*}{$\begin{array}{c}\text { Average } \\
\text { original } \\
\text { sample } \\
\text { volume } \\
\text { (mL) }\end{array}$} & \multicolumn{3}{|c|}{$\begin{array}{l}\text { Average effective sample volumes } \\
(\mathrm{mL})\end{array}$} & \multicolumn{4}{|c|}{$\begin{array}{l}\text { Detections, including present but not quantified } \\
\text { (percent) }\end{array}$} \\
\hline & & & & $\begin{array}{l}\text { Adenovirus } \\
\text { by qPCR }\end{array}$ & $\begin{array}{c}\text { Enterovirus } \\
\text { and } \\
\text { Norovirus GI } \\
\text { by qRT-PCR }\end{array}$ & $\begin{array}{c}\text { Culturable } \\
\text { virus, } \\
\text { screening }\end{array}$ & $\begin{array}{c}\text { Adenovirus } \\
\text { by qPCR }\end{array}$ & $\begin{array}{l}\text { Enterovirus } \\
\text { by qRT-PCR }\end{array}$ & $\begin{array}{l}\text { Norovirus GI } \\
\text { by qRT-PCR }\end{array}$ & $\begin{array}{c}\text { Culturable } \\
\text { virus }\end{array}$ \\
\hline 1,4 & Post-preliminary & 12 & 3,900 & 6.0 & 1.1 & 130 & 100 & 92 & 58 & 75 \\
\hline 2 & & 5 & 3,700 & .54 & .09 & 120 & 100 & 60 & 40 & 60 \\
\hline 3,5 & & 10 & 4,000 & 6.3 & 1.1 & 130 & 100 & 60 & 50 & 40 \\
\hline 1,4 & Post-MBR & 15 & 520,000 & 2,300 & 390 & 30,000 & 40 & 20 & 13 & 0 \\
\hline 2 & & 4 & 450,000 & 1,500 & 260 & 28,000 & 75 & 75 & 25 & 50 \\
\hline 3,5 & Post-sec & 11 & 140,000 & 420 & 73 & 7,800 & 54 & 9.1 & 9.1 & 0 \\
\hline 3 & Post-tert & 4 & 480,000 & 900 & 160 & 28,000 & 50 & 25 & 0 & 0 \\
\hline 1,4 & Post-dis & 13 & 510,000 & 2,300 & 390 & 29,000 & 31 & 7.7 & 0 & 0 \\
\hline 2 & & 4 & 420,000 & 964 & 170 & 26,000 & 25 & 25 & 0 & 0 \\
\hline 3 & & 4 & 480,000 & 117 & 20 & 28,000 & 25 & 25 & 0 & 0 \\
\hline 5 & & 4 & 500,000 & 2,200 & 370 & 28,000 & 75 & 0 & 50 & 0 \\
\hline
\end{tabular}




\section{Summary}

The use of membrane bioreactor (MBR) technology for wastewater treatment is increasing in the United States. Microfiltration membranes used in wastewater treatment have a pore size large enough to theoretically reduce concentrations of protozoa and bacteria, but not viruses. There is little information, however, on the effectiveness of MBRs in removing human enteric viruses from wastewaters, particularly as compared to conventional wastewater treatment before and after disinfection. Sampling for viruses in wastewater is seldom done and not required. Instead, the bacterial indicators Escherichia coli (E. coli) and fecal coliforms are the required microbial measures of effluents for wastewater-discharge permits in Ohio and elsewhere in the United States. Bacterial indicators are used to indicate the removal of bacteria, viruses, and protozoan pathogens in wastewater.

To study the removal of viruses and indicators throughout the wastewater-treatment process, 73 regular and 28 qualitycontrol (QC) samples were collected at three MBR wastewater plants (plants 1, 2, and 4) and two conventional wastewater plants (plants 3 and 5) in Ohio. Four plants were equipped with ultraviolet disinfection, and one plant uses chlorine disinfection (plant 5). Samples were collected at various stages in the treatment processes and analyzed for enteric viruses, bacterial indicators, and coliphage. Samples were collected to compare the removal of enteric viruses, bacterial indicators, and coliphage in MBR and conventional plants and to identify whether disinfection provides further reduction of viruses after MBR. In order to address the main objectives of the study, it was quickly realized that work was needed to identify data analysis methods for interpreting enteric virus and QC data. Therefore, methods for quantifying viruses, qualifying results, and applying QC data to interpretations are described in this report; companion reports are planned to address the main objectives of the study.

During each sampling trip, samples were collected (1) before conventional or MBR treatment (post-preliminary), (2) after secondary or MBR treatment (post-MBR or postsecondary), (3) after tertiary treatment (post-tertiary, plant 3 only), and (4) after disinfection (post-disinfection). Glasswool fiber filtration was used to concentrate enteric viruses from large volumes - 4 Liter (L) for post-preliminary samples, $100 \mathrm{~L}$ for post-secondary, and $500 \mathrm{~L}$ for all other wastewater types (or 3.5 hours, whichever came first). Grab samples were collected for direct-plating analyses for bacterial indicators by membrane filtration (E. coli, fecal coliforms, enterococci) and somatic and F-specific coliphage by the single agar layer (SAL) method.

After filtration, the viruses were eluted from the filter and further concentrated. The final concentrated sample volume (FCSV) was distributed into different tubes for storage and for subsequent enteric virus analysis by use of two methods - cell culture and a molecular method, polymerase chain reaction (PCR). The cell culture method provides information on the infectivity of the viruses but does not identify specific viruses.
The PCR method for DNA viruses or reverse-transcriptase PCR (RT-PCR) for RNA viruses identifies specific viruses but does not determine infectivity. Quantitative PCR (qPCR) and quantitative RT-PCR (qRT-PCR) provide data on the level of specific viruses in a water sample and were used in this study. Samples were analyzed for culturable enteric viruses; for enterovirus, norovirus GI and GII, rotavirus, and hepatitis A virus (RNA viruses) by qRT-PCR; and for adenovirus (a DNA virus) by qPCR.

To support data interpretations, limits of quantification and detection were determined for virus results. The methods used to define these limits provide data and data qualifiers that more accurately report with confidence or lack of confidence when viruses are determined to be absent or present. Calculations for molecular assays were based on those for determining assay limits of quantification $\left(\mathrm{A}_{\mathrm{LOQ}}\right)$ and assay limits of detection $\left(\mathrm{A}_{\mathrm{LOD}}\right)$ described in Rajal and others (2007), but applied specifically for the present study. In the present study, the $A_{L O Q}$ for each molecular virus assay was near the lowest concentration that was detected in standard curves and was set to 1 genomic copy ( $\mathrm{gc}$ ) for consistency; the $\mathrm{A}_{\mathrm{LOQ}}$ was used as the $\mathrm{A}_{\mathrm{LOD}}$. For qPCR and qRT-PCR the $\mathrm{A}_{\mathrm{LOD}}$ was an estimated value, because it was not established according to established method detection limit procedures; actual sensitivity will need to be established in the future. The $\mathrm{A}_{\mathrm{LOD}}$ for cell-culture screening was 1 virus and for cell-culture most probable number (MPN) was $1.08 \mathrm{MPN}$. The $\mathrm{A}_{\mathrm{LODs}}$ were further used to determine sample reporting limits (SRLs). The SRLs were different for each sample because effective sample volumes (the volume of the original sample that was actually used in each analysis) were different for each sample. Codes were used to further qualify the virus data: (1) the $\sim$ indicated that the qPCR or qRT-PCR duplicates do not agree, (2) the b indicated that the value was extrapolated at the low end, and (3) the M indicated that material was present but not quantified.

Also to support data interpretations, considerable efforts were expended to collect and interpret field QC samples for viruses, bacterial indicators, and coliphage. These were in addition to the usual laboratory QC samples associated with each analytical method. Field QC samples for bacteria and coliphage included 3 field blanks and 10 concurrent replicates. Method test samples for coliphage were also analyzed. These included 25 filtration test samples, analyzed to provide data on recoveries of coliphage by use of glass-wool filters, and 10 EasyPhage test samples, included to test an alternative to the standard SAL method. Quality-control samples for viruses included an equipment blank, three field blanks, 13 concurrent replicates, and 9 seeded matrix controls. The blanks for bacteria, coliphage, and enteric viruses were all below detection, indicating that it was unlikely that samples were contaminated from equipment or processing procedures.

Quality-control samples for bacterial indicators and coliphage provided insights into measurement variability and method differences. The absolute value log differences (AVLDs) between concurrent replicate pairs were calculated to identify the variability associated with each measurement. 
The AVLD results indicated that for samples with concentrations $<10 \mathrm{CFU}$ or PFU/100 $\mathrm{mL}, \log$ removals less than or equal to approximately 1 may not be greater than the analytical variability. For samples $>10 \mathrm{CFU}$ or PFU/100 mL, log removals less than or equal to about 0.3 may not be greater than the analytical variability. Filtration test samples were used to compare concentrations of coliphage found by use of glass-wool filtration to concentrations found by use of direct plating without filtration. Concentrations of coliphage by filtration averaged approximately 6 percent of direct plating concentrations. The results from direct plating were used for reporting coliphage results in this report. EasyPhage test samples were compared to the direct plating SAL method. Although results from the two methods were highly correlated, concentrations of F-specific coliphage were higher with EasyPhage and concentrations of somatic coliphage were higher (for lower concentrations) with the direct plating SAL method. These results indicate that either the SAL or EasyPhage can be used to determine relative concentrations of coliphage in wastewater studies, if one method is chosen over the other for consistency. However, if actual concentrations of F-specific coliphage are needed, EasyPhage may be the preferred method because it yields significantly higher concentrations than the SAL method.

Quality-control samples for viruses were included to provide information on measurement variability and recovery efficiencies. Seeded matrix controls were collected to determine recovery of viruses through all processing and analytical steps. Unfortunately, the virus seed concentration was lower than expected, and viruses from the seed were not recovered in the FCSVs. Plans are underway to collect and analyze a small set of seeded matrix controls and include these results in companion reports. Overall, concentrations of viruses among concurrent replicate pairs were similar in magnitude with a few exceptions. Relatively large differences in molecular results for viruses between replicate pairs were likely due to lack of precision for samples with small effective volumes. These results indicate that, when interpreting removals of viruses in wastewater samples, removals less than or equal to about $1.2 \log$ may not be greater than the analytical variability.

Concentrations of $E$. coli, fecal coliform, enterococci, and somatic and F-specific coliphage were listed by sample and shown in plots. The plots included data by plant for MBR and conventional plants and by type of wastewater sample. Bacterial indicator and coliphage concentrations in post-MBR samples were highest at plant 2, which had operational issues and effluent contamination of the UV system. In post-MBR and post-secondary samples, concentrations of somatic coliphage were higher than F-specific coliphage. This may be because F-specific coliphage tend to absorb to solid surfaces more than somatic coliphage, resulting in higher removals of F-specific coliphage. In post-disinfection samples for the two MBR plants that were operating properly (plants 1 and 4) and the UV conventional plant (plant 3), concentrations for all bacterial indicators and coliphage were near or below detection. For the chlorine conventional plant (plant 5), they were in the single or double digits and for the MBR plant with operational issues (plant 2), concentrations in post-disinfection samples were as high as 1,000 PFU or CFU/100 mL. All of the plants met the NPDES required effluent limits on the days sampled.

Concentrations of adenovirus, enterovirus, norovirus GI, and culturable viruses and ancillary data used to determine those concentrations were listed by sample and detections were presented as summary statistics. Norovirus GII and hepatitis A virus were not detected in any samples, and rotavirus was present but not quantified in only one sample. Effective sample volumes (actual amount of sample that was analyzed) were much less than the original filtered sample volumes. These reductions were due to processing steps and (or) any dilutions made to minimize the effects from PCR-inhibiting substances.

Adenovirus and enterovirus were found in 100 percent and the majority of post-preliminary samples, respectively, and were detected throughout the treatment processes. Norovirus GI was detected less often than the other two enteric viruses. Culturable viruses were detected in post-preliminary samples and in only two post-MBR samples from plant 2. Cell culture results were negative in all post-secondary, post-tertiary, and post-disinfection samples.

\section{References Cited}

American Public Health Association, American Water Works Association, and Water Environment Federation, 2005, Standard methods for examination of water and wastewater (21st ed.): American Public Health Association, parts 9218, 9221, 9222 .

Ando, Tamie; Monroe, S.S.; Gentsch, J.R.; Jin, Qi; Lewis, D.C.; and Glass, R.I., 1995, Detection and differentiation of antigenically distinct small round-structured viruses (Norwalk-like viruses) by reverse transcription-PCR and southern hybridization: Journal of Clinical Microbiology, v. 33 , no. 1 , p. $64-71$.

Bofill-Mas, Silvia; Albinan-Gimenez, Nestor; Clemente-Casares, Pilar; Hundesa, Ayalkibet; Rodriguez-Manzano, Jesus; Allard, Annika; Calvo, Miquel; and Girones, Rosina, 2006, Quantification and stability of human adenoviruses and polyomavirus JCPyV in wastewater matrices: Applied and Environmental Microbiology, v. 72, no. 12, p. 7894-7896.

Britton, L.J., and Greeson, P.E., eds., 1987, Methods for collection and analysis of aquatic biological and microbiological samples: U.S. Geological Survey Techniques of WaterResources Investigations, book 5, chap. A4, p. 37-40.

Centers for Disease Control and Prevention, 2010, Viral gastroenteritis: Division of Viral Diseases, accessed November 2010 at http://www.cdc.gov/ncidod/dvrd/revb/gastro/faq. htm. 
Centers for Disease Control and Prevention, 2011, Hepitatits A information for health professionals: Division of Viral Diseases, accessed April 2011 at http://www.cdc.gov/hepatitis/ HAV/index.htm.

Cromeans, T., Narayanan, J., Jung, K., Ko, G., Wait, D., and Sobsey, M.D., 2005, Development of molecular methods to detect infectious viruses in water: Denver, Colo., American Water Works Association Research Foundation, Report No. $90995 \mathrm{~F}$.

da Silva, A.K.; Le Saux, J-C.; Parnaudeau, Sylvain; Pommepuy, Monique; Elimelech, Menachem; and Le Guyader, F.S., 2007, Evaluation of removal of noroviruses during wastewater treatment, using real-time reverse transcriptionPCR - Different behaviours of genogroups I and II: Applied and Environmental Microbiology, v. 73, p. 7891-7897.

De Leon, R., Shieh, C., Baric, R.S., and Sobsey, M.D., 1990, Detection of enteroviruses and hepatitis A virus in environmental samples by gene probes and polymerase chain reaction: Denver, Colo., American Water Works Association, Proceedings of the American Water Works Association Water Quality and Technology Conference, p. 833-853.

Francy, D.S., Bushon, R.N., Brady, A.M.G., Kephart, C.M., Stelzer, E.A., and Milam, C.M., 2010, Quality assurance/ quality control-Ohio Water Microbiology Laboratory: Accessed September 13, 2010, at http://oh.water.usgs.gov/ micro_qaqc.htm.

Francy, D.S., and Shaffer, K.H., 2008, Quality-assurance plan for water-quality activities in the USGS Ohio Water Science Center: U.S. Geological Survey Open-File Report 20081250, 73 p., available at http://pubs.usgs.gov/of/2008/1250/.

Gentsch, J.R., Glass, R.I., Woods, P., Gouvea, V., Gorziglia, M., Flores, J., Das, B.K., and Bhan, M.K., 1992, Identification of group A rotavirus gene 4 types by polymerase chain reaction: Journal of Clinical Microbiology, v. 30, no. 6, p. $1365-1373$.

Gregory, J.B., Litaker, R.W., and Noble, R.T., 2006, Rapid one-step quantitative reverse transcriptase PCR assay with competitive internal positive control for detection of enteroviruses in environmental samples: Applied and Environmental Microbiology, v. 72, no. 6, p. 3960-3967.

Haramoto, E., Katayama, H. Oguma, K., and Ohgaki, S., 2007, Quantitative analysis of human enteric adenoviruses in aquatic environments: Journal of Applied Microbiology, v. 103 , p. $2153-2159$.

Harwood, V.J.; Levin, A.D.; Scott, T.M.; Chivukula, Vasanta.; Lukasik, Jerzy; Farrah, S.R.; and Rose, J.B., 2005, Validity of the indicator organism paradigm for pathogen reduction in reclaimed water and public health protection: Applied and Environmental Microbiology, v. 71, no. 6, p. 31633170 .
He, Jian-Wen, and Jiang, Sunny, 2005, Quantification of enterococci and human adenoviruses in environmental samples by real-time PCR: Applied and Environmental Microbiology, v. 71, no. 5, p. 2250-2255.

Helsel, D.R., and Hirsch, R.M., 2002, Statistical methods in water resources: U.S. Geological Survey Techniques of Water-Resources Investigations, book 4, chap. A3, 522 p.

Jothikumar, Narayanan; Lowther, J.A.; Henshilwood, Kathleen; Lees, D.N.; Hill, V.R.; and Vinjé, Jan, 2005, Rapid and sensitive detection of noroviruses by using TaqMan-based one-step reverse transcription-PCR assays and application to naturally contaminated shellfish samples: Applied and Environmental Microbiology, v. 71, no. 4, p. 1870-1875.

Knipe, D.M., Howley, P.M., Griffin, D.E., Lamb, R.A., Martin, M.A., Roizman, B., and Straus, S.E. (eds.), 2007, Fields virology (5th ed): Philadelphia, Lippincott/Williams \& Wilkins, v. 1, p. 845-847.

Kuo, D. H.-W.; Simmons, F.J.; Blair, Scott; Hart, Elizabeth; Rose, J.B.; and Xagoraraki, Irene, 2010, Assessment of human adenovirus removal in a full-scale membrane bioreactor treating municipal wastewater: Water Research, v. 44, no. 5 , p. $1520-1530$.

Lambertini, Elisabetta; Spencer, S.K.; Bertz, P.D.; Loge, F.J.; Kieke, B.A.; and Borchardt, M.A., 2008, Concentration of enteroviruses, adenoviruses, and noroviruses from drinking water by use of glass wool filters: Applied and Environmental Microbiology, v. 74, no. 10, p. 2990-2996.

Long, S.C., and Sobsey, M.D., 2004, A comparison of the survival of F+RNA and F+DNA coliphages in lake water microcosms: Journal of Water and Health, v. 2.1, p. 15-22.

Monpoeho, S., Dehée, A., Mignotte, B., Schwartzbrod, L., Marechal, V., Nicolas, J.-C., Billaudel, S., and Férré, V., 2000, Quantification of enterovirus RNA in sludge samples using single tube real-time RT-PCR: BioTechniques, v. 29, no. 1, p. 88-93.

Rajal, V.B., McSwain, B.S., Thompson, D.E., Leutenegger, C.M., and Wuertz, S., 2007, Molecular quantitative analysis of human viruses in California stormwater: Water Research, v. 41, p. 4287-4298.

Rutjes, S.A.; Italiaander, Ronald; van den Berg, H.H.J.L.; Lodder, W.J.; and de Roda Husman, A.M., 2005, Isolation and detection of enterovirus RNA from large-volume water samples by using the NucliSens miniMAG system and real-time nucleic acid sequence-based amplification: Applied and Environmental Microbiology, v. 71, no. 7, p. 3734-3740. 
Schlueter, Volker; Schmolke, Susanne; Stark, Klaus; Hess, Georg; Ofenloch-Haehnle, Beatus; and Engel, A.M., 1996, Reverse transcription-PCR detection of hepatitis G virus: Journal of Clinical Microbiology, v. 34, no. 11, p. 26602664.

Schwab, K.J.; De Leon, Ricardo; and Sobsey, M.D., 1995, Concentration and purification of beef extract mock eluates from water samples for the detection of enteroviruses, hepatitis A virus and Norwalk virus by reverse transcription PCR: Applied and Environmental Microbiology, v. 61, no. 2, p. 531-537.

Sedmak, Gerald; Bina, David; MacDonald, Jeffrey; and Couillard, Lon, 2005, Nine-year study of the occurrence of culturable viruses in source water for two drinking water treatment plants and the influent and effluent of a wastewater treatment plant in Milwaukee, Wisconsin (August 1994 through July 2003): Applied and Environmental Microbiology, v. 71, no. 2, p. 1042-1050.

Sobsey, M.D., Amant, A., and Handzel, T., 1995, Detection and occurrence of coliphage indicator viruses in water, in Proceedings of the Water Quality Technology Conference, American Water Works Association, November 1995, New Orleans, La.: p. 2087-2097.

U.S. Environmental Protection Agency, 2001a, Method 1602-Male-specific $(\mathrm{F}+)$ and somatic coliphage in water by single agar layer (SAL) procedure: Washington D.C., Office of Water, EPA 821-R-01-029, available at http://www.epa.gov/nerlcwww/1602ap01.pdf.

U.S. Environmental Protection Agency, 2001b, USEPA Manual of methods for virology - Chapter 15: Washington D.C., Office of Research and Development, EPA 600/4-84/013, 30 p. (Also available at www.epa.gov/nerlcwww/chapt15. $p d f$.)
U.S. Environmental Protection Agency, 2006a, Method 1603-Escherichia coli in water by membrane filtration using modified membrane-thermotolerant Escherichia coli agar: Washington, D.C., EPA 821-R-06-011, 42 p. (Also available at $h t t p: / / w w w . e p a . g o v / w a t e r s c i e n c e / m e t h o d s /$ method/biological/.)

U.S. Environmental Protection Agency, 2006b, Method 1600 - Enterococci in water by membrane filtration using membrane-Enterococcus Indoxyl-b-D-Glucoside agar (mEI): Washington, D.C., EPA-821-R-06-009 [variously paged].

U.S. Environmental Protection Agency, 2010, Definition and procedure for the determination of the method detection limit-Revision 1.11: Federal Register, Title 40, Protection of the Environment, Appendix B to Part 136, accessed January 7,2010, at http://ecfr.gpoaccess.gov/.

U.S. Geological Survey, 2010, Users manual for the National Water Information System of the U.S. Geological SurveyWater quality system version 4.10, accessed December 23, 2010, at http://nwis.usgs.gov/nwisdocs4_10/qw/QW.user. book.html.

Wilde, F.D., ed., 2005 to present. Field measurements: U.S. Geological Survey Techniques of Water-Resources Investigations, book 9, chap. A6, accessed November 23, 2010, at http://water.usgs.gov/owq/FieldManual/Chapter6/ Ch6 contents.html.

Zhang, K., and Farahbakhsh, K., 2007, Removal of native coliphages and coliform bacteria from municipal wastewater by various wastewater treatment processes-Implications to water reuse: Water Research, v. 41, p. 2816-2824. 

$[\mu \mathrm{S} / \mathrm{cm}$, microsiemens per centimeter; NTRU, nephelometric turbidity reference units; E. coli, Escherichia coli; CFU/mL, colony-forming units per $100 \mathrm{milliliters;} \mathrm{PFU/100} \mathrm{mL,} \mathrm{plaque-form-}$ ing units per 100 milliliters; prelim, preliminary; K, based on non-ideal colony count; MBR, membrane bioreactor; dis, disinfection; <, less than; sec, secondary; tert, tertiary; A, average of two replicate values; >, greater than; --, not determined]

\begin{tabular}{|c|c|c|c|c|c|c|c|c|c|c|}
\hline $\begin{array}{l}\text { Sample } \\
\text { number }\end{array}$ & Plant & $\begin{array}{l}\text { Type of } \\
\text { sample }\end{array}$ & pH & $\begin{array}{c}\text { Specific } \\
\text { conductance } \\
(\mu \mathrm{S} / \mathrm{cm})\end{array}$ & $\begin{array}{l}\text { Turbidity } \\
\text { (NTRU) }\end{array}$ & $\begin{array}{c}\text { E. coli } \\
\text { (CFU/100 mL) }\end{array}$ & $\begin{array}{c}\text { Fecal } \\
\text { coliforms } \\
\text { (CFU/100 mL) }\end{array}$ & $\begin{array}{l}\text { Enterococci } \\
\text { (CFU/100 mL) }\end{array}$ & $\begin{array}{c}\text { Coliphage, } \\
\text { male-specific } \\
\text { (PFU/100 mL) }\end{array}$ & $\begin{array}{c}\text { Coliphage, } \\
\text { somatic } \\
\text { (PFU/100 mL) }\end{array}$ \\
\hline 1 & 1 & Post-prelim & 6.6 & 1,268 & 200 & $5,900,000$ & K $16,000,000$ & K $36,000,000$ & 250,000 & $2,200,000$ \\
\hline 1 & 1 & Post-MBR & 7.5 & 993 & .39 & 8 & K 62 & K 160 & 2 & 921 \\
\hline 1 & 1 & Post-dis & 7.5 & 997 & .27 & $<1$ & $<1$ & K 1 & $<1$ & $<1$ \\
\hline 2 & 2 & Post-prelim & 7.6 & 1,500 & 130 & $3,000,000$ & K 7,500,000 & $1,900,000$ & 420,000 & 310,000 \\
\hline 2 & 2 & Post-MBR & 7.7 & 3,300 & 2.8 & $<1$ & K 1 & $<1$ & 4 & 80 \\
\hline 2 & 2 & Post-dis & 7.7 & 3,300 & 1.8 & K 1 & K 1 & $<1$ & $<1$ & 52 \\
\hline 3 & 3 & Post-prelim & 7.7 & 853 & 210 & $7,800,000$ & $7,700,000$ & $1,400,000$ & 120,000 & $3,000,000$ \\
\hline 3 & 3 & Post-sec & 7.6 & 742 & 5.8 & 24,000 & 57,000 & K 8,700 & 7 & 1,600 \\
\hline 3 & 3 & Post-ter & 7.6 & 749 & 1.9 & 20,000 & 20,000 & 5,200 & 7 & 940 \\
\hline 3 & 3 & Post-dis & 7.7 & 744 & 1.8 & K 1 & K 1 & $<1$ & $<1$ & $<1$ \\
\hline 4 & 2 & Post-prelim & 7.5 & 1,503 & 130 & $2,500,000$ & $3,500,000$ & 970,000 & 66,000 & 170,000 \\
\hline 4 & 2 & Post-MBR & 7.8 & 1,350 & 1.4 & 7 & 21 & K 2 & $<1$ & 100 \\
\hline 5 & 1 & Post-prelim & 6.2 & 1,417 & 180 & $5,400,000$ & K 120,000,000 & $31,000,000$ & $1,300,000$ & 910,000 \\
\hline 5 & 1 & Post-MBR & 7.6 & 1,280 & .18 & $\mathrm{~A}, \mathrm{~K} 2$ & A 7 & $\mathrm{~A}, \mathrm{~K} 1$ & A 2 & A 150 \\
\hline 5 & 1 & Post-dis & 7.8 & 1,277 & .34 & $<1$ & $<1$ & K 2 & $<1$ & $<1$ \\
\hline 6 & 1 & Post-prelim & 6.4 & 1,120 & 85 & K 600,000 & K 1,100,000 & K 3,300,000 & 38,000 & 26,000 \\
\hline 6 & 1 & Post-MBR & 7.7 & 1,021 & .31 & K 2 & K 3 & K 3 & $<1$ & 15 \\
\hline 6 & 1 & Post-dis & 7.6 & 1,014 & .22 & $<1$ & $<1$ & $<1$ & $<1$ & $<1$ \\
\hline 7 & 2 & Post-prelim & 7.8 & 1,182 & 140 & $6,700,000$ & $7,500,000$ & $3,000,000$ & 190,000 & 270,000 \\
\hline 7 & 2 & Post-MBR & 7.6 & 1,744 & 2.2 & K 140 & 140 & A,K 330 & A 2 & A 400 \\
\hline 7 & 2 & Post-dis & 7.6 & 1,752 & 2.1 & $>32$ & $>80$ & $>24$ & 4 & 430 \\
\hline 8 & 1 & Post-prelim & 7.3 & -- & 92 & 700,000 & $2,200,000$ & 400,000 & $1,000,000$ & 44,000 \\
\hline 8 & 1 & Post-MBR & 8.2 & 952 & .50 & K 3 & 10 & K 6 & $<1$ & 8 \\
\hline 8 & 1 & Post-dis & 7.8 & 978 & .50 & $\mathrm{~A}<1$ & $\mathrm{~A}<1$ & $\mathrm{~A}<1$ & $\mathrm{~A}<1$ & $\mathrm{~A}<1$ \\
\hline 9 & 3 & Post-prelim & 8.1 & 860 & 130 & A $1,000,000$ & A 790,000 & A 400,000 & A 11,000 & A 24,000 \\
\hline 9 & 3 & Post-dis & 7.1 & 805 & .70 & K 1 & K 1 & K 1 & $<1$ & $<1$ \\
\hline
\end{tabular}


Table 3. Water-quality, bacterial indicator, and coliphage results from wastewater samples, 2008-10.-Continued

$[\mu \mathrm{S} / \mathrm{cm}$, microsiemens per centimeter; NTRU, nephelometric turbidity reference units; E. coli, Escherichia coli; $\mathrm{CFU} / \mathrm{mL}$, colony-forming units per $100 \mathrm{milliliters;} \mathrm{PFU/100} \mathrm{mL,} \mathrm{plaque-form-}$ ing units per 100 milliliters; prelim, preliminary; $\mathrm{K}$, based on non-ideal colony count; MBR, membrane bioreactor; dis, disinfection; <, less than; sec, secondary; tert, tertiary; A, average of two replicate values; >, greater than; --, not determined]

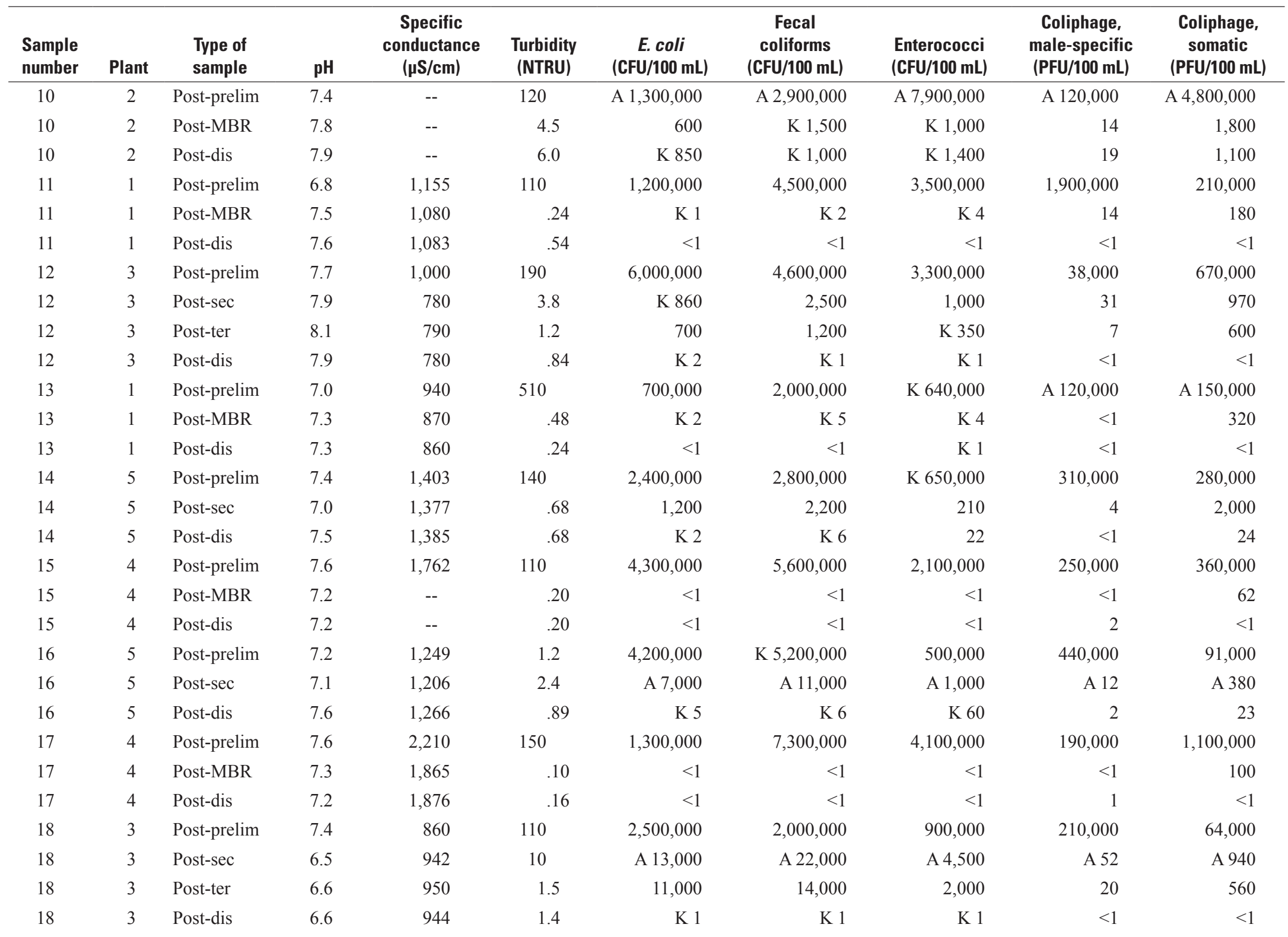


$[\mu \mathrm{S} / \mathrm{cm}$, microsiemens per centimeter; NTRU, nephelometric turbidity reference units; E. coli, Escherichia coli; $\mathrm{CFU} / \mathrm{mL}$, colony-forming units per $100 \mathrm{milliliters;} \mathrm{PFU/100} \mathrm{mL,} \mathrm{plaque-form-}$ ing units per 100 milliliters; prelim, preliminary; $\mathrm{K}$, based on non-ideal colony count; MBR, membrane bioreactor; dis, disinfection; <, less than; sec, secondary; tert, tertiary; A, average of two replicate values; >, greater than; --, not determined]

\begin{tabular}{|c|c|c|c|c|c|c|c|c|c|c|}
\hline $\begin{array}{l}\text { Sample } \\
\text { number }\end{array}$ & Plant & $\begin{array}{l}\text { Type of } \\
\text { sample } \\
\end{array}$ & $\mathrm{pH}$ & $\begin{array}{c}\text { Specific } \\
\text { conductance } \\
(\mu \mathrm{S} / \mathrm{cm})\end{array}$ & $\begin{array}{c}\text { Turbidity } \\
\text { (NTRU) }\end{array}$ & $\begin{array}{c}\text { E. coli } \\
\text { (CFU/100 mL) }\end{array}$ & $\begin{array}{c}\text { Fecal } \\
\text { coliforms } \\
\text { (CFU/100 mL) }\end{array}$ & $\begin{array}{l}\text { Enterococci } \\
\text { (CFU/100 mL) }\end{array}$ & $\begin{array}{c}\text { Coliphage, } \\
\text { male-specific } \\
\text { (PFU/100 mL) }\end{array}$ & $\begin{array}{c}\text { Coliphage, } \\
\text { somatic } \\
\text { (PFU/100 mL) }\end{array}$ \\
\hline 19 & 4 & Post-prelim & 7.4 & 2,460 & 170 & $7,000,000$ & $7,000,000$ & K 2,100,000 & 270,000 & 570,000 \\
\hline 19 & 4 & Post-MBR & 7.2 & 1,778 & .25 & $\mathrm{~A}<1$ & $\mathrm{~A}<1$ & $\mathrm{~A}<1$ & A 4 & A 500 \\
\hline 19 & 4 & Post-dis & 7.2 & 1,758 & .22 & $<1$ & $<1$ & $<1$ & $<1$ & 1 \\
\hline 20 & 5 & Post-prelim & 7.1 & 1,266 & 160 & $6,000,000$ & $8,000,000$ & 600,000 & 460,000 & 140,000 \\
\hline 20 & 5 & Post-sec & 7.0 & 1,450 & .66 & 2,000 & 3,400 & K 220 & 33 & 360 \\
\hline 20 & 5 & Post-dis & 7.6 & 1,460 & .69 & 10 & K 26 & 16 & $<1$ & 3 \\
\hline 21 & 4 & Post-prelim & 7.6 & 2,108 & 150 & $5,400,000$ & $6,700,000$ & $1,800,000$ & 380,000 & 630,000 \\
\hline 21 & 4 & Post-MBR & 7.2 & 1,802 & .20 & $<1$ & K 1 & K 1 & $<1$ & 390 \\
\hline 21 & 4 & Post-dis & 7.1 & 1,788 & .25 & $\mathrm{~A}<1$ & $\mathrm{~A}<1$ & A 1 & $\mathrm{~A}<1$ & A 8 \\
\hline 22 & 5 & Post-prelim & 7.7 & 1,440 & 150 & $2,900,000$ & $5,300,000$ & 930,000 & $22,000,000$ & 450,000 \\
\hline 22 & 5 & Post-sec & 6.9 & 1,415 & 1.1 & 1,400 & 2,300 & 150 & 120 & 1,700 \\
\hline 22 & 5 & Post-dis & 7.8 & 1,446 & .98 & K 6 & 18 & K 4 & 37 & 63 \\
\hline 23 & 4 & Post-MBR & 7.2 & 1,792 & .16 & $<1$ & $<1$ & $<1$ & 5 & 520 \\
\hline 23 & 4 & Post-dis & 7.2 & 1,796 & .12 & $<1$ & $<1$ & K 1 & 1 & 3 \\
\hline
\end{tabular}



[FCSV, final concentrated sample volume; mL, milliliter; MPN, most probable number; gc/L, genomic copies per liter; L, liter; prelim, preliminary; <, less than; MBR, membrane bioreactor; dis, disinfection; M, material present but not quantified; E, estimated value; , PCR duplicates do not agree (Ct values); b, value was extrapolated at the low end (past the upper Ct limit of the standard curve); sec, secondary]

\begin{tabular}{|c|c|c|c|c|c|c|c|c|c|c|c|c|c|}
\hline A & B & C & D & $\mathbf{E}$ & $\mathbf{F}$ & $\mathbf{G}$ & $\mathbf{H}$ & $\mathbf{I}$ & $\mathbf{J}$ & $\mathbf{K}$ & $\mathbf{L}$ & M & $\mathbf{N}$ \\
\hline & & & & & & \multicolumn{2}{|c|}{$\begin{array}{l}\text { Quantitative } \\
\text { polymerase chain } \\
\text { reaction (qPCR) }\end{array}$} & \multicolumn{3}{|c|}{$\begin{array}{l}\text { Quantitative reverse transcriptase } \\
\text { polymerase chain reaction } \\
\text { (qRT-PCR) }\end{array}$} & \multicolumn{3}{|c|}{ Culturable viruses } \\
\hline \multicolumn{6}{|c|}{ Effective FCSV } & \multicolumn{2}{|c|}{$\begin{array}{c}0.0336 \mathrm{~mL} \text { in } 2008 \\
0.0258 \mathrm{~mL} \text { in } 2009-10\end{array}$} & \multicolumn{3}{|c|}{$\begin{array}{c}0.00578 \mathrm{~mL} \text { in } 2008 \\
0.00445 \mathrm{~mL} \text { in } 2009-10\end{array}$} & \multicolumn{3}{|c|}{$\begin{array}{l}0.33 \mathrm{~mL} \text { for screening and } 0.496 \mathrm{~mL} \\
\text { for MPN }\end{array}$} \\
\hline $\begin{array}{l}\text { Sample } \\
\text { number }\end{array}$ & Plant & $\begin{array}{l}\text { Type of } \\
\text { sample }\end{array}$ & $\begin{array}{l}\text { Original } \\
\text { sample } \\
\text { volume } \\
\text { (mL) }\end{array}$ & $\begin{array}{l}\text { FCSV, } \\
\text { total } \\
\text { volume } \\
(\mathrm{mL})\end{array}$ & $\begin{array}{l}\text { Dilution } \\
\text { factor }\end{array}$ & $\begin{array}{l}\text { Effective } \\
\text { sample } \\
\text { volume } \\
\text { (mL) }\end{array}$ & $\begin{array}{l}\text { Adeno- } \\
\text { viruses } \\
\text { by qPCR } \\
\text { (gc/L) }\end{array}$ & $\begin{array}{l}\text { Effective } \\
\text { sample } \\
\text { volume } \\
\text { (mL) }\end{array}$ & $\begin{array}{l}\text { Entero- } \\
\text { viruses } \\
\text { by } \\
\text { qRT-PCR } \\
\text { (gc/L) }\end{array}$ & $\begin{array}{l}\text { Norovirus GI } \\
\text { by } \\
\text { qRT-PCR } \\
\text { (gc/L) }\end{array}$ & $\begin{array}{l}\text { Effective } \\
\text { sample } \\
\text { volume, } \\
\text { screening } \\
\text { (mL) }\end{array}$ & $\begin{array}{c}\text { Effective } \\
\text { sample } \\
\text { volume, } \\
\text { MPN } \\
\text { (mL) }\end{array}$ & $\begin{array}{l}<\text { for } \\
\text { screening } \\
\text { or MPN } \\
\text { (virus/L) }\end{array}$ \\
\hline 1 & 1 & Post-prelim & 4,000 & 10 & 1 & 13 & 540 & 2.3 & 1,700 & $<440$ & 132 & 198 & 11 \\
\hline 1 & 1 & Post-MBR & 565,000 & 5 & 1 & 3,797 & 2.0 & 653 & $<1.5$ & $<1.5$ & 37,290 & & $<0.03$ \\
\hline 1 & 1 & Post-dis & 579,000 & 5 & 1 & 3,891 & 1.6 & 669 & $<1.5$ & $<1.5$ & 38,214 & & $<0.03$ \\
\hline 2 & 2 & Post-prelim & 4,000 & 10 & 20 & 0.67 & 7,000 & 0.12 & 16,000 & $<8,300$ & 132 & 198 & 25 \\
\hline 2 & 2 & Post-MBR & 549,400 & 5 & 5 & 738 & $<1.4$ & 127 & $\mathrm{M}<7.9$ & $<7.9$ & 36,260 & 54,500 & $\mathrm{M}<0.02$ \\
\hline 2 & 2 & Post-dis & 514,000 & 5 & 1 & 3,454 & $<0.29$ & 594 & $<1.7$ & $<1.7$ & 33,924 & & $<0.03$ \\
\hline 3 & 3 & Post-prelim & 4,000 & 10 & 20 & 0.67 & 1,700 & 0.12 & $\mathrm{E} \sim \mathrm{b} 7,900$ & $<8,300$ & 132 & 198 & 69 \\
\hline 3 & 3 & Post-sec & 126,000 & 5 & 1 & 847 & $<1.2$ & 146 & $\mathrm{M}<6.8$ & $<6.9$ & 8,316 & & $<0.12$ \\
\hline 3 & 3 & Post-tert & 491,400 & 5 & 1 & 3,302 & $<0.30$ & 568 & $\mathrm{E} \sim \mathrm{b} 0.24$ & $<1.8$ & 32,432 & & $<0.03$ \\
\hline 3 & 3 & Post-dis & 485,100 & 5 & 20 & 162 & $<6.2$ & 28 & $\mathrm{M}<36$ & $<36$ & 32,017 & & $<0.03$ \\
\hline 4 & 2 & Post-prelim & 4,000 & 10 & 20 & 0.67 & 8,300 & 0.12 & E b 2,600 & $E \sim b 2,600$ & 132 & 198 & 5.2 \\
\hline 4 & 2 & Post-MBR & 499,220 & 5 & 1 & 3,355 & $\mathrm{E} \sim 1.0$ & 577 & $\mathrm{M}<1.7$ & $<1.7$ & 32,949 & 49,523 & $\mathrm{M}<0.02$ \\
\hline 4 & 2 & Post-dis & 536,520 & 5 & 20 & 180 & $<5.6$ & 31 & $\mathrm{M}<32$ & $<32$ & 35,410 & & $<0.03$ \\
\hline 5 & 1 & Post-prelim & 4,000 & 10 & 1 & 13 & 220 & 2.3 & $E \sim b 240$ & $\mathrm{E} \sim \mathrm{b} 49$ & 132 & 198 & 37 \\
\hline 5 & 1 & Post-MBR & 564,300 & 5 & 20 & 190 & $<5.3$ & 33 & $<30$ & $<30$ & 37,244 & & $<0.03$ \\
\hline 5 & 1 & $\begin{array}{l}\text { Post-MBR } \\
\text { replicate }\end{array}$ & 579,700 & 5 & 1 & 3,896 & $\mathrm{E} \sim 0.32$ & 663 & $\mathrm{M}<1.5$ & $<1.5$ & 37,851 & & $<0.03$ \\
\hline 5 & 1 & Post-dis & 573,500 & 5 & 1 & 3,854 & $\mathrm{E} \sim 0.75$ & 670 & $<1.5$ & $<1.5$ & 38,260 & & $<0.03$ \\
\hline 6 & 1 & Post-prelim & 4,000 & 10 & 5 & 2.1 & 4,600 & 0.36 & $<2,800$ & 4,200 & 132 & & $<8$ \\
\hline 6 & 1 & Post-MBR & 446,250 & 6 & 1 & 1,919 & 19 & 331 & $<3.0$ & $E \sim b 2.0$ & 24,544 & & $<0.04$ \\
\hline 6 & 1 & Post-dis & 483,000 & 6 & 1 & 2,077 & $<0.48$ & 358 & $<2.8$ & $<2.8$ & 26,565 & & $<0.04$ \\
\hline 7 & 2 & Post-prelim & 3,850 & 10 & 20 & 0.50 & $1,200,000$ & 0.09 & $<11,000$ & $\mathrm{E} \sim 9,200$ & 127 & & $<8$ \\
\hline 7 & 2 & Post-MBR & 459,000 & 6 & 1 & 1,974 & $\mathrm{E} \sim 13$ & 340 & $<2.9$ & $\mathrm{E} \sim 2.3$ & 25,245 & & $<0.04$ \\
\hline 7 & 2 & Post-dis & 406,000 & 6 & 10 & 175 & $<5.7$ & 30 & $<33$ & $<33$ & 22,330 & & $<0.04$ \\
\hline
\end{tabular}


Table 4. Virus concentrations in wastewater samples, 2008-10.-Continued

[FCSV, final concentrated sample volume; mL, milliliter; MPN, most probable number; gc/L, genomic copies per liter; L, liter; prelim, preliminary; <, less than; MBR, membrane bioreactor; dis, disinfection; M, material present but not quantified; E, estimated value; , PCR duplicates do not agree (Ct values); b, value was extrapolated at the low end (past the upper Ct limit of the standard curve); sec, secondary]

\begin{tabular}{|c|c|c|c|c|c|c|c|c|c|c|c|c|c|}
\hline A & B & C & D & $\mathbf{E}$ & $\mathbf{F}$ & G & $\mathbf{H}$ & I & $\mathbf{J}$ & $\mathbf{K}$ & $\mathbf{L}$ & M & $\mathbf{N}$ \\
\hline & & & & & & \multicolumn{2}{|c|}{$\begin{array}{l}\text { Quantitative } \\
\text { polymerase chain } \\
\text { reaction (qPCR) }\end{array}$} & \multicolumn{3}{|c|}{$\begin{array}{l}\text { Quantitative reverse transcriptase } \\
\text { polymerase chain reaction } \\
\text { (qRT-PCR) }\end{array}$} & \multicolumn{3}{|c|}{ Culturable viruses } \\
\hline \multicolumn{6}{|c|}{ Effective FCSV } & \multicolumn{2}{|c|}{$\begin{array}{c}0.0336 \mathrm{~mL} \text { in } 2008 \\
0.0258 \mathrm{~mL} \text { in } 2009-10\end{array}$} & \multicolumn{3}{|c|}{$\begin{array}{c}0.00578 \mathrm{~mL} \text { in } 2008 \\
0.00445 \mathrm{~mL} \text { in } 2009-10\end{array}$} & \multicolumn{3}{|c|}{$\begin{array}{c}0.33 \mathrm{~mL} \text { for screening and } 0.496 \mathrm{~mL} \\
\text { for MPN }\end{array}$} \\
\hline $\begin{array}{l}\text { Sample } \\
\text { number }\end{array}$ & Plant & $\begin{array}{l}\text { Type of } \\
\text { sample }\end{array}$ & $\begin{array}{l}\text { Original } \\
\text { sample } \\
\text { volume } \\
(\mathrm{mL})\end{array}$ & $\begin{array}{l}\text { FCSV, } \\
\text { total } \\
\text { volume } \\
(\mathrm{mL})\end{array}$ & $\begin{array}{l}\text { Dilution } \\
\text { factor }\end{array}$ & $\begin{array}{l}\text { Effective } \\
\text { sample } \\
\text { volume } \\
(\mathrm{mL})\end{array}$ & $\begin{array}{l}\text { Adeno- } \\
\text { viruses } \\
\text { by qPCR } \\
\text { (gc/L) }\end{array}$ & $\begin{array}{l}\text { Effective } \\
\text { sample } \\
\text { volume } \\
\text { (mL) }\end{array}$ & $\begin{array}{c}\text { Entero- } \\
\text { viruses } \\
\text { by } \\
\text { qRT-PCR } \\
\text { (gc/L) }\end{array}$ & $\begin{array}{l}\text { Norovirus GI } \\
\text { by } \\
\text { qRT-PCR } \\
\text { (gc/L) }\end{array}$ & $\begin{array}{l}\text { Effective } \\
\text { sample } \\
\text { volume, } \\
\text { screening } \\
\text { (mL) }\end{array}$ & $\begin{array}{c}\text { Effective } \\
\text { sample } \\
\text { volume, } \\
\text { MPN } \\
\text { (mL) }\end{array}$ & $\begin{array}{l}<\text { for } \\
\text { screening } \\
\text { or MPN } \\
\text { (virus/L) }\end{array}$ \\
\hline 8 & 1 & Post-prelim & 4,000 & 10 & 20 & 0.52 & 180,000 & 0.09 & $\mathrm{E} \sim 55,000$ & $<11,000$ & 132 & 198 & 21 \\
\hline 8 & 1 & Post-MBR & 529,000 & 6 & 1 & 2,275 & $\mathrm{E} \sim 6.0$ & 392 & $<2.6$ & $<2.6$ & 29,095 & & $<0.04$ \\
\hline 8 & 1 & Post-dis & 516,000 & 6 & 1 & 2,219 & $<0.45$ & 383 & $<2.6$ & $<2.6$ & 28,380 & & $<0.04$ \\
\hline 8 & 1 & $\begin{array}{l}\text { Post-dis } \\
\text { replicate }\end{array}$ & 543,000 & 6 & 1 & 2,335 & $<0.43$ & 403 & $<2.5$ & $<2.5$ & 29,865 & & $<0.04$ \\
\hline 9 & 3 & Post-prelim & 4,000 & 10 & 10 & 1.0 & 2,100 & 0.18 & $<5,600$ & $<5,600$ & 132 & & $<8$ \\
\hline 9 & 3 & $\begin{array}{l}\text { Post-prelim } \\
\text { replicate }\end{array}$ & 4,000 & 10 & 10 & 1.0 & 3,000 & 0.18 & $<5,600$ & $<5,600$ & 132 & & $<8$ \\
\hline 9 & 3 & Post-sec & 143,000 & 6 & 20 & 31 & $\mathrm{E} \sim 120$ & 5.3 & $<190$ & $<190$ & 7,865 & & $<0.15$ \\
\hline 9 & 3 & Post-tert & 504,000 & 6 & 20 & 108 & $E \sim b 6.3$ & 19 & $<53$ & $<53$ & 27,720 & & $<0.04$ \\
\hline 9 & 3 & Post-dis & 502,000 & 6 & 20 & 108 & $<9.3$ & 19 & $<53$ & $<53$ & 27,610 & & $<0.04$ \\
\hline 10 & 2 & Post-prelim & 4,000 & 10 & 20 & 0.52 & 120,000 & 0.09 & $<11,000$ & $<11,000$ & 132 & & $<8$ \\
\hline 10 & 2 & $\begin{array}{l}\text { Post-prelim } \\
\text { replicate }\end{array}$ & a2,700 & 10 & 20 & 0.35 & 430,000 & 0.06 & $\mathrm{E} \sim 47,000$ & $<17,000$ & 89 & 134 & 24 \\
\hline 10 & 2 & Post-MBR & 302,000 & 6 & 20 & 65 & 1,300 & 11 & 400 & $<91$ & 16,610 & & $<0.06$ \\
\hline 10 & 2 & Post-dis & 214,000 & 6 & 20 & 46 & $\mathrm{~Eb} 12$ & 7.9 & $<130$ & $<130$ & 11,770 & & $<0.08$ \\
\hline 11 & 1 & Post-prelim & 3,000 & 10 & 20 & 0.39 & 33,000 & 0.07 & $\mathrm{M}<14,000$ & $<14,000$ & 99 & & $<10$ \\
\hline 11 & 1 & Post-MBR & 500,890 & 6 & 1 & 2,154 & $<0.46$ & 371 & $<2.7$ & $<2.7$ & 27,549 & & $<0.04$ \\
\hline 11 & 1 & Post-dis & 501,000 & 6 & 1 & 2,154 & $<0.46$ & 372 & $<2.7$ & $<2.7$ & 27,555 & & $<0.04$ \\
\hline 12 & 3 & Post-prelim & 4,000 & 10 & 20 & 0.52 & 17,000 & 0.09 & $E \sim b 5,700$ & $E \sim b \quad 6,700$ & 132 & 198 & 10 \\
\hline 12 & 3 & Post-sec & 107,000 & 6 & 20 & 23 & $<43$ & 4.0 & $<250$ & $<250$ & 5,885 & & $<0.17$ \\
\hline 12 & 3 & Post-tert & 436,000 & 6 & 20 & 94 & $<11$ & 16 & $<63$ & $<63$ & 23,980 & & $<0.04$ \\
\hline 12 & 3 & Post-dis & 505,000 & 6 & 20 & 109 & $<9.2$ & 19 & $<53$ & $<53$ & 27,775 & & $<0.04$ \\
\hline
\end{tabular}


[FCSV, final concentrated sample volume; mL, milliliter; MPN, most probable number; gc/L, genomic copies per liter; L, liter; prelim, preliminary; <, less than; MBR, membrane bioreactor; dis, disinfection; M, material present but not quantified; E, estimated value; , PCR duplicates do not agree (Ct values); b, value was extrapolated at the low end (past the upper Ct limit of the standard curve); sec, secondary]

\begin{tabular}{|c|c|c|c|c|c|c|c|c|c|c|c|c|c|}
\hline A & B & C & D & $\mathbf{E}$ & $\mathbf{F}$ & $\mathbf{G}$ & $\mathbf{H}$ & $\mathbf{I}$ & J & $\mathbf{K}$ & $\mathbf{L}$ & M & $\mathbf{N}$ \\
\hline & & & & & & \multicolumn{2}{|c|}{$\begin{array}{l}\text { Quantitative } \\
\text { polymerase chain } \\
\text { reaction (qPCR) }\end{array}$} & \multicolumn{3}{|c|}{$\begin{array}{l}\text { Quantitative reverse transcriptase } \\
\text { polymerase chain reaction } \\
\text { (qRT-PCR) }\end{array}$} & \multicolumn{3}{|c|}{ Culturable viruses } \\
\hline \multicolumn{6}{|c|}{ Effective FCSV } & \multicolumn{2}{|c|}{$\begin{array}{c}0.0336 \mathrm{~mL} \text { in } 2008 \\
0.0258 \mathrm{~mL} \text { in } 2009-10\end{array}$} & \multicolumn{3}{|c|}{$\begin{array}{c}0.00578 \mathrm{~mL} \text { in } 2008 \\
0.00445 \mathrm{~mL} \text { in } 2009-10\end{array}$} & \multicolumn{3}{|c|}{$\begin{array}{c}0.33 \mathrm{~mL} \text { for screening and } 0.496 \mathrm{~mL} \\
\text { for MPN }\end{array}$} \\
\hline $\begin{array}{l}\text { Sample } \\
\text { number }\end{array}$ & Plant & $\begin{array}{l}\text { Type of } \\
\text { sample }\end{array}$ & $\begin{array}{l}\text { Original } \\
\text { sample } \\
\text { volume } \\
(\mathrm{mL})\end{array}$ & $\begin{array}{l}\text { FCSV, } \\
\text { total } \\
\text { volume } \\
(\mathrm{mL})\end{array}$ & $\begin{array}{c}\text { Dilution } \\
\text { factor }\end{array}$ & $\begin{array}{l}\text { Effective } \\
\text { sample } \\
\text { volume } \\
(\mathrm{mL})\end{array}$ & $\begin{array}{l}\text { Adeno- } \\
\text { viruses } \\
\text { by qPCR } \\
\text { (gc/L) }\end{array}$ & $\begin{array}{l}\text { Effective } \\
\text { sample } \\
\text { volume } \\
(\mathrm{mL})\end{array}$ & $\begin{array}{l}\text { Entero- } \\
\text { viruses } \\
\text { by } \\
\text { qRT-PCR } \\
\text { (gc/L) }\end{array}$ & $\begin{array}{l}\text { Norovirus GI } \\
\text { by } \\
\text { qRT-PCR } \\
\text { (gc/L) }\end{array}$ & $\begin{array}{l}\text { Effective } \\
\text { sample } \\
\text { volume, } \\
\text { screening } \\
\text { (mL) }\end{array}$ & $\begin{array}{c}\text { Effective } \\
\text { sample } \\
\text { volume, } \\
\text { MPN } \\
\text { (mL) }\end{array}$ & $\begin{array}{l}<\text { for } \\
\text { screening } \\
\text { or MPN } \\
\text { (virus/L) }\end{array}$ \\
\hline 13 & 1 & Post-prelim & 4,000 & 10 & 15 & 0.69 & 46,000 & 0.12 & 280,000 & $<8,300$ & 132 & 198 & 9.7 \\
\hline 13 & 1 & $\begin{array}{l}\text { Post-prelim } \\
\text { replicate }\end{array}$ & 4,000 & 10 & 15 & 0.69 & 32,000 & 0.12 & 300,000 & $<8,300$ & 132 & 198 & 4.6 \\
\hline 13 & 1 & Post-MBR & 502,000 & 6 & 1 & 2,159 & 2.0 & 372 & 7.5 & $<2.7$ & 27,610 & & $<0.04$ \\
\hline 13 & 1 & $\begin{array}{l}\text { Post-MBR } \\
\text { replicate }\end{array}$ & 518,000 & 6 & 1 & 2,227 & 2.3 & 384 & 3.1 & $<2.6$ & 28,490 & & $<0.04$ \\
\hline 13 & 1 & Post-dis & 458,000 & 6 & 1 & 1,969 & 1.7 & 340 & $M<2.9$ & $<2.9$ & 25,190 & & $<0.04$ \\
\hline 14 & 5 & Post-prelim & 4,000 & 10 & 1 & 10 & 1,500 & 1.8 & $<550$ & $<550$ & 132 & & $<8$ \\
\hline 14 & 5 & Post-sec & 153,000 & 6 & 1 & 658 & $E \sim 3.6$ & 113 & $<8.8$ & $<8.8$ & 8,415 & & $<0.15$ \\
\hline 14 & 5 & Post-dis & 502,000 & 6 & 1 & 2,159 & $<0.46$ & 372 & $<2.7$ & $<2.7$ & 27,610 & & $<0.04$ \\
\hline 15 & 4 & Post-prelim & 4,000 & 10 & 1 & 10 & 2,200 & 1.8 & 950 & $E \sim 390$ & 132 & & $<8$ \\
\hline 15 & 4 & Post-MBR & 500,000 & 6 & 1 & 2,150 & $<0.47$ & 371 & $<2.7$ & $<2.7$ & 27,500 & & $<0.04$ \\
\hline 15 & 4 & Post-dis & 501,000 & 6 & 1 & 2,154 & $<0.46$ & 372 & $<2.7$ & $<2.7$ & 27,555 & & $<0.04$ \\
\hline 16 & 5 & Post-prelim & 4,000 & 10 & 1 & 10 & 7,800 & 1.8 & $\mathrm{E} \sim 470$ & $\mathrm{M}<560$ & 132 & & $<8$ \\
\hline 16 & 5 & Post-sec & 143,000 & 6 & 1 & 615 & $\mathrm{E} \sim 10$ & 106 & $<9.4$ & $<9.4$ & 7,865 & & $<0.15$ \\
\hline 16 & 5 & $\begin{array}{l}\text { Post-sec } \\
\text { replicate }\end{array}$ & 145,600 & 6 & 1 & 626 & $\mathrm{E} \sim 2.8$ & 108 & $<9.3$ & $<9.3$ & 8,008 & & $<0.15$ \\
\hline 16 & 5 & Post-dis & 502,000 & 6 & 1 & 2,159 & 17 & 372 & $<2.7$ & $<2.7$ & 27,610 & & $<0.04$ \\
\hline 17 & 4 & Post-prelim & 4,000 & 10 & 1 & 10 & 1,200 & 1.8 & 2,300 & 2,600 & 132 & 198 & 3.9 \\
\hline 17 & 4 & Post-MBR & 540,000 & 6 & 1 & 2,322 & $<0.43$ & 400 & $<2.5$ & $<2.5$ & 29,700 & & $<0.04$ \\
\hline 17 & 4 & Post-dis & 501,000 & 6 & 20 & 108 & $<9.3$ & 19 & $<53$ & $<53$ & 27,555 & & $<0.04$ \\
\hline
\end{tabular}


Table 4. Virus concentrations in wastewater samples, 2008-10.-Continued

[FCSV, final concentrated sample volume; mL, milliliter; MPN, most probable number; gc/L, genomic copies per liter; L, liter; prelim, preliminary; <, less than; MBR, membrane bioreactor; dis, disinfection; M, material present but not quantified; E, estimated value; , PCR duplicates do not agree (Ct values); b, value was extrapolated at the low end (past the upper Ct limit of the standard curve); sec, secondary]

\begin{tabular}{|c|c|c|c|c|c|c|c|c|c|c|c|c|c|}
\hline A & B & C & D & $\mathbf{E}$ & $\mathbf{F}$ & $\mathbf{G}$ & H & I & $\mathbf{J}$ & K & $\mathbf{L}$ & M & $\mathbf{N}$ \\
\hline & & & & & & \multicolumn{2}{|c|}{$\begin{array}{l}\text { Quantitative } \\
\text { polymerase chain } \\
\text { reaction (qPCR) }\end{array}$} & \multicolumn{3}{|c|}{$\begin{array}{l}\text { Quantitative reverse transcriptase } \\
\text { polymerase chain reaction } \\
\text { (qRT-PCR) }\end{array}$} & \multicolumn{3}{|c|}{ Culturable viruses } \\
\hline \multicolumn{6}{|c|}{ Effective FCSV } & \multicolumn{2}{|c|}{$\begin{array}{c}0.0336 \mathrm{~mL} \text { in } 2008 \\
0.0258 \mathrm{~mL} \text { in } 2009-10\end{array}$} & \multicolumn{3}{|c|}{$\begin{array}{c}0.00578 \mathrm{~mL} \text { in } 2008 \\
0.00445 \mathrm{~mL} \text { in 2009-10 }\end{array}$} & \multicolumn{3}{|c|}{$\begin{array}{c}0.33 \mathrm{~mL} \text { for screening and } 0.496 \mathrm{~mL} \\
\text { for MPN } \\
\end{array}$} \\
\hline $\begin{array}{l}\text { Sample } \\
\text { number }\end{array}$ & Plant & $\begin{array}{l}\text { Type of } \\
\text { sample }\end{array}$ & $\begin{array}{l}\text { Original } \\
\text { sample } \\
\text { volume } \\
(\mathrm{mL})\end{array}$ & $\begin{array}{l}\text { FCSV, } \\
\text { total } \\
\text { volume } \\
(\mathrm{mL})\end{array}$ & $\begin{array}{l}\text { Dilution } \\
\text { factor }\end{array}$ & $\begin{array}{l}\text { Effective } \\
\text { sample } \\
\text { volume } \\
\text { (mL) }\end{array}$ & $\begin{array}{l}\text { Adeno- } \\
\text { viruses } \\
\text { by qPCR } \\
\text { (gc/L) }\end{array}$ & $\begin{array}{l}\text { Effective } \\
\text { sample } \\
\text { volume } \\
\text { (mL) }\end{array}$ & $\begin{array}{c}\text { Entero- } \\
\text { viruses } \\
\text { by } \\
\text { qRT-PCR } \\
\text { (gc/L) }\end{array}$ & $\begin{array}{l}\text { Norovirus GI } \\
\text { by } \\
\text { qRT-PCR } \\
\text { (gc/L) }\end{array}$ & $\begin{array}{l}\text { Effective } \\
\text { sample } \\
\text { volume, } \\
\text { screening } \\
\text { (mL) }\end{array}$ & $\begin{array}{c}\text { Effective } \\
\text { sample } \\
\text { volume, } \\
\text { MPN } \\
\text { (mL) }\end{array}$ & $\begin{array}{l}<\text { for } \\
\text { screening } \\
\text { or MPN } \\
\text { (virus/L) }\end{array}$ \\
\hline 18 & 3 & Post-prelim & 4,000 & 10 & 1 & 10 & 560 & 1.8 & 2,200 & $<560$ & 132 & 198 & 6.1 \\
\hline 18 & 3 & Post-sec & 140,000 & 6 & 20 & 30 & $\mathrm{E} \sim 68$ & 5.2 & $<190$ & $<190$ & 7,700 & & $<0.15$ \\
\hline 18 & 3 & $\begin{array}{l}\text { Post-sec } \\
\quad \text { replicate }\end{array}$ & 141,500 & 6 & 20 & 30 & $<33$ & 5.2 & $<190$ & $<190$ & 7,783 & & $<0.15$ \\
\hline 18 & 3 & Post-tert & 502,000 & 6 & 20 & 108 & $\mathrm{E} \sim 17$ & 19 & $<53$ & $<53$ & 27,610 & & $<0.04$ \\
\hline 18 & 3 & Post-dis & 412,000 & 6 & 20 & 89 & $E \sim 39$ & 15 & $<67$ & $<67$ & 22,660 & & $<0.04$ \\
\hline 19 & 4 & Post-prelim & 3,480 & 10 & 20 & 0.45 & $\mathrm{E} \sim 21,000$ & 0.08 & 27,000 & 18,000 & 115 & 173 & 6.9 \\
\hline 19 & 4 & Post-MBR & 520,000 & 6 & 1 & 2,236 & $<0.45$ & 386 & $<2.6$ & $<2.6$ & 28,600 & & $<0.04$ \\
\hline 19 & 4 & $\begin{array}{r}\text { Post-MBR } \\
\text { replicate }\end{array}$ & 500,000 & 6 & 1 & 2,150 & $<0.47$ & 371 & $<2.7$ & $\mathrm{E} \sim 17$ & 27,500 & & $<0.04$ \\
\hline 19 & 4 & Post-dis & 502,000 & 6 & 1 & 2,159 & $<0.46$ & 372 & $<2.7$ & $<2.7$ & 27,610 & & $<0.04$ \\
\hline 20 & 5 & Post-prelim & 4,000 & 10 & 1 & 10 & 1,900 & 1.8 & $\mathrm{M}<560$ & 2,200 & 132 & 198 & 9.0 \\
\hline 20 & 5 & $\begin{array}{l}\text { Post-prelim } \\
\text { replicate }\end{array}$ & 4,000 & 10 & 1 & 10 & 300 & 1.8 & $M<560$ & 790 & 132 & & $<8$ \\
\hline 20 & 5 & Post-sec & 140,400 & 6 & 1 & 604 & $\mathrm{M}<1.7$ & 104 & $<9.6$ & $\mathrm{E} \sim 10$ & 7,722 & & $<0.15$ \\
\hline 20 & 5 & Post-dis & 500,000 & 6 & 1 & 2,150 & $\mathrm{E} \sim \mathrm{b} 0.2$ & 371 & $<2.7$ & $\mathrm{E} \sim \mathrm{b} 1.8$ & 27,500 & & $<0.04$ \\
\hline 21 & 4 & Post-prelim & 4,000 & 10 & 1 & 10 & 2,300 & 1.8 & 18,000 & $E \sim 4,000$ & 132 & 198 & 163 \\
\hline 21 & 4 & Post-MBR & 501,700 & 6 & 1 & 2,157 & $<0.46$ & 372 & $<2.7$ & $<2.7$ & 27,594 & & $<0.04$ \\
\hline 21 & 4 & Post-dis & 501,700 & 6 & 1 & 2,157 & $\mathrm{M}<0.46$ & 372 & $<2.7$ & $<2.7$ & 27,594 & & $<0.04$ \\
\hline 21 & 4 & $\begin{array}{l}\text { Post-dis } \\
\text { replicate }\end{array}$ & 501,700 & 6 & 1 & 2,157 & $<0.46$ & 372 & $<2.7$ & $<2.7$ & 27,594 & & $<0.04$ \\
\hline
\end{tabular}


Table 4. Virus concentrations in wastewater samples, 2008-10.-Continued

[FCSV, final concentrated sample volume; mL, milliliter; MPN, most probable number; gc/L, genomic copies per liter; L, liter; prelim, preliminary; <, less than; MBR, membrane bioreactor; dis, disinfection; M, material present but not quantified; E, estimated value; , PCR duplicates do not agree (Ct values); b, value was extrapolated at the low end (past the upper Ct limit of the standard curve); sec, secondary]

\begin{tabular}{|c|c|c|c|c|c|c|c|c|c|c|c|c|c|}
\hline A & B & C & D & $\mathbf{E}$ & $\mathbf{F}$ & $\mathbf{G}$ & $\mathbf{H}$ & I & J & $\mathbf{K}$ & $\mathbf{L}$ & $\mathbf{M}$ & $\mathbf{N}$ \\
\hline & & & & & & \multicolumn{2}{|c|}{$\begin{array}{l}\text { Quantitative } \\
\text { polymerase chain } \\
\text { reaction (qPCR) }\end{array}$} & \multicolumn{3}{|c|}{$\begin{array}{l}\text { Quantitative reverse transcriptase } \\
\text { polymerase chain reaction } \\
\text { (qRT-PCR) }\end{array}$} & \multicolumn{3}{|c|}{ Culturable viruses } \\
\hline \multicolumn{6}{|c|}{ Effective FCSV } & \multicolumn{2}{|c|}{$\begin{array}{c}0.0336 \mathrm{~mL} \text { in } 2008 \\
0.0258 \mathrm{~mL} \text { in 2009-10 }\end{array}$} & \multicolumn{3}{|c|}{$\begin{array}{c}0.00578 \mathrm{~mL} \text { in } 2008 \\
0.00445 \mathrm{~mL} \text { in } 2009-10\end{array}$} & \multicolumn{3}{|c|}{$\begin{array}{c}0.33 \mathrm{~mL} \text { for screening and } 0.496 \mathrm{~mL} \\
\text { for MPN }\end{array}$} \\
\hline $\begin{array}{l}\text { Sample } \\
\text { number }\end{array}$ & Plant & $\begin{array}{l}\text { Type of } \\
\text { sample }\end{array}$ & $\begin{array}{l}\text { Original } \\
\text { sample } \\
\text { volume } \\
(\mathrm{mL})\end{array}$ & $\begin{array}{l}\text { FCSV, } \\
\text { total } \\
\text { volume } \\
\text { (mL) }\end{array}$ & $\begin{array}{l}\text { Dilution } \\
\text { factor }\end{array}$ & $\begin{array}{l}\text { Effective } \\
\text { sample } \\
\text { volume } \\
\text { (mL) }\end{array}$ & $\begin{array}{l}\text { Adeno- } \\
\text { viruses } \\
\text { by qPCR } \\
\text { (gc/L) }\end{array}$ & $\begin{array}{l}\text { Effective } \\
\text { sample } \\
\text { volume } \\
\text { (mL) }\end{array}$ & $\begin{array}{c}\text { Entero- } \\
\text { viruses } \\
\text { by } \\
\text { qRT-PCR } \\
\text { (gc/L) }\end{array}$ & $\begin{array}{l}\text { Norovirus GI } \\
\text { by } \\
\text { qRT-PCR } \\
\text { (gc/L) }\end{array}$ & $\begin{array}{l}\text { Effective } \\
\text { sample } \\
\text { volume, } \\
\text { screening } \\
\text { (mL) }\end{array}$ & $\begin{array}{c}\text { Effective } \\
\text { sample } \\
\text { volume, } \\
\text { MPN } \\
\text { (mL) }\end{array}$ & $\begin{array}{l}<\text { for } \\
\text { screening } \\
\text { or MPN } \\
\text { (virus/L) }\end{array}$ \\
\hline 22 & 5 & Post-prelim & 4,000 & 10 & 1 & 10 & 670 & 1.8 & $<560$ & $E \sim b 230$ & 132 & & $<8$ \\
\hline 22 & 5 & Post-sec & 140,400 & 6 & 1 & 604 & $<1.7$ & 104 & $<9.6$ & $<9.6$ & 7,722 & & $<0.15$ \\
\hline 22 & 5 & $\begin{array}{l}\text { Post-sec } \\
\text { replicate }\end{array}$ & 142,000 & 6 & 1 & 611 & $\mathrm{E} \sim 16$ & 105 & $<9.5$ & $<9.5$ & 7,810 & & $<0.15$ \\
\hline 22 & 5 & Post-dis & 501,500 & 6 & 1 & 2,156 & $\mathrm{E} \sim 3$ & 372 & $<2.7$ & $\mathrm{M}<2.7$ & 27,583 & & $<0.04$ \\
\hline 23 & 4 & Post-prelim & 4,000 & 10 & 1 & 10 & 2,200 & 1.8 & 6,800 & $\mathrm{E} \sim 2,200$ & 132 & 198 & 12 \\
\hline 23 & 4 & Post-MBR & 500,000 & 6 & 1 & 2,150 & $<0.47$ & 371 & $<2.7$ & $<2.7$ & 27,500 & & $<0.04$ \\
\hline 23 & 4 & $\begin{array}{l}\text { Post-MBR } \\
\text { replicate }\end{array}$ & 501,700 & 6 & 1 & 2,157 & $<0.46$ & 372 & $<2.7$ & $<2.7$ & 27,594 & & $<0.04$ \\
\hline 23 & 4 & Post-dis & 502,000 & 6 & 1 & 2,159 & $<0.46$ & 372 & $<2.7$ & $<2.7$ & 27,610 & & $<0.04$ \\
\hline
\end{tabular}

a Only 2,700 $\mathrm{mL}$ was filtered because the filter clogged and was no longer able to operate. 


\section{Glossary}

The terms included in this section were specifically defined for use in this report.

Absolute value log difference (AVLD) The AVLD was determined by calculating the absolute value of the difference between concentration results for two replicate wastewater samples that were $\log 10$ transformed.

Assay limit of detection (ALOD) The ALOD is the lowest concentration of virus that can reasonably be detected with some certainty. For the present study, the ALOD was based on the ALOQ and set at 1 genomic copy (gc) for molecular assays, 1 virus for cell-culture screening analysis, and 1.08 most probable number (MPN) for cell culture MPN analysis.

Assay limit of quantification (ALO0) The ALOQ is the lowest concentration of virus that can reasonably be quantified with some certainty. For the present study, the ALOQ was set at 1 genomic copy (gc) for molecular assays (based on extrapolating standard curves), 1 virus for the cell-culture screening assay (equivalent to one cytopathic effect), and 2.18 most probable number (MPN) for the cell-culture MPN assay (calculated from MPN tables).

Cell culture A technique used to detect infectious enteric viruses in water samples. Mammalian cells are inoculated with sample and then observed for cytological changes that indicate virus growth.

Crossing threshold (Ct) The point at which a fluorescent signal crosses an established threshold during qPCR.

Cytopathic effect (CPE) Cell disintegration or changes in cell morphology that result in a positive result in the cell culture method for enteric viruses.

Deoxyribose nucleic acid (DNA) Molecule that contains the genetic instructions for most living organisms. In this report, DNA is the genetic material for adenovirus.

Effective sample volume (Veffective) The actual amount of original sample volume that was used for each virus assay. Effective sample volumes were a small proportion of the original sample volumes and were limited by processing steps for each assay.

Equipment blank A blank solution used to determine potential contamination from the cleaning and sterilization processes. Equipment blanks are processed in a controlled environment, such as in the laboratory.
Field blank A blank solution used to determine potential contamination during all steps of sample collection, transport, and processing. Field blanks are similar to equipment blanks except they are processed under actual field conditions and transported to the lab along with environmental samples.

Final concentrated sample volume (FCSV) The resultant volume of sample analyzed for viruses after filtration, elution, and concentration.

Field concurrent replicates Environmental samples collected and analyzed in a manner such that the samples are thought to be virtually identical in composition. Concurrent replicates are collected to determine sampling and (or) analytical variability.

Laboratory blank A blank solution used to determine potential contamination from equipment and processing procedures in the laboratory.

Membrane bioreactor (MBR) A wastewater-treatment technology in which secondary treatment is accomplished by submerging membranes in the conventional activated sludge tank to physically separate the solids from the liquid and filter the wastewater through the membrane.

Method test samples Replicate samples analyzed by use of two or more different processing or analytical methods.

Most probable number (MPN) A method for obtaining quantitative data from presence/absence results. Statistical MPN tables were used to determine MPNs of viruses in cell culture.

Post-disinfection Samples of final effluents collected after ultraviolet disinfection or after chlorination and dechlorination, but before being discharged to the receiving stream.

Post-MBR Samples at membrane bioreactor (MBR) plants collected after the water is filtered through the membrane filtration equipment, but before disinfection.

Post-preliminary Samples after preliminary treatment, which may include treatment processes such as influent pumping, screening, primary treatment, grit and grease removal, and (or) fine screening.

Post-secondary Samples at the conventional plants that were collected after the gravity separation accomplished by the final clarifiers. 
Post-tertiary Samples of the effluent of tertiary treatment. For this study, only one plant used tertiary treatment (in this case, sand filtration).

Quantitative polymerase chain reaction (qPCR) A technique used to amplify DNA many orders of magnitude so that it can be detected and quantified. This method was used to detect adenovirus in wastewater samples.

Quantitative reverse transcriptase polymerase chain reaction (qRT-PCR) A technique used to convert RNA to DNA and then magnify DNA many orders of magnitude so that it can be detected and quantified. This method was used to detect enterovirus, norovirus, rotavirus, and hepatitis A virus in wastewater samples.

Ribose nucleic acid (RNA) Molecule that contains the genetic instructions for some viruses, including the enteroviruses and noroviruses included in this study.
Sample reporting limit (SRL) The SRLs are the "less-than values" or the limits of detection for each sample and assay. For viruses, the SRLs were sample- and assay-specific because original sample volumes and dilutions were different for each sample and processing steps for different for each assay.

Seeded matrix controls Wastewater samples seeded with target organisms before processing or analysis. Seeded matrix controls are collected to determine recoveries of organisms through processing and analytical steps.

Single agar layer method (SAL) A method used to enumerate somatic and F-specific coliphage in water by adding the sample to a bacterial culture with molten agar and observing plaque formation after 24 hours of incubation. A plaque is a clearing in the lawn of cells where coliphages are present. 



,

